\title{
A survey of Lepturinae Latreille, 1802 (Coleoptera: Cerambycidae) of the south- eastern Baltic region (Lithuania and the Kaliningrad Region)
}

\author{
Vytautas Tamutis ${ }^{1,2^{*}}$, \\ Vitalii Alekseev ${ }^{3,4}$ \\ ${ }^{1 *}$ Kaunas T. Ivanauskas Zoological Museum, \\ Laisves al. 106, 44253 Kaunas, Lithuania \\ ${ }^{2}$ Vytautas Magnus University, \\ Kaunas Botanical Garden, \\ Ž. E. Žilibero St. 6, \\ 46324 Kaunas, Lithuania \\ ${ }^{3}$ Shirshov Institute of Oceanology, \\ Russian Academy of Sciences, \\ Nakhimovskii prospekt 36, \\ 117997 Moscow, Russia \\ ${ }^{4}$ Kaliningrad Regional Amber Museum, \\ Marshal Vasilevskii Square 1, \\ Kaliningrad 236016, Russia
}

\begin{abstract}
The paper presents the first review of the composition and distribution of the species Lepturinae Latreille, 1802 subfamily (Coleoptera: Cerambycidae) in the south-eastern Baltic region. A total of more than 3,000 records have been analyzed and more than 4,600 specimens collected since 1888 have been examined. The subfamily is confirmed to be represented by four tribes, 26 genera, and 38 species in the region. Previous records (published notifications) of seven species - Alosterna ingrica (Baeckmann), Brachyta interrogationis russica (Herbst), Euracmaeops marginatus (F.), Gnathacmaeops pratensis (Laichart.), Pachytodes erraticus (Dalman), Rhagium bifasciatum F. and Stictoleptura v. variicornis (Dalman) - were not confirmed in the region. The information on the distribution, frequency, and some features of ecology and zoogeography of 51 species found and expected to be found in the region is confirmed and detailed in the paper. Local temporal and geographical distributions of 36 species are mapped.
\end{abstract}

Keywords: Lepturinae, Cerambycidae, Lithuania, Kaliningrad Region, annotated catalogue, faunistic review

https://orcid.org/0000-0003-4390-5443

\section{INTRODUCTION}

The longhorn beetles of the Lepturinae subfamily possess specific morphological features and lifestyle. The adults are morphologically characterized by elytra somewhat tapering posteriorly, a head strongly constricted posteriorly with usually well-presented, angulate temples, and relatively short antennae with a small, spherical sec-

\footnotetext{
*Corresponding author. Email: dromius@yahoo.com
}

ond antennomere. Its stridulatory apparatus of mesonotum usually possesses a medial furrow, and the pronotum is in most cases bell-shaped (tapering anteriorly), with rounded or spined lateral sides. Unlike the majority of other representatives of the family that demonstrate nocturnal activity, most species of Lepturinae (especially Lepturini) are diurnal active flower visitors (Schapker, 2017). The larvae of Lepturinae are regarded as typical decomposers due to their development in dead and in most cases decaying and rotting wood. These 
longhorn beetles are not wood or tree pests and many of them are included in the IUNC European Red List of Saproxylic Beetles (Cálix et al., 2018) or other lists of protected species (e.g. Ødegaard et al., 2010; Ljungberg, 2015). At the same time, it should be pointed out that no representatives of Lepturinae are included in the current Red Data Books of LT or KR.

The subfamily Lepturinae is a comparatively medium-sized group of longhorn beetles. However, its taxonomy still remains controversial (e.g. Dutrillaux, Dutrillaux, 2018; Zamorka et al., 2019). The subfamily comprises about 1,500 species distributed mainly in the Holarctic Realm (Schapker, 2017), which are grouped in 11 tribes worldwide in modern classification (Bousquet et al., 2009; Danilevsky, 2019). The representatives of four tribes (Oxymirini, Rhamnusiini, Rhagiini, and Lepturini) inhabit the studied area.

This group of longhorn beetles is well studied in most European countries; however, knowledge about these beetles in the south-eastern Baltic region [Lithuania (LT) and the Kaliningrad Region (KR)] is still poor and in most cases fragmented. There are only few papers (exclusively faunistic) devoted to Cerambycidae in this region (Zawadzki, 1937; Staniulisówna, 1939; Pileckis, 1958; Pileckis, Monsevičius, 1997; Alekseev, Sakhnov, 2002; Alekseev, 2007). Some scarce records of more interesting species are scattered in numerous faunistic papers or short communications (e.g. Ferenca, 2003; Inokaitis, 2009; Ivinskis et al., 2009; Alekseev, Bukejs, 2014; Alekseev et al., 2015; Tamutis, Martinaitis, 2019). Forty-six species (44 species for LT and 36 for KR) of the subfamily are listed as representatives of local fauna in check-lists of the species (Alekseev, 2007; Tamutis et al., 2011) according to the local data and notes of some additional species of Cerambycidae for the region in some well-known lists and catalogues (e.g. Bercio, Folwaczny, 1979; Sama, Löbl, 2010). However, the actual faunistic data and specifics of the distribution of most species in the region have been insufficiently published or not published at all. Moreover, the situation for some species, especially those whose distri- bution ranges may be expanding across the territory (Rhagium bifasciatum, Pachyta lamed, Brachyta interrogationis, etc.), is unclear.

Like other saproxylic beetles, almost all representatives of Lepturinae play an important role in the wood decomposition process and food chains in forested areas. However, intensifying forest management and modernisation of parks in urban territories have decreased the available dead wood habitat for these beetles (Seibold et al., 2014). Lepturinae is polyphagous for most of its larval stage but usually prefers 1-2 tree hosts. The availability of dead wood substrate is a critical factor for these beetles. They could, therefore, be indicative of biodiversity of forest ecosystem. That is why today this comprehensive review, based on a critical analysis of previously published information and re-examination of collected material, is more important than ever before.

The aim of our study was a critical summarization of all published and unpublished faunistic information, with a compilation of an annotated catalogue and distribution maps of the species of Lepturinae that occur in the south-eastern Baltic region. Also, we considered it useful to include brief information on the biology and the general distribution of the subfamily as well as to comment on some of the faunistic peculiarities of the taxa.

\section{MATERIALS AND METHODS}

All available data on the records of Lepturinae from Lithuania and the Kaliningrad Region have been included in the study. The systematic names and classification follow Danilevsky (2019). The tribes, genera, and species are arranged alphabetically. The data concerning the geographical distribution were deduced from Danilevsky (2005, 2014, 2019), Peña et al. (2007), Sama, Rapuzzi (2011), Tatarinova et al. (2016), Özdikmen (2007), Rassi et al. (2015), Cherepanov (1979), Ehnström, Axelsson (2002), Lundberg, Gustafsson (1995), Dedyukhin et al. (2005), Duff (2016), Aleksandrowicz et al. (1996), Bartenev (2004, 2009), Sama (2002), Ilić, Curčić (2015), Serafim, Maican 
(2011), Picard (1929), Filimonov, Oudalov (2001), Belova et al. (2008), Danilevsky, Miroshnikov (1985), Dunskis, Barševskis (2018), Süda, Miländer (1998), Aleksandrowicz, Tsinkewich (2006) Twinn, Harding (1999), and others cited respectively in the text below. The biology-related data were deduced particularly from Palm (1959), Demelt (1966), Cherepanov (1979), Švácha (1989), Bily, Mehl (1989); Burakowski et al. (1990), Ehnström, Axelsson (2002), Sláma (1998), Brelih et al. (2006), Danilevsky (2014), and Vitali (2018).

The species trustworthily found in the region are listed herein without qualifying marks; species that were erroneously mentioned in published sources or still lack reliable information on their occurrence in the region are marked with a dash (-); the species that occur in the region and are not confirmed but expected (possible) in the territory are marked with a special symbol (产). Faunistic data contains the following information: district name (acronym), geographic name of the locality of collection or observation, the date of collection or observation (day, month, and year), collecting peculiarities (if present), the number of collected or observed specimens, and initials of collectors (col.) or observers (obs). Examined material is deposited in Kaunas Tadas Ivanauskas Zoological Museum (KZM), the Lithuanian Nature Research Centre of Vilnius University (NRC), Viešvile Strict Nature Reserve (administration) (VNR), the Institute of Forestry, the Lithuanian Research Centre for Agriculture and Forestry (IF), the private collection of Aleksandras Meržijevskis (AMC), the private collection of Rimantas Butvila (RBC), and the private collection of Vitalii I. Alekseev. The location of the deposited specimens is given only for rare species. The photographs of the specimens, including those posted on the websites https://www.inaturalist.org/ and https://macrogamta.lt//lt, were examined and observations were used herein as faunistic data and are marked with a special symbol (ब()). The threatened category (EU) of species included in the IUNC Red List of Saproxylic beetles (Cálix et al., 2018) is indicated by the same acronyms in the subchapter paragraphs.
The examined material was collected or observed by: Agnè Jastramskaitė (AJas), Agnè Kulpyte (AKul), Aidas Buivydas (AB), Aira Lažauninkienè (AL), Aistė Jarmalavičiūtè (AJa), Aistė Pranckūnaite (APr), Aistė Špokaite (AŠ), Aldona Stanionyte (ASt), Aleksandras Meržijevskis (AM), †Alfonsas Manikas (AMa), †Alfonsas Palionis (AP), Algimantas Jakimavičius (AJ), Algirdas Vilkas (AVi), Algis Saulius (AS), Algis Kvaraciejus (AKv), Almantas Kulbis (AK), Alvyra Patapavičienè (APa), Andrius Kubilius (AKu), Andrius Pašukonis (APaš), Andrius Petrašiūnas (APe), Armandas Kazlauskas (AKa), Armina Raugaitè (AR), Artūras Gedminas (AG), Artūras Vaisiauskas (AV), Arūnas Eismantas (AE), Arūnas Juknevičius (AJu), Arūnas Rimkus (ARi), Audronė Unikauskaitė (AU), Augustė Bundzaite (AB), Aurimas Mašalka (AMa), Aurelijus Narbutas (AN), Austeja Žumbakyte (AŽu), Aušra Žilinskienė (AŽ), Beatričè Kasieliauskaitė (BK), Benediktas Švažas (BŠ), $\dagger$ Borys Ogijewicz (BO), †Bronislaw Houwald (BH), Brigita Paulavičiūtè (BP), Dainius Matyžonok (DMa), Darius Baužys (DB), Dalius Dapkus (DD), Deividas Makavičius (DM), Deividas Sutkaitis (DS), Domilè Petravičiūtè (DP), Donatas Stanionis (DSt), Dovile Tylaitė (DT), Edita Medeina (EM), Edmundas Greimas (EGr), Egidijus Petrauskas (EP), Egle Vičiuvienė (EG), †Elena Gaidienè (EG), Elmaras Duderis (ED), Elvyra Mikšyte (EMi), Emanuelis Vansevičius (EV), Evaldas Čiplys (EČ), Gabrielè Mikalauskaitė (GMi), Gabrielè Stanaitytè (GSt), Gabrielè Vinickaitè (GVi), Gediminas Umbrasas (GU), Gediminas Petkus (GPe), Gerardas Paškevičius (GP), Giedrius Jieznas (GJ), Giedrius Markevičius (GM), Giedrius Švitra (GŠ), Gintare Umbrasaite (GUm), Gintautas Rugaitis (GR), Gintautas Steiblys (GS), Gustė Čingaitė (GČ), Gustė Vege (GV), Ieva Morkūnaite (IM), Ieva Nazgulija (IN), Indrè Vètaitė (IV), Irmantas Liepa (IL), Joana Lajauskienè (JL), Jolita Cicelienè (JC), Jogaila Treinavičius (JT), Jurga Motiejūnaite (JM), Jurgis Žižys (JŽ), Justas Janulis (JJ), Justina Iščišinaitė (JI), Jūratė Zabarauskienè (JZ), Karolina Vienažinskaitė (KVie), Kazimieras 
Martinaitis (KM), Kęstutis Jarmalavičius (KJ), Kęstutis Kišonas (KK), †Konstantinas Arris (KA), Kotryna Čaikauskaite (KČ), Kotryna Jaškauskaitè (KJa), Kotryna Šukyte (KŠ), Kristina Vaicekauskaite (KV), Kristina Valinčienè (KVa), Kristina Vitunskienė (KVi), Laima Prudnikovaite (LPr), Liana Bultje (LB), Lina Kaminskaitė (LK); Lina Paškevičiūtė (LP), Lina Rutkauskaitė (LR), Lina Straigytė (LSt), Linas Mikuta (LM), Linas Mockus (LMo), Lolita Salienè (LS), Loreta Mačiulienè (LMa), Mantas Adomaitis (MA), Mantas Jancevičius (MJ), Martynas Balsys (MB), Martynas Skučas (MS), Marytė Geciené (MG), Miglè Luko (ML), Miglè Šabūnaitè (MŠ), Mikhail Tsydenov (MT), Milda Umbrasiené (MU), Monika Brimaite (MBr), Motiejus Kalinauskas (MK), $†$ Natalja Kopylówna (NK), Nikolay Mavrov (NM), Nomeda Vèlavičienè (NV), Norbertas Noreika (NN), Oskaras Venckus (OV), Ovidijus Dumčius (OD), Paulius Audronis (PA); Paulius Ptakauskas (PP), Paulius Rupšas (PR), Paulius Zolubas (PZ), Pavel Alekseev (PA), Petroc ap Seisyllt (PS), Pijus Beliūnas (PB), Pijus Kreimeris (PK), Povilas Ivinskis (PI), Povilas Navickas (PN), †Povilas Rèklaitis (PRè), Ramunè Paliakaite (RPa), Rasa Bumblienè (RBu), Rasa Gaidienė (RGa), Rasa Gražulevičiūtè (RGr), Rasa Samajauskaitè (RSa), Rasa Vaišvilienè (RV), Rimantas Butvila (RB), Rimantas Kuprys (RK), Rimantas Pankevičius (RP), Rimvydas Gaidys (RG), Romas Ferenca (RF), Rugilè Romankevičiūtè (RR), Rūta Pareigytè (RPa), Rytis Skominas (RS), Samanta Sopyte (SSo), Saulius Drazdauskas (SD), Saulius Gaižutis (SG), Saulius Karalius (SK), Saulius Rumbutis (SR), Saulius Stašaitis (SS), Sigitas Juzėnas (SJ), Sigutis Obelevičius (SO), †Simonas Pileckis (SP), Šarūnè Pečiukonyte (ŠP), the students of Vytautas Magnus University (VMUst), the students of Vilnius University (VUst), †Tadas Ivanauskas (TI), Tadas Gružinskas (TG), Tadas Petrikas (TP), Taja Demčenko (TD), Tomas Legetavičius (TL), Tomas Pocius (TPo), Vaidas Balys (VBa), Valdimantas Grigonis (VaG), Vilius Grigaliūnas (VG), Viktoras Kaminskas (VKa), Vidas Brazauskas (VBr), Vidmantas Monsevičius (VM), Viktorija Burinskienè
(VBu), Viktorija Nomeikienè (VN), Vilma Pitkauskienè (VP), Vilija Eugenija Baciuškienè (VEB), Vincentas Tverkus (VTv), †Virgilijus Monsevičius (VMo), Virginija AkulienèKudirkaite (VA-K), Vitalii Alekseev (VA), Vitalijus Bačianskas (VB), Vita Kilienè (VK), Vytautas Gluoksnis (VGl), Vytautas Inokaitis (VI), †Vytautas Jonaitis (VJ), Vytautas Tamutis (VT), Vytautas Uselis (VU), Zita Gasiūnaite $(\mathrm{ZG})$, Žygimantas Obelevičius (ŽO), and Žilvinas Pūtys (ŽP).

Examined or reviewed materials were collected in the territories of 52 administrative districts of LT and 12 administrative districts of KR (Fig. 1).

The gridding of the maps of Lithuania is based on the borders of administrative districts according to the "Law of the Republic of Lithuania on the Administrative Units and Their Borders", No. I-558, 19 July 1994 (https://www.etar.lt/portal/lt/legalAct/TAR.0120FD7BCFFC/ ZhxPsGFEbL). Geographical names follow those listed in the document of the National Land Service under the Ministry of Agriculture of the Republic of Lithuania "Regulation on the Usage of Geographical Names in Maps", No. 1P-15, 3 February 2004 (https://e-seimas. lrs.lt/portal/legalAct/lt/TAD/TAIS.227707). The names of reserves follow those listed in the regulations of the State Service for Protected Areas under the Ministry of Environment of the Republic of Lithuania (http://www.vstt.lt/ VI/index. php\#r/57).

The following information, divided into seven paragraphs, is given for each species: (1) the scientific name; (2) examined actual data, including the acronyms of administrative districts, geographical names of reserves, details of record (if present), date of records, number of collected (observed) specimens, initials of collectors (observers); (3) actual faunistic data published in scientific papers and monographs (the taxonomic names another that accepted here, but mentioned in previous publications are given in brackets); (4) a brief review of the general distribution of the species; (5) a brief review of the biology of the species; (6) detailed local occurrence and phenology of the species; (7) comments, 


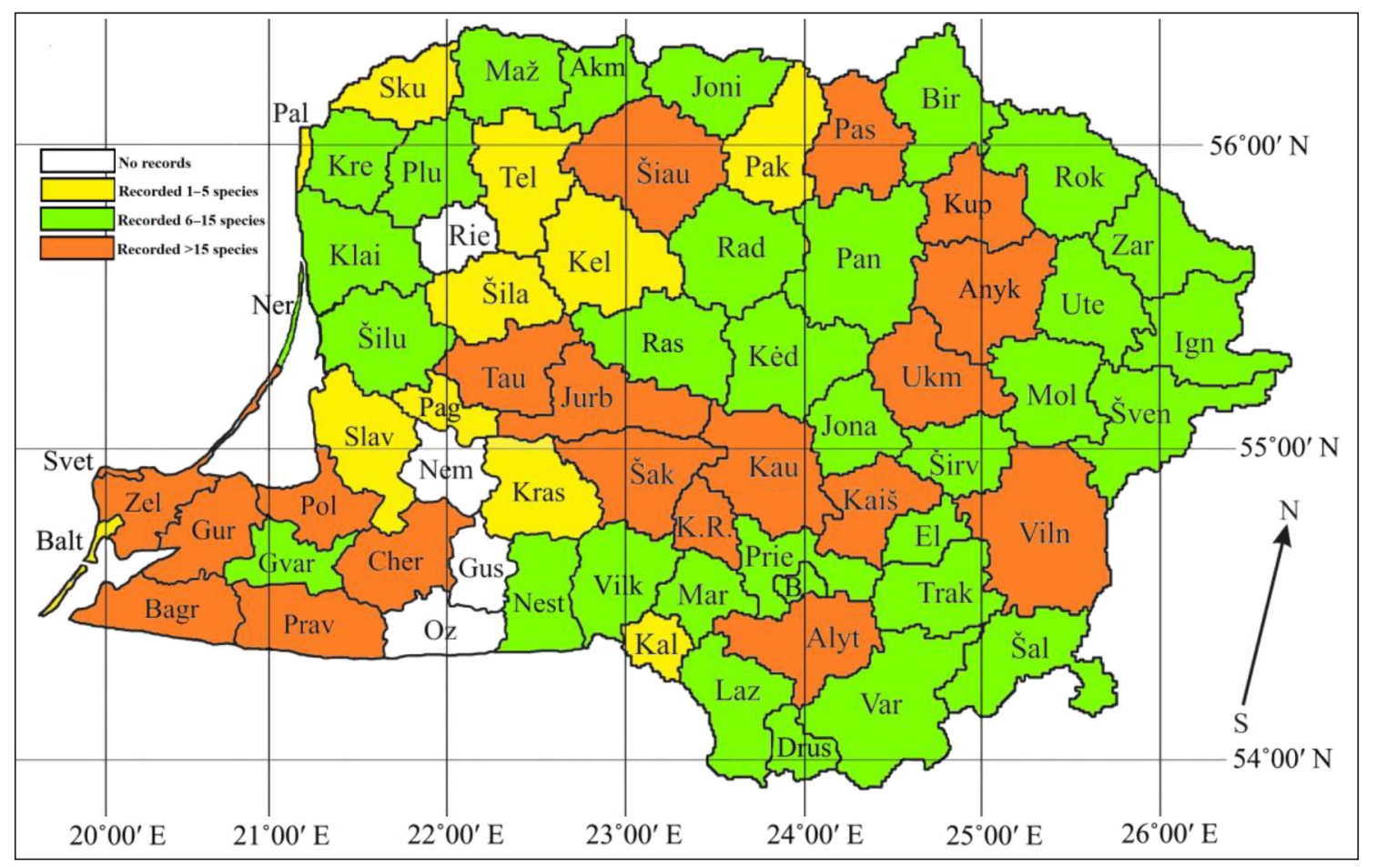

Fig. 1. Map of Lithuania (LT) and Kaliningrad region, Russia (KR) with grid of administrative districts; LT: Akm-Akmene;; Alyt-Alytus; Anyk-Anykščiai; B-Birštonas; Bir-Biržai, Drus-Druskininkai; El-Elektrènai; Ign-Ignalina (including Visaginas); Jona-Jonava; Joni-Joniškis; Jurb-Jurbarkas; KaišKašiadorys; Kal-Kalvarija; Kau-Kaunas; Kel-Kelmė; Kèd-Kèdainiai; Klai-Klaipėda; K.R.-Kazlų Rūda; Kre-Kretinga, Kup-Kupiškis; Laz-Lazdijai; Mar-Marijampolė; Maž-Mažeikiai; Mol-Molètai; Ner-Neringa; Pag-Pagègiai; Pak-Pakruojis; Pal-Palanga; Pan-Panevėžys; Pas-Pasvalys; Plu-Plungė; Prie-Prienai; Rad-Radviliškis; Ras-Raseiniai; Rie-Rietavas; Rok-Rokiškis; Sku-Skuodas; Šak-Šakiai; Šal-Šalčininkai; Šiau-Šiauliai; Šila-Šilale, Šilu-Šilute; Širv-Širvintos; Šven-Švenčionys; Tau-Taurage; Tel-Telšiai; Trak-Trakai; Ukm-Ukmergé; Ut-Utena; Var-Varena; Vilk-Vilkaviškis; Viln-Vilnius; ZarZarasai; KR: Bagr-Bagrationovsk; Balt-Baltiysk; Cher-Cherniakhovsk; Gur-Gur'evsk (including Kaliningrad); Gus-Gusev; Gvar-Gvardeysk; Kras-Krasnoznamensk; Nem-Neman (including Sovetsk); Nest-Nesterov; Oz-Ozersk; Pol-Polessk; Prav-Pravdinsk; Slav-Slavsk; Svet-Svetlogorsk; Zel-Zelenogradsk (including Svetly). The areas where the species were recorded are coloured

including details of the taxonomic interpretation of species distribution, listing in IUCN Red Lists and local occurrence.

The comparative estimation scale was used for species distribution (widely or locally distributed) and species abundance (abundant or rare) in the countries that individually follow the scheme suggested by Gutowski (1995). The values of threshold numbers of districts and records for the categorisation of the species were identified according to the following formulas:

$$
\begin{aligned}
& V_{d}=N \geq 5 / 2, \\
& V_{r}=V_{d} \times 2,
\end{aligned}
$$

where $V_{d}$ - value of threshold number of districts; $V_{r}$ - value of threshold number of records; $N \geq 5$ - the number of districts where five or more species of Lepturinae were detected.

In the case of our study, the detected values of the threshold numbers of districts was 22 for LT and 5 for KR, the values of the threshold number of records were 44 and 10, respectively (Fig. 2). All kinds of actual records (published, photographed, or found in collections) were used in this estimation. The records made from the same place (locality) within five consecutive days were regarded as one single record. 


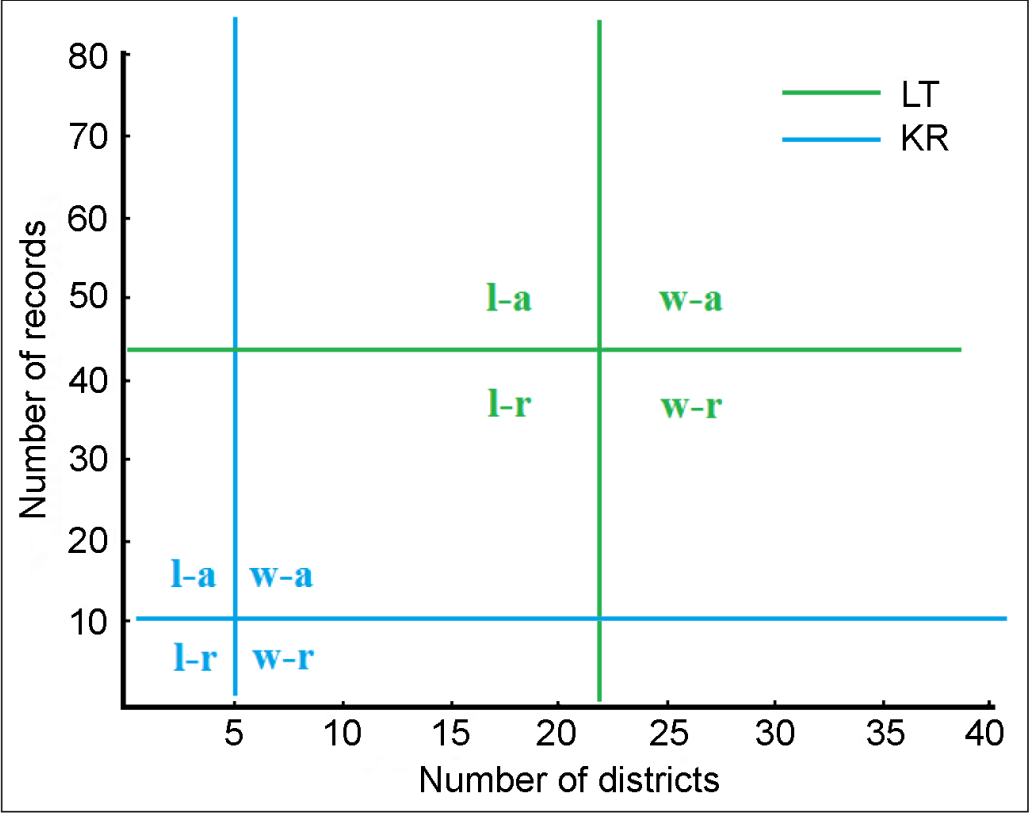

Fig. 2. Graphic interpretation of the distribution and abundance of Lepturinae (Cerambycidae) in the south-eastern Baltic region: $\mathrm{w}-\mathrm{a}$ - widely distributed, abundant; w-r - widely distributed, rare; $1-\mathrm{a}$ - locally distributed, abundant; 1-r - locally distributed, rare

\section{RESULTS}

Annotated checklist of Lepturinae (Cerambycidae) of the territory of south-eastern Baltic region

Family CERAMBYCIDAE Latreille, 1802

Subfamily Lepturinae Latreille, 1802

Tribe Lepturini Latreille, 1802

Genus Alosterna Mulsant, 1863

\section{产 A. ingrica (Baeckmann, 1902)}

Examined actual data. Absent. No material is available from LT and KR.

Published local records. LT: No actual faunistic information was published before; however, this species (Grammoptera erythropus ingrica) was ranked as very rare and noted as distributed in central and eastern parts of the country by Pileckis, Monsevičius (1997). KR: Alekseev, 2007 (erythropus ssp. ingrica), as improbable.

General distribution. This species is distributed in the eastern part of Europe (northward of Leningrad and Ivanovo regions) and Western Siberia, but it is rarely observed in most of its distribution range. The western border of its distribution range is not completely known; westernmost records are reported from Estonia (Süda, Miländer, 1998, as Grammopera eryth- ropus ssp. ingrica), eastern Latvia (Telnov et al., 2005, 2006, 2010), eastern Poland (Gutowski, 1995), eastern Slovakia (Sláma, 1998), and Belarus (Aleksadrowich et al., 1996, as Grammopera erythropus ssp. ingrica). The Chelyabinsk region is mentioned as the easternmost record of this species.

Notes on biology. Little is known of the life cycle of this species. Presumably, the larvae develop in deciduous wood. The adults were observed in June-July on a veteran oak in Latvia (Telnov et al., 2010), or visiting the blossom of Apiacea and Rossacea near oak forests in Russia (Egorov, 2002; Vlasov, 2019).

Local occurrence and phenology. Absent.

Comments. Based on the incorrect interpretation (Grammoptera erythropus ingrica) of this taxon and notes of its distribution proposed by Plavilstchikov (1936), this species was erroneously included in the lists of the local fauna of LT by Pileckis (1976) and Pileckis, Monsevičius (1997). Currently, Alosterna ingrica is accepted as a distinct species and regarded to be one of the rarest species of longhorn beetles in Europe (Danilevsky, 2014). Taking into account the distribution of the species in the neighbouring countries, the occurrence of this species in the region is plausible. IUCN Red List Category (EU) - VU. 
A. tabacicolor tabacicolor (DeGeer, 1775)

Examined actual data. LT: Akm: Kamanų valstybinis gamtinis rezervatas, 24.06.02.07.1980, 3, VM; Alyt: Punios šilas, 26.06. 2009, 1, RF; ibidem, 21.06.2017, 2, RF; Sabališkių miškas, 09.06.2020, on blossom of Apiacea, >10, VT; Vidzgirio botaninis draustinis, 05.06.1998, 1 , RF; Anyk: Traupis, 13.06.2020, 1 (ब), SO; ibidem, 23.06.2020, 1 (C), SO; Joni: Pavirčiuvès miškas, 20.06.2000, 1, RB; Jurb: Seredžius, 06.07.2017, 1, RF; Viešvilè, 24.05.2019, 1, VT; Viešvilès valstybinis gamtinis rezervatas, $12.06 .2008,1, \mathrm{VT}$; K.R.: Jürès miškas, 25.05.2000, 1, RF; Kazlų Rūda, 04.07.1996, 1, AM; Kaiš: Morkūnai, 15.06.2001, 1, VT; Būdos miškas, 18.06.2020, 2, RF; Strošiūnų miškas, 03.07.2009, 1, DSt; Kau: Braziūkai, 19.05.2019, 1, VT; Dubravos miškas, 07.08.1985, 1, RF; ibidem, 09-22.06.1993, 2, RF; Gaižènai, 10.06.2001, 1, VT; Jiesios kraštovaizdžio draustinis, 14.06.1982, 7, RF; ibidem, 16.06.1984, 5, RF; ibidem, 25.05.1986, 1, RF; ibidem, 28.05.1998, 3, RF; ibidem, 27.05.1999, 2, RF; ibidem, 12.06.2005, 1, RF; 29.08.2015, 2, RF; Kamšos miškas, 13.06.1995, 7, VT; ibidem, 11.06.2019, 2, VT; Karmèlava, 30.06.2003, 1, VI; ibidem, 19.06.2004, 1, VI; Kaunas (Ąžuolyno parkas), 24.05.2012, 1, VT; Kaunas (Freda), 03.06.1981, 1, RF; Kaunas (Kleboniškio miškas), 22.06.2003, 3, VI; Kaunas (Naugardiškès), 14.06.2017, 1 (Ф), VBr; ibidem, 20.05.2018, 1 (Ф), VBr; Kaunas (Pažaislio šilas), 20.07.1973, 3, EG; Kaunas (Romainiai), 29.06.2006, 1, RF; Kaunas (Žaliakalnis), 28.05.2003, 1, VI; ibidem, 20.06.2006, 2,VI; ibidem, 25.06.2010, 4, VI; ibidem, 07.06.2011, 3, VI; ibidem, 17.06.2012, 2, VI; ibidem, 22.06.2016, 1, VI; Meištinès miškas, 16.06.2019, VT; Pilènų miškas, 22.05.2011, 1, VI; Raudondvaris, 02.06.2001, 1, VI; ibidem, 24.05.2002, 1, VI; Klai: Giruliai, 10.06. 1990, 1, SK; Šernai, 17.06.1989, 2, SK; Kret: Kulūpènai, 13.06.1989, 3, SK; Kup: Mirabelio giria, 16.06.1991, 1, RP; Laz: Rinkoto miškas, 08.05.-09.06.2020, "window” trap, 1, VT; Maž: Renavas, 01.07.1991, 2, VM; Ner: Juodkrantè, 09.07.2003, 1, RF; ibidem, 07.07.2005, 1, RF; Pas: Trūliškis, 04.06.2006, 1, VB; Žadeikių miškas, 18.06.2004, 2, VB; Plu: Plokštinès miškas, 01-21.06.2020, "window" trap, 1, VT; Prie: Balbieriškio miškas, 09.06.2020, on blossom of Apiacea, >10, VT; miškas Gojus, 30.06.2015, 1, RF; Ras: Lyduvènai, 26.05.2018, 3, VT; Rok: Busiškis, 16.06.2019, 1 (Ф), PA; Šak: miškas Juškinè, 06.07.2008, 1, RF; ibidem, 20.06.2014, 1 (D), RF; ibidem, 04.07.2015, 1, RF; Tervydoniai, 13.06.2009, 1, RF; Šal: Zajašiškès, 09.06.2019, 1, VT; Šiau: Slydžiai, 02.06.2019, 18, VT; Paširvio miškas, 01-20.06.2020, "window" trap, 2, VT; Šilu: Ventè, 31.05.1988, 1, RF; Šven: Antašviešè, 23.06.2018, 1 (6), GM; Sariai, 12.06.2020, 1 (Ф), col. unknown; Tau: Viešvilès valstybinis gamtinis rezervatas, 13.06.2007, 1, RF; Ukm: Felinkos miškas, 06.06.2015, 1, RF; Vaisgèliškio botaninis draustinis, 28.06.1978, 1, GŠ́; Vytinèlès miškas, 30.05.2008, 1, TP; Vilk: Grybingirio gamtinis rezervatas, 16.06.2016, 2, RF; Vištytgirio botaninis-zoologinis draustinis, 30.05.2002, 2, RF; Viln: Maišiagala (Kalniškès), 02-23.06.2008, Malaise trap, 9, PI; ibidem, 01-23.06.2015, "window" trap, 3, PI; Pučkoriai, 08.06.2006, 1, RF; Verkių miškas, 12.06.1972, 1, VKa; ibidem, 17.07.1974, 1, VJ; ibidem, 25.05.2019, 1 (Ф), JM; Vilnius (Antakalnis), 01.06.2018, 2 (D), GM; Vilnius (Jeruzalè), 03.06.2018, 1 (Ф), GM; Vilnius (Kirtimai), 30.05.2000, 1, VT; KR: Bagr: Znamenka, 12.05.2002, 2, VA; Ladushkin, 08.06.2009, 1, VA; ibidem, 27.06.2010, 1, VA; $2 \mathrm{~km}$ S Medovoe, 29.05.2020, 1 (D), VA; Cher: 7 km NE Cherniakhovsk, 05.06.1995, 1, VA; ibidem, 19.06.2006, 1, VA; Cherniakhovsk, 09.06.2002, 1, VA; Pushkarevo, 26.06.2006, 1, VA; Gur: Kaliningrad, 07.05-26.05. 2019, 1, VA; Gvar: 5 km S Ozerki, 18.06.2019, 2 (D), VA; ibidem, 02.06.2020, 2 (d), VA; Nest: 2 km NE Krasnoles'e, 08.06.2008, 2, VA; Pol: 3 km SE Veselovka, 09.06.1998, 1, VA; Prav: Pravdinsk, 08.06.2019, 1, VA; Svet: Otradnoe, 29.06.2006, 1, VA; ibidem, 28.06.2011, 2 (Ф), VA; Maiskii, 13.06-02.07.2019, 1, VA; Zel: Riabinovka, 22.05.2002, 1, VA; ibidem, 20.06.2010, 1 (D), VA; 3 km NE Zelenogradsk, 12.06.2010, 3, VA; 2 km E Riabinovka, 20.06.2010, 1, VA; Russkoe, 04.07.2010, 2 (C), VA.

Published local records. LT: the actual faunistic information was provided for the occurrence of this species in Vilnius (Zawadzki, 1937; Staniulisówna, 1939) and Kaunas 
(Pileckis, 1963) districts. KR: Lentz, 1879; Bercio, Folwaczny, 1979; Alekseev, Sakhnov, 2002; Alekseev, 2006, 2007.

General distribution. This species is represented by eight subspecies (Danilevsky, 2019) and widely distributed throughout Palearctic Eurasia from Iberia to the Far East. However, the nominative subspecies occurs only in $\mathrm{Eu}-$ rope, north-western Turkey, and West Siberia. The eastern border of its distribution range reaches the Tomsk region; northwards, it goes to northern Scandinavia, Arkhangelsk, and Ukhta regions.

Notes on biology. The larvae of this species feed and tunnel in the bark or wood of dead, often decaying trunks of both coniferous and deciduous trees. Some authors stated that these beetles preferred stumps. The life cycle apparently lasts two years, with pupation in the spring or summer, in food substrate. Adults emerge in late spring or early summer; they are diurnal and widely anthophilous.

Local occurrence and phenology. This species is common in forested areas of the region but still not detected in some districts. Sometimes, on sunny days, they can be detected abundantly on blossom of various plants. Recorded from 37 districts (Fig. 3); the maximum of recorded adults was in June, the earliest record on 6 May, the latest on 29 August.

Comments. IUCN Red List Category (EU) - LC.

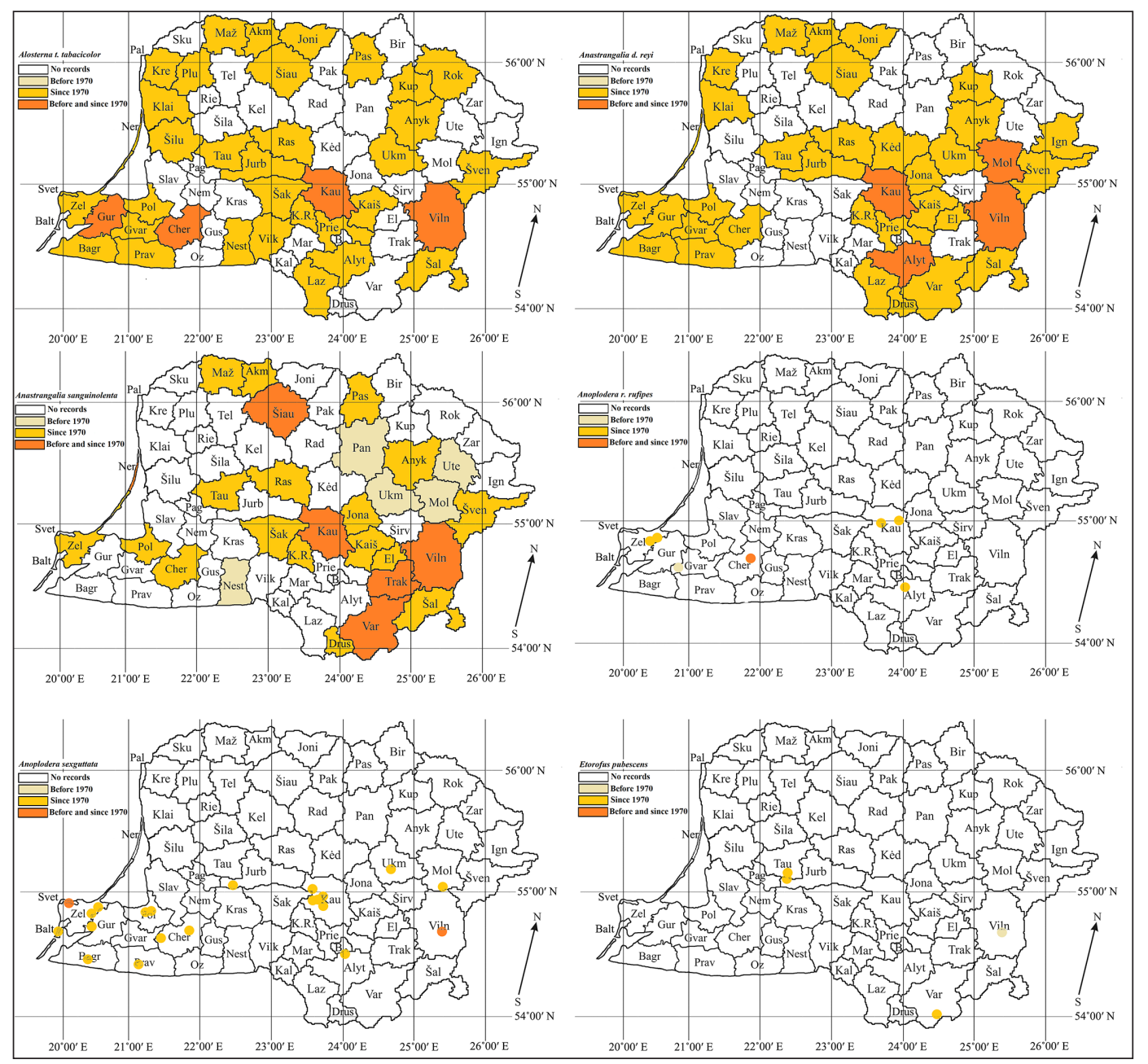

Fig. 3. Maps of distribution of Alosterna t. tabacicolor, Anastragalia d. reyi, Anastrangalia sanguinolenta, Anoplodera r. rufipes, Anoplodera sexguttata and Etorofus pubescens (Coleoptera: Cerambycidae: Lepturinae) in south-eastern Baltic region 
Genus Anastrangalia Casey, 1924

A. dubia reyi (Heyden, 1889)

Examined actual data. LT: Akm: Avižliai, 24.06.1993, 1, VM; Kamanų valstybinis gamtos rezervatas, 30.07.1980, 1, VM; ibidem, 2729.07.1991, 3, VM; ibidem, 30.06.1992, 1, VM; Karniškių telmologinis draustinis, 29.07.1991, 2, VM; Ramoniške, 23.06.1993, 2, VM; Užpelkiai, 1, 30.06.1999, 1, VM; Alyt: Punios šilas, 22.06.2017, 1, GS; Vidzgirio botaninis draustinis, 05.06.1998, 1, RF; Anyk: Katlèriai, 16.07.1985, 5, SK; ibidem, 07.07.1989, 1, SK; Želtiškiai, 29.06.2008, 1 (Ф), AE; Drus: Druskininkai, 12-15.06.1985, 3, EG; ibidem, 0722.06.1995, 3, VT; Gerdašiai, 15.06.2017, 4, VI; Viečiūnų miškas, 10.07.2017, 3, VI; ibidem, 03.06.2019, 1, VI; El: Paaliosé, 24.06.2020, 2 (C), JM; Ign: Ignalina, 22.07.1979, 1, VUst; Palabažio miškas, 20.06.2010, 1 (D), ŽP; Jona: Upninkèliai, 27.06.2015, 1, VI; Didysis Raistas, 13.06.2016, 1, VI; Joni: Ročkiai, 21.06.2019, 1, RB; Jurb: Sakalynès miškas, 15.06.2017, 3, RF; K.R.: Jūrè, 24.07.1974, 3, EG; ibidem, 19.07.1981, 1, RF; ibidem, 22.07.1982, 2, RF; 25.06.1983, 3, RF; Kaiš: Būdos miškas, 15.07.2007, 1, VI; Karčiupis, 23.07.1982, 1, RF; ibidem, 05.06.2003, 1, VI; Pravieniškès, 04.06.1990, 1, AM; Strošiūnų miškas, 04.07.2009, 1, DSt; Kau: Dubravos miškas, 17.06.1957, 1, SP; ibidem, 20-30.06.1958, 2, SP; ibidem, 20.06-11.07.1982, 3, RF; ibidem, 20.06-09.07.1984, 2, RF; ibidem, 29.06.01.07.1992, 3, RF; ibidem, 22.06.1993, 5, RF; ibidem, 28.06.1998, 3, RF; ibidem,27.06.1999, 1, PZ; ibidem, 21.07.2000, 1, RF; ibidem, 06.06.2007, 1, VI; Ežerèlis, 11.06.2002, 1, RF; Gervènupis, 06.06-10.07.1971, 6, EG; ibidem, 19.06.1974, 1, EG; ibidem, 25.06.1975, 1, EG; ibidem, 17.06.1975, 1, EG; Kačerginè, 17.07.2000, 1, VI; Karmèlavos miškas, 23.05.2002, 1, VI; ibidem, 06-28.06.2003, 2, VI; ibidem, 30.05.2004, 1, VI; ibidem, 06.06.2006, 1, VI; ibidem, 29.05.2007, 1, VI; ibidem, 17.07.2016, 1, VI; Kaunas (Kleboniškio miškas), - 07.1955, SP; ibidem, 02-03.06.2002, 2, VI; ibidem, 05.06.2016, 1, VI; Kaunas (Naugardiškès), 09.06.2019, 1 (Ф), VBr; Kaunas (Vičiūnai), 15.06.1985, 1, EG; Lomankos miškas, 16.06.2014, 1, VI; Netoniai, 08.06.2017, 2, VI; Pilènų miškas, 27.06.2010, 2, VI; ibidem,
23.06.2016, 1, VI; Raudondvaris, 26-27.06.1998, 4, EG; ibidem, 13-16.06.1070, 3, EG; ibidem, 13.06.1973, 1, RG; ibidem, 25.06.1975, 2, EG; ibidem, 14.06.2000, 1, VI; ibidem, 15.06.2001, 1, VI; Turžènų miškas, 05.07.2010, 1, VI; ibidem, 12.06.2012, 2, VI; Zapyškio miškas, 26.06.2019, 1, VT; Kèd: Babėnai, 10.07.1977, 1, VM; Klai: Giruliai, 01.07.1990, 1, SK; Šernai, 25.06.1989, 1, SK; Kret: Daubėnai, 20.07.1991, 1, SK; Kup: Drūlènai, 26-29.06.1991, 2, RP; Maž: Sedos giria, 10.07.2016, 1, GS; Mol: Molètai, 16.07.1969, 1, EG; Saldutiškis, 18.07.1975, 5, EG; Stirniai, 04.07.1965, 1, EG; Ner: Juodkrantè, 09.07.2004, 1, RF; Nagliu gamtinis rezervatas, 07.07.2003, 2, RF; Prie: Bačkininkų miškas, 23.06.1984, 11, RF; Ras: Lyduvènai, 26.05.2018, 1, VT; Šal: Stakų miškas, 09.06.2019, 2, VT; Šiau: Mirskiške, 07.07.1996, 1, VT; Paežerių miškas, 16.07.1998, 1, RF; Šven: Adutiškio miškas, 21.06.2001, 1, RF; Antaviešè, 23.06.2018, 1 (C), GM; Tau: Viešvilès valstybinis gamtinis rezervatas, 26.06.1991, 2, VM; ibidem, 11-12.06.1992, 2, VM; ibidem, 25.07.2000, 2, RF; Ukm: Dukstyna, 13.06.2000, 1, PI; Var: Čepkelių valstybinis gamtinis rezervatas, 17.06.1989, 1, RF; Puvočiai, 06.07.1978, 3, VUst; ibidem, 02.06.1984, 1, VUst; ibidem, 05.07.1984, 2, VUst; ibidem, 04.07.1988, 1, VUst; Ulos kraštovaizdžio draustinis, 23.06.1985, 4, RF; Varèna, 07-09.07.1995, 2, VT; Viln: Elniakampio miškas, 30.06.2018, 1 (Ф), GM; Grabijolai, 27.06.2003, 1, PI; Maišiagala (Kalniškès), 25.06.2006, 1, PI; ibidem, 09.06.1007, 1, PI; ibidem, 06.07.2008, 1, PI; ibidem, 24.06.2009, 1, PI; ibidem, 24.05.2010, 1, PI; ibidem, 02.06.2011, 1, PI; ibidem, 08-15.06.2015, "window" trap, 1, PI; Rastinènai, 30.06.2018, 1 (Ф), GM; Rūkainiu miškas, 23.06.2008, 1 (Ф), DB; Vilnius (Vingio Parkas), 19.06.2003, 1, SS; Vilnius, 25.05.1924, 2, BO; ibidem, 04.07.1999, 1, BP; KR: Bagr: 2 km W Kamenka, 15.06.2019, 2, VA; Cher: Pushkarevo, 26.06.2006, 1, VA; Gur: Kaliningrad, 09.06.2000, 1, VA; Gvar: Zehlau Bog, 21. 05.2007, 2, VA; ibidem, 18.06.2019, on flowers of Ledum palustre, 2, VA; Pol: $2 \mathrm{~km}$ N Sosnovka, 22.06.2010, 2, VA; Prav: 3 km SW Pravdinsk, 08.06.2019, 2, VA; Svet: Otradnoe, 29.06.2006, 3, VA; 2 km W Svetlogorsk, 28.06.2012, 1, VA; Zel: Riabinovka, 22.05.2002, 2, VA; ibidem, 
19.06.2002, 1, VA; ibidem, 08.07.2010, 2, VA; ibidem, 10.06.2014, 2, VA; 3 km NE Zelenogradsk, 13.06.2009, 1, VA; ibidem, 20.06.2012, 1, VA; ibidem, 13-30.06.2012, 1, VA; $3 \mathrm{~km} \mathrm{~N}$ Medvedevka, 04.07.2010, 1, VA; Izhevskoe, 03.07.2015, 1, VA; $1 \mathrm{~km}$ W Povarovka, 20.06.2019, 1, VA; Kostrovo, 20.06.2016, 2 (D), VA; Kremnevo, 18.06.2018, 1, VA; ibidem, 09.06.2020, 1 (Ф), VA; ibidem, 12.07.2020, 1 (C), VA.

Published local records. LT: Two taxons of the genus Anastrangalia (= Leptura $=A n$ oplodera), A. dubia (Scopoli, 1763) and A. reyi (Heyden, 1889) = inexpectata (Jansson, Sjöberg, 1928) have been noted for Lithuania as a distinct species since 1960 (Pileckis, 1960). However, the taxonomic position of those, including Siberian A. sequensi (Reitter, 1898), was recently determined based on the analysis of sequences of nucleotides in cytochrome C oxidase I (COI) and all were considered to be subspecies of A. dubia (Zamoroka et al., 2019). Consequently, the previous faunistic data on the taxons from LT should be merged and related to the subspecies A. dubia reyi, because the territory of the region is outside the distribution range of the nominative subspecies A. dubia dubia (Scopoli) or subspecies Anastrangalia dubia sequensi (Reitter) and is within the range of the subspecies of $A$. dubia reyi only (Zamoroka et al., 2019). The actual faunistic information related to this subspecies was given from Alytus, Kaunas (Ferenca, 2006), Lazdijai (Ostrauskas, Tamutis, 2012), Vilnius (Zawadzki, 1937 (Leptura sequensi s. inexpectata)); Staniulisówna, 1939 (Leptura sequensi); Ostrauskas, 2020 (Anastrangalia reyi), Elektrènai, Švenčionys, Varèna (Ostrauskas, 2020 (Anastrangalia reyi)) districts. KR: Lentz, 1879 (Leptura cincta); Bercio, Folwaczny, 1979 (Leptura inexpectata); Alekseev, 2007 (reyi).

General distribution. For this moment, the species is represented by five subspecies (Zamoroka et al., 2019; Danilevsky, 2019). The subspecies A. dubia reyi is widely distributed in northern and eastern Europe and is also known from the highlands of the Alps in isolated populations (Zamoroka et al., 2019) and northern Kazakhstan (Danilevsky, 2019).
The southern and westerns borders of its distribution range are not completely known and surely overlap with the range of the nominative subspecies in central Europe (Zamoroka et al., 2019) and with $A$. d. sequensi in West Siberia (Danilevsky, 2014). To the north, its distribution range goes as far as the border of the forest zone, up to $69^{\circ} \mathrm{N}$ in Finland and $65^{\circ} \mathrm{N}$ in the north-eastern part of European Russia.

Notes on biology. The larvae of this species develop in dead wood of Picea, Pinus, and, possibly, Abies. The life cycle lasts two years; pupation in wood, in spring, adults emerge in the last decade of May or June and could be active until August; they are diurnal and anthophilous, visit blossom mainly of Apiaceae, Asteraceae, Aruncus, and Ephilobium angustifolium.

Local occurrence and phenology. The species is widely distributed and quite frequent in the region. Recorded from 37 districts (Fig. 3); the maximum of recorded adults was in June, the earliest record on 23 May, the latest on 23 August.

Comments. The taxon A. dubia previously listed for LT in various checklists and catalogues should be related to $A$. dubia reyi. IUCN Red List Category (EU) - LC.

\section{A. sanguinolenta (Linnaeus, 1761)}

Examined actual data. LT: Akm: Kamanu valstybinis gamtinis rezervatas, 02.07.1980, 1, VM; Anyk: Katleriai, 08-09.07.1989, 3, SK; ibidem, 09.07.1991, 1, SK; ibidem, 15.07.1994, 1, SK; Drus: Randamonys, 14.06.1985, 1, EG; Viečiūnų miškas, 10.07.2017, 1, VI; El: Paaliosè, 24.06.2020, 1 (), JM; Jona: Būdų miškas, 15.06.2007, 1, VI; Didysis Raistas, 17.06.2010, 1, VI; ibidem, 13.06.2016, 1, VI; K.R.: Beržiniškès miškas, 07.07.2018, 4, VT; Jūrè, 22.07.1982, 1, RF; ibidem, 25.07.1983, 2, RF; Kaiš: Kruonis, -.-.1968-1973, 1, AM; Triliškès, 06.06.2007, 1, DSt; Kau: Braziūkai, 19 06 2019, 1, VT; Dubravos miškas, 25.06.1957, 3, SP; ibidem, 11.07.1982, 1, RF; ibidem, 09.07.1984, 1, RF; ibdem, 29.06.1992, 1, RF; Ežerèlis, 11.06.2002, 1, RF; ibidem, 21.06.2006, 1, AM; ibidem, 26.06.2008, 1, AM; Gervenupis, 20.06.1968, 1, EG; ibidem, 10.06.1972, 1, EG; 
ibidem, 07.06.1973, 1, RG; Karmèlavos miškas, 14.06.2001, 1, VI; ibidem, 30.06.2006, 1, VI; ibidem, 05.06.2008, 1, VI; Kaunas (Kleboniškis), 02.07.1956, 1, SP; Netoniai, 08.06.2017, 1, VI; Raudondvaris, 23.06.1974, 1, RG; ibidem, 114.06.1976, 1, EG; ibidem, 14.06.1985, 1, EG; Maž: Kiminiškè, 02.08.1991, 2, VM; Plinkšès, -.07.1972, 1, AMa; Mol: Stirniai, 10.06.1965, 1, EG; Ner: Juodkrantè, 25.07.1988, 1, RF; ibidem, 04.07.2004, 1, RF; ibidem, 08.07.2012, 1, VT; ibidem, 18.07.2012, 2, RF; ibidem, 25.07.2013, 1, RF; Nagliu gamtinis rezervatas, 10.07.2003, 2, RF; Pas: Miškas Lepšynė, 27.07.2004, 1, VB; Ras: Viduklès geležinkelio stotis, 10.07.1998, 1, VI; Šak: miškas Juškinè, 10.07.2003, 1, RF; ibidem, 08.07.2006, 1, RF; Šal: Stakų miškas, 09.06.2019, 1, VT; Šiau: Gedinčių miškas, 26.07.1957, 1, SP; Rekyvos miškas, 15.07.1998, 1, RF; Šven: Laukagalis, 16.06.2018, 1 (D), GM; Tau: Viešvilès valstybinis gamtinis rezervatas, 25.07.2000, 1, VU; Trak: Tolkiškès, 19.07.1993, 1, PI; Ukm: Pučionys, 24.06.1936, 1, PR; Ute: Saldutiškis, 05.07.1958, 1, EG; Var: Biniūnai (Baudzieriškis), 01.07.1939, AP; Užuožerès miškas, 29.05.2017, 1, RF; Ülos kraštovaizdžio draustinis, 23.06.1985, 1, RF; Viln: Maišiagala (Kalniškès), 08-15.06.2015, "window” trap, 1, PI; KR: Cher: 6 km NE Cherniakhovsk, 21.05.1993, 2, VA; 8 km NE Cherniakhovsk, 13.06.2016, 1, VA; Pol: $1 \mathrm{~km}$ N Sosnovka, 12.06.2019, 1, VA; Zel: $23 \mathrm{~km}$ of the Curonian Spit, 19.06.2007, 3, VA; ibidem, 25.06.2018, 1 (D), VA; Rybachiy, 17.07.2007, 1, VA; ibidem, 14.07.2010, 1, VA; ibidem, 12.07.2011, 3, VA; 2 km NE Kostrovo, 20.06.2016, 1, VA; ibidem, 30.06.2019, 1, VA.

Published local records. LT: This species is ranked as common and noted as distributed throughout the country by Pileckis, Monsevičius (1997) (Anoplodera). However, the actual faunistic information was given on the occurrence of this species only in Panevėžys, Varèna (Ferenca, 2006) Trakai, Vilnius (Staniulisówna, 1939) (Leptura), and Neringa (Bercio, Folwaczny, 1979) districts. This species was reported as common and numerous in the environs of Vilnius in the period of 1922-1934 by Zawadzki (1937) (Leptura). KR: Lentz, 1879 (Leptura); Bercio, Folwaczny, 1979 (Leptura); Alekseev, 2007.
General distribution. This species is widely distributed throughout Europe, from Great Britain to the Urals. The northern border of the distribution range reaches as far as $67^{\circ} \mathrm{N}$ in Scandinavia and $60^{\circ} \mathrm{N}$ in north-eastern European Russia; the southern border goes through the Iberian, Apennine, and Balkan peninsulas and the Caucasus; also, this species is known from Turkey, Kazakhstan, and West Siberia.

Notes on biology. The larvae develop two years in dead, wet, wood, stumps, and thick fallen branches of Picea, Pinus and Abies. Pupation in May-June; adults emerge in June-August, anthophilous, they usually visit blossom of Apiaceae, Aruncus, Knautia, Chrysanthemum, and Filipendula ulmaria.

Local occurrence and phenology. This species is widely distributed in the region, but is less abundant in the region than the above species. Recorded from 28 districts (Fig. 3); the maximum of recorded adults was in JuneJuly, the earliest record on 29 May, the latest on 2 August.

Comments. Ecological differences of the species with $A$. dubia reyi are unclear; the species seems to be more mosaically distributed in the region than the previous species. IUCN Red List Category (EU) - LC.

\section{Genus Anoplodera Mulsant, 1839}

A. (s. str.) rufipes rufipes (Schaller, 1783)

Examined actual data. LT: Kau: Pilènų miškas, 04.06.2011, 1, VI (KZM); KR: Cher: 10 NE Cherniakhovsk, 01.06.1994, 1, VA; Zel: Riabinovka, 20.06.2010, 2, VA; Divnoe Lake vicinity, 10.06.2014, 1, VA.

Published local records. LT: The actual faunistic information was given on the occurrence of this species in Alytus (Ferenca et al., 2006) and Kaunas districts (Ferenca, 2003; Inokaitis, 2009). KR: Lentz, 1879 (Leptura); Bercio, Folwaczny, 1979 (Leptura); Alekseev, Sakhnov, 2002; Alekseev, 2007; Alekseev, Bukejs, 2011.

General distribution. It is distributed from Iberia to the southern Urals and north-western Kazakhstan. It is absent or poorly known in the central part of European Russia; however, 
it is widely distributed in southern Europe, the Caucasus, noted for Anatolia and northern Iran. The nominative subspecies occurs only in Europe.

Notes on biology. The larvae of this species develop in dead wood of various Fagaceae, but they prefer Quercus. The life cycle lasts two years; pupation in wood, in spring; adults emerge in late spring or early summer, they are diurnal and anthophilous, visiting blossom mainly of bushes and trees, especially of Crataegus (Gorski, Tatur-Ditkowsky, 2015).

Local occurrence and phenology. The species is local and rare in the region. Recorded from five districts (Fig. 3); all records in June, the earliest record on 1 June, the latest on 20 June.

Comments. Possibly, it is an endangered species in the region and requires protection. IUCN Red List Category (EU) - LC.

\section{A. (s. str.) sexguttata (Fabricius, 1775)}

Examined actual data. LT: Alyt: Punios šilas, 21.06.2017, 2, RF; ibidem, 22.06.2017, 1 (Ф), KM; Kau: Bendrès miškas, 02.06.2016, 1, RF; Jiesios kraštovaizdžio draustinis, 11.06.2009, 1, AM; ibidem, 02.06.2016, 1, RF; Kaunas (Kleboniškio miškas), 03.06.2002, 1, VI; Kaunas (Romainiai), 20.06.2008, 1, RF; Vilkija, 10.06.1990, 1, RF; Mol: Šakimo miškas, 11.06.2019, 2, RF; Viln: Vilnius (Paneriai), 26.06.1981, 1, PI; KR: Bagr: 1 km W Kamenka, 15.06.2019, 1 (Ф), VA; Balt: Mechnikovo, 09.06.2019, 3 (D), VA; Cher: 10 km NE Cherniakhovsk, 16.06.1995, 1, VA; 7 km NE Cherniakhovsk, 19.06.2006, 3, VA; Pushkarevo, 26.06.2006, 1, VA; Gur: 3 km N Chkalovsk, 10.06.2014, 1, VA; ibidem, 19.06.2018, 1 (Ф), VA; Pol: 1 km N Sosnovka, 12.06.2019, 1, VA; Fevral'skoe, 28.06.2020, 1 (D), VA; Prav: 3 km S Pravdinsk, 08.06.2019, 1, VA; Svet: Otradnoe, 29.06.2006, 1, VA; ibidem, 30.06.2010, 2 (C), VA; ibidem, 28.06.2011, 2 (D), VA; Zel: 3 km W Riabinovka, 20.06.2010, 1, VA; 2 km NE Medvedevka, 04.07.2010, 1, VA.

Published local records. LT: The species was ranked as rare and noted as distributed in the eastern region by Pileckis, Monsevičius
(1997). The actual faunistic information was given on the occurrence of this species in Jurbarkas (Ivinskis et al., 2009), Kaunas (Inokaitis, 2004), Ukmergè (Stanionis, Petrikas, 2011), and Vilnius (Zawadzki, 1937; Staniulisówna, 1939) districts. KR: Lentz, 1879 (Leptura); Bercio, Folwaczny, 1979 (Leptura); Alekseev, Sakhnov 2002; Alekseev, 2007.

General distribution. It is distributed from Great Britain and Iberia to the southern Urals; northwards, reaching $60^{\circ} \mathrm{N}$ in Scandinavia, southern Finland, the regions of Leningrad and Moscow, and Udmurtia. This species is widely known in southern Europe, the Caucasus, Anatolia, and is noted for Algeria.

Notes on biology. The larvae of this species develop in dead wood of various Fagaceae, infected by fungus, especially by Hymenochaete rubiginosa, but they prefer Fagus and Quercus. The life cycle lasts two years, pupation in wood, in spring. Adults emerge in late spring or early summer, they are diurnal, anthophilous, and visit blossom mainly of Apiaceae, Crataegus, Filipendula, Valeriana, and Thalicrum.

Local occurrence and phenology. The species is locally distributed and rare in LT; however, it is more frequent in western parts of KR. Recorded from 14 districts (Fig. 3), the maximum of recorded adults was in June, the earliest record on 30 May, the latest on 6 August.

Comments. IUCN Red List Category (EU) - LC.

\section{Genus Etorofus Matsushita, 1933}

E. (s. str.) pubescens (Fabricius, 1787)

Examined actual data. LT: Jurb: Viešvilès valstybinis gamtinis rezervatas, 19.07.2001, 1, RF (KZM); ibidem, 22.06.1999, 1, VU; ibidem, 18-25.07.2000, 8, VU (VNR); ibidem 08.07.2002, 2, VU; ibidem, 18.07.2008, 2, VU (VNR); Tau: Viešvilès valstybinis gamtinis rezervatas, 17.07.2006, 1, RF (KZM); ibidem, 19.07.2007, 1, RF (VNR); ibidem, 15.07.2008, 1 (C), GS; ibidem, 30.07.2008, 1, RF (KZM); ibidem, 31.07.2009, 1 (D), RF; ibidem, 23.06.2011,2, RF (KZM); Var: Musteikos miškas, 04.07.2019, 2, RF (KZM); Užuožerès miškas, 01.07.2019, 1, RF (KZM); KR: no actual data. 
Published local records. LT: The actual faunistic information was given on the occurrence of this species only in Jurbarkas district (Ferenca, 2003) (Pedostrangalia). It was also noted for Vilnius district (Nowo-Wilejce) by Zawadzki (1937) (Sphenalia pubescens a. auriflua). KR: Lentz, 1879 (Strangalia); Bercio, Folwaczny, 1979 (Strangalia); Alekseev, 2007 (Etorufus), as improbable.

General distribution. It is distributed mainly in Europe, from Iberia to the Urals (Chelyabinsk region); northwards, its distribution range reaches Sweden (Västern - Götland), southern Finland, and the Udmurt Republic (Russia). The southern border of its distribution range goes through the Iberian, Apennine, and Balcan peninsulas; also, this species is known from Turkey, but still not observed in Moldova, southern Ukraine, the Caucasus, and the southern part of European Russia.

Notes on biology. The life cycle of this species is not completely known. The larvae were reported from moist, moderately decaying wood of Pinus. Development lasts for about three years; pupation in wood, in early summer. Adults emerge in the last decade of June and can be active until August; they are diurnal and anthophilous, visiting blossom mainly of Apiaceae, Aruncus sp., and Ephilobium angustifolium.

Local occurrence and phenology. This species is local and rare in Lithuania; however, a relatively stable population was detected in Viešvilè Strict Nature Reserve where the adults visiting blossom of Eupatorium cannabinum and various Apiaceae have been continuously observed since 1999. Recorded from four districts (Fig. 3), the maximum of recorded adults was in July, the earliest record on 22 June, the latest on 30 July.

Comments. Not found in research in KR and no locality known in the territory from the literature. Alekseev (2007) doubted the possible occurrence in KR and mentioned the species as a faunal component of the adjacent lands only. However, that may be a too hasty conclusion. The search in $\mathrm{KR}$ is reasonable and it may be possible to find the species there. The species (as Pedostrangalia) is included in the European
Red List of saproxylic beetles (IUCN Red List Category (EU) - VU).

\section{Genus Grammoptera Audinet-Serville,} 1835

G. (s. str.) abdominalis (Stephens, 1831)

Examined actual data. LT: Kau: Kaunas (Kleboniškio miškas), 12.05.2019, 1, KM (KZM); KR: Cher: $1 \mathrm{~km}$ E Cherniakhovsk, 25.05.1994, 1, VA; Zel: 2 km W Riabinovka, 20.06.2010, 1, VA.

Published local records. LT: Recenly recorded in the environs of Kaunas (Tamutis, Martinaitis, 2019). KR: Bercio, Folwaczny, 1979 (variegata Germ.); Alekseev, 2007.

General distribution. It is distributed from Ireland and Iberia to Krasnodar region; northwards, as far as southern Sweden, Belarus. This species is widely distributed in southern Europe, Asia Minor, the Caucasus, and northern Iran.

Notes on biology. According to Demelt (1966), the larvae of this species develop in dead thin branches of a diameter of $2-5 \mathrm{~cm}$, infected by white rot fungus. Švácha (1989) specified that dead branches of deciduous trees infested by Vuilleminia comedens are most conductive to the development of larvae of this species. Quercus, Aesculus, Corylus, and rarely other deciduous trees are noted as host plants (Švácha, 1989; Ehnström, Axelsson, 2002; Danilevsky, 2014; Vitali, 2018). The life cycle lasts two years (Švácha, 1989; Sláma, 1998) or one year (Burakowski et al., 1990). Adults emerge in late spring or early summer; they are diurnal and anthophilous, and especially prefer Crataegus, Sorbus, and Cornus.

Local occurrence and phenology. The species is insufficiently known and probably rare in the region; it was found in three districs. The adults were recorded at the end of May and June.

Comments. G. abdominalis is regarded as rare and insufficiently known species in Europe, especially in its northern part (Bily, Mehl, 1989; Burakowski et al., 1990). The Lithuanian record is the northernmost currently known record of this species in the eastern Baltic region. IUCN Red List Category (EU) - LC. 


\section{G. (s. str.) ruficornis ruficornis (Fabricius, 1781)}

Examined actual data. LT: Kaiš: Karčiupis, 20.05.1990, 1, RF; Kau: Akademija, 13.06.1995, 4, VT; ibidem, 15.06.1996, 1, VT; ibidem, 13.06.2008, 1, VT; Gervènupis, 04.06.1996, 1, AM; Jiesios kraštovaizdžio draustinis, 28.0514.06.1982, 8, RF; ibidem, 25.05.1984, 2, RF; ibidem, 25.05.1986, 3, RF; ibidem, 20.05.1990, 1, RF; ibidem, 27.05-16.06. 1999, 4, RF; ibidem, 0206.06.2000, 3, RF; ibidem, 23.06.2004, 4, RF; ibidem, 02.06.2016, 2, RF; Karmelava, 23.06.2005, 1, VI; Kaunas (Ąžuolyno parkas), 24.05.2012, 1, VT; Kaunas (Kleboniškis), 12.05.2002, 3, VI; Kaunas (Marvelè), 15.05.2019, >20 on blossom of Malus domestica, VT; Kaunas (Romainiai), 19.06.2008, 2, RF; Kaunas (Žaliakalnis), 2528.05.2003, 2, VI; Netoniai, 06.06.2014, 1, RF; Ringaudai (Obelynè), 22.05.2001, 1, VT; Samylai, 18.06.2008, 1, VI; Klai: Giruliai, 24.05.1990, 1, SK; Šernai, 17.06.1989, 2, SK; Kup: Paketuriai, 27.05.1992, on blossom of Sorbus aucuparia, 2, RP; Maž: Renavas, 15.06.2010, 1, DM; Ner: Juodkrantè, 26.05.2008, 1, RF; Ras: Lyduvėnai, 26.05.2018, 1, VT; Šak: miškas Juškinè, 01.06.2003, 1, RF; Šiau: Slydžiai, 31.05.1995, 1, VT; Šven: Melagènų miškas, 07.06.2020, 1 (D), obs. unknown; Tau: Eičiai, 10.06.2008; 1, RF; Karšuvos giria, 13.06.2006, 1, VT; Ukm: Dukstynos miškas, 29.04.2014, 1, GŠ; Viln: Pučkoriai, 06.06.2006, 2, RF; Vilnius (Žemieji Paneriai), 21.06.1974, 1, AJ; Vilnius (Fabijoniškès), 10.06.2019, 1 (), AJu; KR: Bagr: Bogdanovka, 24.05.2009, 3, AV; $3 \mathrm{~km}$ S Novomoskovskoe, 12.05.2014, 1, VA; Mamonovo, 25.05.2019, 4, VA; Cher: $1 \mathrm{~km}$ E Cherniakhovsk, 09.05.2008, 1, VA; Gur: Kaliningrad, 27.05.1996, 1, VA; ibidem, 16.05.2009, 1, VA; 1 km W Kaliningrad, 14.06.2020, 2 (D), VA; Chkalovsk, 18.06.2007, 2, VA; ibidem, 20.06.2010, 3, VA; ibidem, 21.06.2019, 1 (6), VA; Nest: 2 km NE Krasnoles'e, 08.06.2008, 1, VA; Pol: Sosnovka, 22.06.2010, 2, VA; Prav: 2 km S Pravdinsk, 08.06.2019, 1, VA; Svet: Otradnoe, 02.07.2008, 2, VA; ibidem, 29.06.2011, 1 (), VA; Zel: 1 km W Riabinovka, 20.06.2010, 1 (ब), VA; 2 km NE Kostrovo, 09.06.2020, 1 (D), VA; Kremnevo, 20.05.2020, 1 (क), VA.
Published local records. LT: The species was ranked as rare and noted as distributed in eastern and south-western regions of LT by Pileckis, Monsevičius (1997). The actual faunistic information was given on the occurrence of this species in Vilnius (Zawadzki, 1937), Kaunas (Pileckis, Monsevičius, 1997), and Neringa (Šablevičius, 2004, 2007) districts. KR: Lentz, 1879; Bercio, Folwaczny, 1979; Alekseev, Sakhnov, 2002; Alekseev, 2007.

General distribution. The nominative subspecies is distributed in Europe, from Portugal and Ireland to the southern part of European Russia; northwards, its distribution range reaches southern Scandinavia, Estonia, northern Belarus and Ukraine, and the Belgorod region (Russia). It is widely distributed in southern Europe and Anatolia.

Notes on biology. The larvae of this species develop in dead, fungus-infected branches of various deciduous trees, but they were also observed in Picea abies. The life cycle lasts one year; pupation in the spring, adults emerge in April or May; they are diurnal and anthophilous.

Local occurrence and phenology. This species is common in deciduous forests, orchards, and parks of the region. Recorded from 22 districts (Fig. 4); the maximum of observed adults was in June, the earliest observation on 29 April, the latest on 26 June.

Comments. IUCN Red List Category (EU) - LC.

\section{产 G. (s. str.) ustulata ustulata (Schaller, 1783)}

Examined actual data. Absent. No material is available either from LT or KR.

Published local records. LT: Tamutis et al., 2011, as expected. KR: Alekseev, 2007, as improbable.

General distribution. The nominative subspecies is distributed in Europe from Portugal and Great Britain to Anatolia, Moldova, western Ukraine, Belarus, and Latvia. It is widely distributed in southern Europe; northwards, its distribution range reaches southern Sweden.

Notes on biology. The larvae of this species develop in dead branches, fungus-infected and 


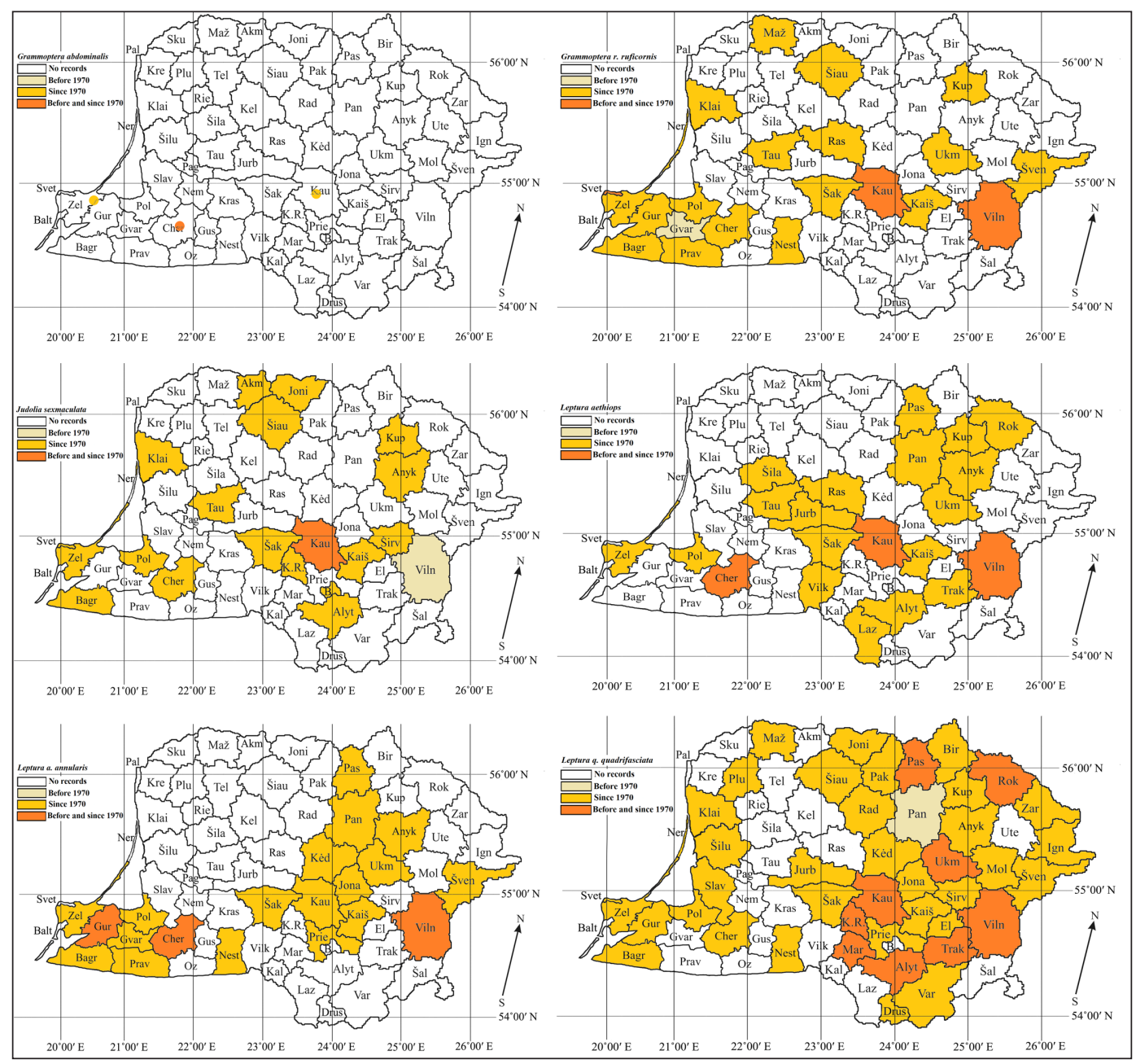

Fig. 4. Maps of distribution of Grammoptera abdominalis, Grammoptera r. ruficornis, Judolia sexmaculata, Leptura aethiops, Leptura a. annularis, and L. q. quadrifasciata (Coleoptera: Cerambycidae: Lepturinae) in south-eastern Baltic region

overgrown with lichens, of various deciduous trees, mostly Quercus, Tilia, Acer, Juglans, Alnus, and Crataegus. The life cycle lasts one year, pupation in spring inside wood. Adults emerge in May or June; they are diurnal and anthophilous.

Local occurrence and phenology. Absent.

Comments. The species is recorded from all neighbouring countries, so its occurrence is plausible in the region. IUCN Red List Category (EU) - LC.

\section{Genus Judolia Mulsant, 1863}

\section{J. sexmaculata (Linnaeus, 1758)}

Examined actual data. LT: Akm: Kamanu valstybinis gamtinis rezervatas, 02.07.1980, 1, VM; Alyt: Punios šilas, 22.06.2017, 1, GS;
Anyk: Šimonių miškas, 11.06.1997, 1, RP; B: Šilènai, 20.06.2009, 1, GS; Joni: Žagarès miškas, 29.06.2001, 1, RB; K.R.: Jūrè, 22.05.1990, 1, RF; Kaiš: Būdos botaninis draustinis, 01-14.07.2020, "window" trap, 6, VT; Pravieniškès, 05.06.1996, 1, AM; Kau: Dubravos miškas, 20.06.1965, 1, SP; ibidem, 15.06.1980, 1, RF; ibdem, 28.06.1981, 1, RF; ibidem, 20-27.06.1982, 2, RF; ibidem, 0814.06.1998, 1, RF; ibidem, 16.05.1999, 1, PZ; Karmèlavos miškas, 08-28.06.2003, 2, VI; ibidem, 31.05.2004, 1, VI; ibidem, 09-18.06.2006, 2, VI; Lomankos miškas, 31.05.2014, 1, VI; ibidem, 09.06.2014, 1, VI; Neveronys, 29.05.2003, 1, VI; Raudondvaris, 15.06.2001, VI; Klai: Giruliai, 01.07.1990, 1, SK; Melnragè, 20.07.1984, 1, SK; Pèžaičiai, 31.05.1989, 1, SK; Kup: Mirabelio 
miškas, 23.06.1991, 1, RP; Šak: miškas Juškinė, 06.07.2008, 1, RF; Šiau: Paširvio miškas, 10.07.2020, „window“ trap, 1, VT; Širv: Bartuškio miškas, 20.06.2020, 1 (D), AJu; Tau: Artoji pelkè, 09.06.2000, 1, VU; Viešvilès valstybinis gamtinis rezervatas, 27.05.2003, 1, VU; KR: Bagr: 2 km W Kamenka, 15.06.2019, 1, VA; Cher: 9 km NE Cherniakhovsk, 11.06.1994, 1, VA; Pushkarevo, 26.06.2006, 1, VA; Pol.: 1 km SE Fevral'skoe, 28.06.2020, 1, VA; Svet: Maiskii, 13.06.2019, 1, VA; Zel: 2 km W Riabinovka, 20.06.2010, 2, VA.

Published local records. LT: The species was ranked as rare and noted as distributed in central and eastern regions of LT by Pileckis, Monsevičius (1997). The actual faunistic information was published on the occurrence of this species only in Kaunas (Pileckis, 1963; Inokaitis, 2004, 2009). Also, this species is noted for Vilnius region without actual data by Zawadzki (1937). KR: Lentz, 1879 (Pachyta); Bercio, Folwaczny, 1979; Alekseev, Sakhnov 2002; Alekseev, 2007.

General distribution. It is widely distributed throughout Europe, from northern Great Britain, the montanous regions of France, and Andora to the Urals, northern Kazakhstan. Northwards, its distribution range goes as far as the border of the forest zone, up to $70^{\circ} \mathrm{N}$ in Finland and $66^{\circ} \mathrm{N}$ in the north-eastern part of European Russia (Usinsk). The southern border goes through Andora, southern France, northern Italy, Switzerland, Austria, Hungary, northern Romania (Serafim, Maican, 2011), Ukraine (Kiev, Kharkov, Donetsk), and the Orienburg region.

Notes on biology. Knowledge of the life cycle of this species is poor. Previous notes on its biology reported by Cherepanov (1979) and Švácha (1989) were based on the studies of Siberian "Judolia sexmaculata", which currently is treated as J. dentatofasciata (Mannerheim, 1852). Presumably, it is very similar; no noticeable difference between the biology of these species was indicated by Danilevsky (2014). The life cycle of both species lasts two years. The larvae feed in decaying sapwood of roots or stumps below ground level; pupate in wood, at the beginning of summer. Adults emerge during the last decade of June, are antrophilous and can be active until August. Various coniferous trees are regarded as possible hosts for J. sexmaculata, and Picea is mentioned as the most favourite. The records of deciduous trees, such as Tilia and Populus, as host plants of the species (Švácha, 1989; Danilevsky, 2014) originate from Siberia and belong to J. dentatofasciata.

Local occurrence and phenology. This species is locally distributed and rare in the region. Recorded from 20 districts (Fig. 4); the maximum of recorded adults was in June, the earliest record on 16 May, the latest on 20 July.

Comments. IUCN Red List Category (EU) - NT.

\section{Genus Leptura Linnaeus, 1758}

L. (s. str.) aethiops Poda, 1761

Examined actual data. LT: Alyt: Punios šilas, 26.06.2008, 1, VT; Anyk: Traupis, 13.06. 2020, 1 (ד), SO; Jurb: Viešvilès valstybinis gamtinis rezervatas, 20.06.2000, 2, VU; ibidem, 18.07.2000, 2, VU; Kaiš: Būdos miškas, 12.06.2013, 1, VB; Kruonis, 28.06.1976, 1, AM; Kau: Dubravos miškas, 14.06.1956, 2, SP; ibidem, 13-17.06.1957, 2, SP; ibidem, 27.06.1958, 3, SP; ibidem, 19.06.1982, 2, RF; ibidem, 30.06.1984, 1, RF; ibidem, 06.07.1985, 1, RF; ibidem, 12.06.2009, 1 (Ф), GSt; Gaižènai, 24.05.1936, 1, PR; Gervènupis, 06.06.1971, 1, EG; ibidem, 09.06.1972, 1, EG; Karmèlavos miškas, 12.06.2007, 2, VI; ibidem, 06.06.2011, 1, VI; Kaunas (Kleboniškio miškas), 10.06.2000, 1, VI; ibidem, 05.06.2016, 1, VI; Lomankos miškas, 05.06.2014, 1, VI; Raudondvaris, 27.05.2000, 4, VI; ibidem, 14.06.2000, 1, VI; ibidem, 28.05.2001, 1, VI; ibidem, 06.06.2001, 1, VI; ibidem, 09.07.2001, 1, VI; Turžènų miškas, 12.06.2012, 1, VI; Kup: Mirabelio miškas, 18.06.1991, 1, RP; Laz: miškas Trakas, 19.06.2020, 1 (Ф), LR; Pan: Naujarodžių miškas, 03.06.2017, 1 (Ф), GM; Pas: Rinkūnų miškas, 12.06.2005, VB; Ras: Plauginių miškas, 19.06.2020, 1 (C), RV; Rok: Juodupè, 06.06.1938, 1, AP; miškas Paduobys, 13.06.2020, 1 (D), GM; Šak: Sintautai, 05.07.1991, 4, SK; Tervydoniai, 14.06.2015, 1, RF; ibidem, 13.06.2020, 1 (D), RF; 
Šila: Požerè, 12.07.1976, 1, AMa; Tau: Viešvilès valstybinis gamtinis rezervatas, 18.07.2000, 1, VU; Trak: Jogèlonių miškas, 26.07.2020, pheromone trap for Ips typographus, 1, DMa; Tamašava, 28.06.1997, 1, PI; Tolkiškès, 05.07.1978, 1, VUst; Ukm: Mašinių miškas, 12.06.2020. 1 (D), KJ; Vilk: miškas Vištytgiris, 31.05.2002, 1, RF; miškas Drausgiris, 12.06.2013, 1, RF; Viln: Maišiagala (Kalniškès), 27.06.2009, 1, PI; Paberžè environs (Medyna), 18.06.1933, 1, BH; Pavilnių regioninis parkas, 12.06.2017, 1 (D), AK; Vilnius (Baltupiai), 03.06.2019, 1 (()), JM; Vilnius (Paneriai), 29.05.1973, 1, PI; Verkių miškas, 12.06.1972, 1, VKa; ibidem, 23.05.1975, 1. PI; ibidem, 26.06.1976, 1, VUst; KR: Cher: $7 \mathrm{~km}$ NE Cherniakhovsk, 19.06.2006, 1, VA; 4 km NE Cherniakhovsk, 10.06.2020, 1 (Ф), VA; Zel: Divnoe Lake, 10.06.2014, 3, VA; 4 km W Riabinovka, 07.06.2016, 1, VA; Pol: Sosnovka, 12.06.2019, 1, VA.

Published local records. LT: This species is ranked as common and noted as distributed throughout the country except the coast of the Baltic Sea and south-western regions by $\mathrm{Pi}$ leckis, Monsevičius (1997). However, the actual faunistic information was given on the occurrence of this species only in Kaunas (Ferenca, 2006), Vilnius (Staniulisówna, 1939) (Strangalia), and Trakai (Ostrauskas, 2020) districts. The species was reported as common and numerous in the environs of Vilnius in the period of 1922-1934 by Zawadzki (1937) (Stenura). KR: Lentz, 1879 (Strangalia atra Fabr.); Bercio, Folwaczny, 1979 (Strangalia); Alekseev, 2007; Alekseev et al., 2015.

General distribution. It is distributed from Spain and France to the Far East, Sakhalin, and Kuril Islands. The northern border of its distribution range goes through the southern coast of the Baltic Sea, Latvia, Estonia, Moscow region, and the southern part of the Komi Republic. The species is widely distributed in central and southern Europe; however, its occurrence in Greece, Anatolia, and the Caucasus was doubted by Danilevsky (2014).

Notes on biology. The species is largely polyphagous on various deciduous trees, Quercus, Alnus, Betula, Carpinus, Corylus, Salix, Tilia,
Acer, and Populus, and was occasionally found on coniferous trees. According to Cherepanov (1979), the larvae develop in relatively thin (3-6 cm in diameter) dead stems, usually in the inferior part; however, Sláma (1998) observed the larvae in dead rotten stems with a diameter of $15-30 \mathrm{~cm}$. Pupation occurs inside wood in spring. The life cycle lasts two years. Adults emerge in May or June; they are diurnal and anthophilous, visiting blossom mostly of Apiaceae, Rosaceae, and Asteraceae.

Local occurrence and phenology. This species is locally distributed in the region and occurs quite rarely in KR. Recorded from 21 districts (Fig. 4); the maximum of recorded adults was in June, the earliest record on 23 of May, the latest on 18 July.

Comments. IUCN Red List Category (EU) - LC.

\section{L. (s. str.) annularis annularis Fabricius,} 1792

Examined actual data. LT: Anyk: Šimonių miškas, 20.06.1997, 1, RP; Jona: Upininkèliai, 27.06.2015, 1, VI; Kaiš: Būdos botaninis draustinis, 01-14.07.2020, "window" trap, 2, VT; Būdos miškas, 15.06.2007, 1, VI, ibidem, 25.06.2008, 1, RF; ibidem, 12.06.2013, 1, RF; Grabuciškès, 08.06.2019, in copula, 2 (D), JM; Karčiupis, 23.07.1982, 1, RF; Pravieniškès, 04.06.1989, AM; Kau: Karmèlavos miškas, 13.07.2001, VI; ibidem, 15.06.2005, 1, VI; ibidem, 28.05.2007, 1, VI; ibidem, 12.06.2007, 1, VI; ibidem, 08.06.2012, 1, VI; Kaunas (Kleboniškio miškas), 11.06.2002, 2, VI; Kaunas (Romainiai), 20.06.2006, 2, VI; Lomankos miškas, 17.07.2015, 1, VI; Raudondvaris, 09.07.2001, 1, VI; Kèd: Pašilių miškas, 14.07.2020, 1 (Ф), KV; Žeimelių miškas, 10.06.1994, 1, GŠ; Pas: miškas Didieji Grūžiai, 06.06.2007, 1, VB; Prie: miškas Gojus, 30.06.2015, 2, RF; Šak: Tervydoniai, 22.06.2013, 1, RF; ibidem, 14-28.06.2015, 2, RF; ibidem, 13.06.2020, in copula, 1 (क), RF; Ukm: Verškainių miškas, 14.07.1996, 1, GŠ Viln: Bradeliškès, 16.06.2018, 1 (D), ŽP; Maišiagala, 20.06.1978, 1, GŠ; KR: Bagr: 3 km W Kamenka, 15.06.2019, 2 (D), VA; Cher: Pushkarevo, 26.06.2006, 3, VA; Gur: $2 \mathrm{~km} \mathrm{~N}$ 
Chkalovsk, 08.07.2020, 1 (Ф), VA; Gvar: 4 km S Ozerki, 18.06.2019, 1 (Ф), VA; Nest: $2 \mathrm{~km}$ NE Krasnoles'e, 08.06.2008, 1, VA; Pol: 3 km SE Veselovka, 09.06.1998, 1, VA; 2 km N Sosnovka, 22.06.2010, 1, VA; ibidem, 12.06.2019, 3 (D), VA; 1 km SE Fevral'skoe, 28.06.2020, 5 (d), VA; Prav: 3 km SW Pravdinsk, 08.06.2019, 1, VA; Zel: Riabinovka, 19.06.2002, 1, VA; ibidem, 20.06.2010, 1, VA; ibidem, 07.06.2016, 1, VA.

Published local records. LT: The species was ranked as rare and noted as distributed in central and eastern regions by Pileckis, Monsevičius (1997). The actual faunistic information was given on the occurrence of this species in Vilnius (Staniulisowna, 1939) (arcuata), Švenčionys (Ferenca et al., 2002) (mimica), Panevėžys (Ivinskis et al., 2009), and Ukmergè (Stanionis, Petrikas, 2011) (mimica) districts. It is also listed in the checklist of beetle species recorded in Kaukinè botanical-zoological reserve [Kaukinès botaninis-zoologinis draustinis] without actual data (Šablevičius, 2000). KR: Lentz, 1879 (Strangalia); Bercio, Folwaczny, 1979 (Strangalia arcuata); Alekseev, Sakhnov 2002 (arcuata); Alekseev, 2006, 2007.

General distribution. It is distributed from France to the Far East, Sakhalin, and Kuril Islands; the northern border of its distribution range goes through the southern coast of Baltic Sea, Latvia, Estonia, Leningrad, Vologda regions, and the Udmurt Republic. The species is sporadically distributed in central Europe (Burakowski et al., 1990; Sláma, 1998; Schmidl, Bussler, 2003; Bartenev, 2004; Monnerat et al., 2016) and excluded from the list of the Italian fauna (Sama, Rapuzzi, 2011).

Notes on biology. The species is largely polyphagous on various deciduous trees $A l$ nus, Betula, Salix, Tilia, Acer, Populus, Quercus, Carpinus, and Corylus; it can occasionaly be found on Picea and Abies. The larvae develop in moist decaying wood over the period of two to three years. Adults emerge in May or June; they are diurnal and anthophilous, mostly on Apiacea, Rosacea, and Asteracea.

Local occurrence and phenology. This species is widely distributed but not abundant in the region. Recorded from 20 districts (Fig. 4); the maximum of recorded adults was in June, the earliest record on 28 May, the latest on 26 July.

Comments. The taxa under the name Leptura mimica Bates, 1884, previously regarded as a synonym, is currently considered to be a subspecies of L. annularis (Danilevsky, 2014, 2019) or even a valid species, and occurs in Japan and Sakhalin (Saito et al., 2002; Rossa et al., 2017). IUCN Red List Category (EU) - NT.

\section{L. (s. str.) quadrifasciata quadrifasciata Linnaeus, 1758}

Examined actual data. LT: Alyt: Daugu Sala, 08.08.2020, 1 (Ф), RS; Anyk: Svèdasai, 15.07.2019, 1 (D), EČ; Bir: Miegonys, -.07.1971, 1, AMa; Drus: Druskininkai, 20.07.2015, 1, col. unknown; ibidem, 30.07.2020, 1 (D), col. unknown; Viečiūnų miškas, 10.07.2017, 1, VI; ibidem, 28.06.2018, 1, VI; Ign: Ignalina, 31.07.1971, 1, col. unknown; ibidem, 17.07.1979, 1, VUst; Pivorai, 01.07.2017, 1 (Ф), AK; Visaginas, 10.08.2008, col. unknown; Jona: Būdų miškas, 23.06.2019, 1 (ब), KVa; Joni: Bariūnai, 03.07.2002, 1, RB; ibidem, 28.07.2004, 1, RB; Girdžiūnai, 15-28.07.2003, 2, RB; Satkūnai, 08-19.07.1998, 2, RB; Šarkiai, 19.07.2019, 3, RB; K.R.: Beržiniškès miškas, 2018.07.07, 1, VT; Jūrè, 03.07.1983, 1, RF; ibidem, 17.06.1984, 1, RF; ibidem, 03.08.1984, 2, RF; ibidem, 16.07.1992, 1, RF; Kazlų Rūda, 02.07.1968, 1, EG; Paskarlupis, 23.07.2017, 1 (Ф), EM; Kaiš: Kruonis, 15.07.1976, 1, AM; Strošiūnų miškas, 27.07.2010, 1, DSt; ibidem, 09.07.2018, 1 (D), obs. unknown; Triliškès, 24.07.2009, 1, DSt; Kau: Akademija, 24.07.2012, 1 (D), VBr; Berūkštinès miškas, 02.07.1963, 1, col. unknown; Braziūkai, 10.08.2004, 1, VT; ibidem, 08.07.2018, 1, VT; Dubravos miškas, 12.07.1981, 1, RF; ibidem, 09.08.1984, 3, RF; ibidem, 03.08.1984, 1, RF; Girionys, 22.06.2019, 1 (Ф), col. unknown; Jiesios kraštovaizdžio draustinis, 11.07.1981, 1, RF; ibidem, 16.05.2000, 1, RF; Karmèlava, 05.08.2008, 1, VI; Lomankos miškas, 17.07.2015, 1, VI; Noreikiškès, 14.07.1996, 1, VT; Papiškinès miškas, 12.07.2019, 2, VT; Raudondvaris, 28.07.2007, 1, VI; Kèd: Pašilių miškas, 16.07.2020, 1 (Ф), KV; Klai: Giruliai, 01.07.1990, 1, SK; Klošiai, 
07.08.2009, 1 (Ф), RGr; Melnragè, 08.07.1984, 1, SK; Kup: Mirabelio miškas, 23.06.1991, RP; Maž: Kūlupis, 25.07.2009, 1 (Ф), NV; Plinkšès, -.07.1972, AMa; Mar: Želsva, 20.07.2019, 1 (D), AŽ; Mol: Bražiškès, 12.06.2019, 1 (D), AB; Luokesa, 11.07.2012, 1 (D), AKa; Sližiškès, 15.06.2018, 1 (D), GM; Ner: Juodkrante, 16.07.2000, 1, RF; ibidem, 07.07.2018, 1, RF; ibidem, 26.07.2020, 1 (D), col. unknown; Pak: Vèbarai, 23.07.2014, 1, SD; Pan: Povilauskai, 21.07.1939, AP; Pas: Moliūnų miškas, 02.08.2005, 1, VB; Pasvalys, 14.07.2005, 1, VB; Šimoniai, 14.07.2004, 1, VB; Žadeikių miškas, 22.09.2005, 1, VB; Plu: Prūsaliai, 17.08.2015, 1 (), ŽP; Prie: Bačkininkai, 07.08.2020, 1 (Ф), LS; Papilvis, 28.06.2020, 1 (Ф), JI; ibidem, 08.07.2020, 1 (()), JI; Rok: Busiškis, 15.07.2018, 1 (D), PA; Bradesių šilelis, 19.07.2020, 1 (Ф), LB; Gilių miškas, 11.08.2020, 1 (D), SJ; Šak: miškas Juškinè, 18.06.2000, 1, RF; ibidem, 28.07.2005, 1, RF; ibidem, 11.07.2013, 1 ('), RF; ibidem, 17.06.2018, 1, RF; miškas Rūdšilis, 26.07.2020, 1 (ब), RS; Raninè, 05.08.2020, 1, RF; Sudargo miškas, 26.07.2020, 1 (C), LSt; Tervydoniai, 07.08.2015, 1, RF; Šiau: Agailių miškas, 23.07.1999, 1, RF; Einoraičiai, 15.07.1998, 1, RF; Paširvio miškas, 12.03.2020, in rotten wood of birch, 2 larvae, VT; ibidem, 10.07.2020, „window“ trap, 1, VT; Šilu: Šilutè, 08.07.1979, 1, VUst; ibidem, 19.06.2014, 1 (D), OV; Žalgirių miškas, 18.06.2002, 1, RF; Širv: Vaidziuliškiai, 19.08.2020, 1 (D), GMi; Šven: Antaviešè, 23.06.2018, 1 (Ф), GM; Laukagalis, 16.06.2018, 1, VI; Melagènų miškas, 21.08.2010, 1 (ㅁ), MU; Možerio miškas, 01.08.2020, 1 (D), MK; Spenglo miškas, 26.07.2020, 1 (Ф), col. unknown; Ukm: Taujènai (miškas Girelè), 26.07.2020, ŽO; Var: Čepkelių valstybinis gamtinis rezervatas, 03.08.1977, 1, VM; ibidem, 17.07.1985, 1, RF; Pogarenda, 20.07.1977, 1, VM; Puvočiai, 18.07.1974, 1, VUst; ibidem, 14.07.1979, 2, VUst; ibidem, 14.07.1983, 1, VUst; ibidem, 20.06.1984, 1, VUst; Ülos kraštovaizdžio draustinis, 23.06.1985, 1, RF; Viln: Arvydų miškas, 19.07.2020, 1 (Ф), JM; Daubènai, 30.07.2020, 1 (Ф), APr; Maišiagala (Kalniškès), 13.07.2007, 1, PI; ibidem, 26.08.2007, 1, PI; ibidem, 18.07.2008, 1, PI; ibidem, 03-10.08.2008, 1, PI; ibidem, 28.08.2009, 1, PI; ibidem, 28.07.2010, 5, PI; ibidem, 13.08.2013, 1, PI; ibidem, 0916.08.2015, 1, PI; Paberžė environs (Medyna), 15.07.1933, 1, BH; Sidaronys, 23.06.2019, 1, GM; Veliučionys, -.07.1971, 1, AMa; Verkiu miškas, 01.07.2008, 1, PI; Vilnius (Avietynè), 18.07.2020, 1 (Ф), LP; Vilnius (Šiaurès miestelis), 19.07.2019, 1 (D), JM; Vilnius (Žalieji Ežerai), 21.07.2019, 1 (Ф), JM; Zar: Dusetos, 16-29.07.1979, 3, VUst; Varniškès, 16.07.2019, 1 (Ф), LR; Zaduoja, 04.07.2009, 1 (), VG; KR: Bagr: 3 km S Novomoskovskoe, 07.07.2009, 1, VA; Ul'anovka, 19.07.2010, 1 (Ф), VA; Ladushkin, 09.08.2010, 1 (), VA; 2 km W Kamenka, 15.06.2019, 1 (Ф), VA; Cher: 1 km NE Cherniakhovsk, 15.07.1993, 1, VA; ibidem, 26.06.1995, 1, VA; 5 km NE Cherniakhovsk, 19.06.2006, 1, VA; Gur: 2 km N Chkalovsk, 08.07.2020, 1 (Ф), VA; Nest: 2 km NE Krasnoles'e, 08.06.2008, 1, VA; Pol: 1 km S Fevral'skoe, 28.06.2020, 1 (D), VA; Slav: Diunnoe, 09.07.1998, 1, NM; Svet: Otradnoe, 11.07.2018, 1 (Ф), VA; Svetlogorsk, 07.08.2019, 1 (6), VA; Zel: 3 km W Riabinovka, 20.06.2010, 1 (Ф), VA; ibidem, 08.07.2010, 1 (Ф), VA; Rybachii, 14.07.2010, 1 (Ф), VA; ibidem, 04.07.2011, 1 (Ф), VA; Donskoe, 30.06.2011, 1 (D), VA; Svinoe Bog, 06.08.2020, 1 (ब), VA; 2 km NE Kostrovo, 18.06.2018, 2 (Ф), VA; ibidem, 30.06.2019, 1 ('), VA; ibidem, 18.08.2020, 1 (()), VA.

Published local records. LT: This species is ranked as very common and noted as distributed throughout the country, except the coastal region of the Baltic Sea, by Pileckis, Monsevičius (1997). The actual faunistic information was given on occurrence of this species in Alytus, Marijampolè, Panevėžys, Pasvalys, Rokiškis, Trakai, Ukmergè (Ferenca, 2006), Radviliškis Vilnius (Ostrauskas, Tamutis, 2012), Elektrènai, Ignalina, Švenčionys and Trakai (Ostrauskas, 2020) districts. This species was reported as common and numerous in the environs of Vilnius and Trakai in the period of 1922-1938 by Zawadzki (1937), Mazurowa, Mazur (1939) and Staniulisówna (1939) (Strangalia). KR: Lentz, 1879 (Strangalia); Bercio, Folwaczny, 1979 (Strangalia); Alekseev, Sakhnov, 2002; Alekseev, 2006, 2007. 
General distribution. It is widely distributed throughout the Palaearctic region (excluding Africa), from Great Britain and Iberia to the Far East, Korea, Sakhalin, and Hokkaido. The northern border of its distribution range reaches $68^{\circ} \mathrm{N}$ in Scandinavia and $64^{\circ} \mathrm{N}$ in European Russia. The species is widely distributed in central and southern Europe, Anatolia, Iran, and the Caucasus.

Notes on biology. The species is largely polyphagous on various deciduous: Betula, Salix, Populus, Alnus, Fagus, Quercus, Corylus, Tilia, Aesculus, and can occasionaly be found on $\mathrm{Pi}$ cea and Abies. The larvae develop in moist decaying wood over a period of three years. Adults emerge in May and June; they are diurnal and anthophilous, feeding mostly on blossom of Asteraceae, Apiaceae, and Rosaceae.

Local occurrence and phenology. This species is widely distributed and common in the region. Recorded from 49 districts in the region (Fig. 4); the maximum of recorded adults was in July, the earliest record on 16 May, the latest on 22 September.

Comments. IUCN Red List Category (EU) - LC.

\section{L. (Macroleptura) thoracica thoracica Creutzer, 1799}

Examined actual data. LT: Ukm: Užulènis, 30.06.1934, 1, AP (KZM); KR: no actual data.

Published local records. LT: This species is ranked as rare and noted as distributed in the eastern region of LT, by Pileckis, Monsevičius (1997). The actual faunistic information is given on the occurrence of this species (Strangalia thorasica) in the environs of Druskininkai by Zawadzki (1937) and in Ukmergè district (Ferenca, 2006). KR: Alekseev, 2007 (Macroleptura).

General distribution. It is distributed from Slovenia, the eastern parts of Slovakia and Poland, the Baltic countries, and Finland to the Far East, Sakhalin, and Kunashir; northwards, it is known in southern Finland, Karelia, and Komi (Russia). The southern border of its distribution range is not clear in Europe; the species is extremely rare in Slovenia (Bre- lih et al., 2006), and Serbia (Ilić, Curčić, 2015); it is noted for Bosnia and Herzegovina and Romania; however, it has still not been found in Hungary, Austria, the Czech Republic, Bulgaria (Danilevsky, 2019), southern Ukraine (Bartenev, 2004), and the Caucasus (Danilevsky, 2014).

Notes on biology. The species is largely polyphagous on deciduous trees, but in central Europe it prefers Fagus. The larvae develop in the wood of dead trees where they pupate in June. Most often, the females lay eggs in the upper parts (from $5 \mathrm{~m}$ upwards) of the stems. The life cycle lasts three or four years. Adults emerge in summer; they are diurnal and anthophilous, feeding mostly on the blossom of Apiaceae.

Local occurrence and phenology. There are missing recent data on the occurrence of this species in the region. A single specimen in LT, collected by Alfonsas Palionis in Ukmerge district, is stored at KZM and was examined during the study. The actual record reported by Zawadzki (1937) from Druskininkai lacks voucher material. It was not found during our research time frame in $\mathrm{KR}$ and there is no locality known in the territory from literature. Alekseev (2007) supposed a possible occurrence in $\mathrm{KR}$ at the western periphery of its distribution area only. It is an extremely rare or possibly extinct species in the region.

Comments. IUCN Red List Category (EU) - EN.

\section{Genus Lepturalia Reitter, 1913}

\section{L. nigripes nigripes DeGeer, 1775}

Examined actual data. LT: Viln: Paberžè environs (Medyna), -.-.1888, 1, BH (KZM); KR: no actual data.

Published local records. LT: This species is ranked as very rare and noted as distributed in the eastern region of LT by Pileckis, Monsevičius (1997). The actual faunistic information is given on the occurrence of this species (Strangalia nigripes) only in the Vilnius district by Zawadzki (1937); it was noted for LT (Litwa) by Kinel (1917) without actual data. KR: Alekseev, 2007, as improbable. 
General distribution. It is distributed from Scandinavia, the eastern part of Poland, the mountainous areas of Slovakia, Austria, and Slovenia to the Far East. It is common in the northern part of European Russia and Siberia and is rare or absent in central and southern Europe (Burakowski et al., 1990; Sláma, 1998; Bartenev, 2009; Barševskis, Savenkovs, 2013).

Notes on biology. The species is polyphagous on deciduous trees but prefers Betula and Populus. The larvae develop in moist decaying wood ("white rot") over a period of three years; young adults appear in May and June; they are diurnal and anthophilous, mostly on Apiaceae and Rosaceae.

Local occurrence and phenology. It is extremely rare or even extinct species in the region; known from a single district.

Comments. IUCN Red List Category (EU) - EN.

\section{Genus Lepturobosca Reitter, 1912}

L. virens (Linnaeus, 1758)

Examined actual data. LT: Ign: somewhere in Ignalina district, -.07.1964, 1, SP (KZM); Kau: somewhere in Kaunas district, 20.07.1972, 2, col. unknown (KZM); KR: no actual data.

Published local records. LT: This species is ranked as rare and noted as distributed in the eastern region of LT by Pileckis, Monsevičius (1997). The actual faunistic information was given on the occurrence of this species only in Vilnius district (Zawadzki, 1937) (Leptura). KR: Lentz, 1879 (Leptura); Bercio, Folwaczny, 1979 (Leptura); Alekseev, 2007, as improbable.

General distribution. It is distributed from Iberia, the French Alps, and Scandinavia to the Far East and Sakhalin. This species is widely distributed in northern Europe, while in central and southern regions it inhabits mainly mountainous areas.

Notes on biology. The larvae of this species develop in dead wood of various coniferous trees, but prefer Pinus; additionally noted Betula as a host plant by Ehnström, Axelsson (2002). The life cycle lasts two years; pupation in wood, in late spring or early summer. Adults emerge in June-July and could be active until
September; they are diurnal and anthophilous, visit the blossom mainly of Apiaceae, Asteraceae, Sambucus, Ephilobium angustifolium.

Local occurrence and phenology. It is an extremely rare or even extinct species in the region; just few actual records are known that are more than 45 years old (Fig. 5). Not found during the research time frame in KR and no locality is known in the territory from literature.

Comments. The species is quite frequent in eastern and north-eastern parts of Latvia (Gailis, Vilks, 2001; Barševskis, Lecka, 2019). IUCN Red List Category (EU) - LC.

\section{Genus Nivelia Mulsant, 1863}

产 $N$. sanguinosa (Gyllenhal, 1827)

Examined actual data. Absent. No material is available from LT and KR.

Published local records. LT: Tamutis et al., 2011, as expected; KR: Alekseev, 2007, as expected.

General distribution. It is distributed from the mountainous regions of central Europe and Scandinavia to the Far East, Japan (Hokkaido). It is common in the north-eastern part of European Russia; however, it is still not known in its southern regions or in central and eastern Ukraine.

Notes on biology. The larvae of this species develop in dead wood of various deciduous trees, mostly on Betula, Populus, Acer, Padus, Salix, Corylus, Alnus, and Crataegus. The life cycle lasts one-to-two years, pupation in the spring inside wood. Adults emerge in JuneJuly; they are diurnal and anthophilous.

Local occurrence and phenology. Absent.

Comments. The species is recorded from all the neighbouring countries, so its occurrence is plausible in the region. IUCN Red List Category (EU) - EN.

Genus Pachytodes Pic, 1891

P. cerambyciformis (Schrank, 1781)

Examined actual data. LT: Anyk: Šeiminykščiai, 15.07.2000, 1, AJa; $B$ : Birštonas, 01.07.1996, 1, RF; Kau: Jiesios kraštovaizdžio draustinis, 21.06.1981, 1, RF; ibidem, 20.06.1983, 2, RF; ibidem, 16.06.1984, 1, RF; ibidem, 
22.07.1984, 1, RF; ibidem, 26.06.1997, 2, RF; ibidem, 06.07.1999, 1, RF; ibidem, 09.06.2000, 1, RF; ibidem, 25.06.2005, 1, AM; ibidem, 27.06.2008, 1, AM; ibidem, 11.06.2009, 1, AM; Kamšos miškas, 25.06.2007, 5, VI; Kaunas (Freda), 25.06.1978, 1, RF; Lomankos miškas, 19.06.2010, 1, VI; Noreikiškès, 05.06.1985, 1, SG; ibidem 17.07.2001, 2, VI; Raudondvaris, 14-21.06.2000, 5, VI; Ringaudai (Obelynè), 29.06.1987, 1 SP; Klai: Melnragè, 10.07.1984, 1, SK; Šernai, 17-25.06.1989, 2, SK; Šak: miškas Juškinè, 06.07.2008, 1, RF; Tervydoniai, 20.06.2020, 1 (D), RF; Pag: Pagègiu miškas, 26.06.2020, 1 (C), GM; Plu: Plokštinès miškas, 12.08.2020, 1, VT; Vilk: Pavištyčio miškas, 02.07.2020, 1 (D), KM; Viln: Nemenčinè, 23.06.1973, 1 SP; KR: Bagr: $2 \mathrm{~km}$ S Novomoskovskoe, 08.06.2009, 1, VA; ibidem, 02.07.2014, 1 (D), VA; ibidem, 01.06.2019, 1 (D), VA; Ladushkin, 27.06.2010, 2, VA; 4 km W Kamenka, 15.06.2019, 2 (D), VA; Cher: 7 km NE Cherniakhovsk, 09.06.2002, 1, VA; ibidem, 19.06.2006, 2, VA; Pushkarevo, 26.06.2006, 1, VA; Gur: 2 km N Chkalovsk, 19.06.2018, 2 (D), VA; 1 km W Kaliningrad, 14.06.2020, 3 (Ф), VA; Nest: 2 km NE Krasnoles'e, 08.06.2008, 2, VA; Pol: 2 km N Sosnovka, 22.06.2010, 1, VA; ibidem, 12.06.2019, 1, VA; 2 km SE Fevral'skoe, 28.06.2020, 2 (D), VA; Prav: 3 km S Pravdinsk, 08.06.2019, 1, VA; Svet: $1 \mathrm{~km} \mathrm{~W}$ Svetlogorsk, 02.06.2003, 1, VA; Otradnoe, 02.07.2008, 1, VA; Zel: Riabinovka, 20.06.2010, 3, VA; ibidem, 02.06.2019, 1 (D), VA; $3 \mathrm{~km} \mathrm{~N}$ Medvedevka, 04.07.2010, 1, VA; Vzmor'e, 07.07.2011, 1 (Ф), VA; 2 km NE Kostrovo, 18.06.2018, 1 ('), VA; $2 \mathrm{~km}$ W Povarovka, 20.06.2019, 2, VA.

Published local records. LT: This species is ranked as very rare and noted as distributed in central, eastern, and south-western regions of LT, by Pileckis, Monsevičius (1997). The actual faunistic information was published on the occurrence of this species in Klaipeda (Ivinskis et al., 2009), Kaunas (Ferenca, 2004) (Judolia); Inokaitis, 2004, 2009; Mulerčikas et al., 2011), and Vilnius (Milander et al., 1984 (Judolia); Ivinskis et al., 2009) districts. KR: Lentz, 1879 (Pachyta octomaculata); Bercio, Folwaczny, 1979 (Judolia); Alekseev, Sakhnov, 2002 (Judolia); Alekseev, 2007.
General distribution. It is distributed from Iberia and Great Britain to Samara region (Russia); however, it is rarely observed or absent in northern and eastern parts of Europe. The northern border of its distribution range goes through the southern coast of the Baltic Sea, Latvia, Estonia, and Moscow region (Russia). The species is widely distributed in central and southern Europe (Sláma, Slámova, 1996; Sláma, 1998; Georgiev et al., 2018), while its occurrence in Anatolia and the Caucasus was doubted by Danilevsky (2014).

Notes on biology. The species is largely polyphagous, but prefers deciduous trees Quercus, Castanea, Carpinus, Betula, Alnus, and Populus; also, it was observed on Picea and Pinus. The larvae develop underground, in dead roots, pupation in the ground near host. The life cycle lasts two years. Adults emerge in late spring or early summer; they are diurnal and anthophilous, feeding on the blossom of Apiaceae, Rosaceae, and Aruncus.

Local occurrence and phenology. This species is widely distributed and quite common in $\mathrm{KR}$, while it is local and rare in LT. Recorded from 17 districts (Fig. 5); the maximum of recorded adults was in June, the earliest record on 28 May, the latest on 12 August.

Comments. IUCN Red List Category (EU) - LC.

\section{产 P. erraticus (Dalman, 1817)}

Examined actual data. Absent. No material is available from LT and KR.

Published local records. LT: No records. KR: Lentz, 1879 (Pachyta septemsignata Küst.); Bercio, Folwaczny, 1979 (Judolia erratica a.7signata Küst.).

General distribution. It is widely distributed in the Palaearctic Eurasia from Spain to Krasnoyarsk region, and north-western China. The northern border of its distribution range is not completely known; earlier sightings for some regions (e.g., Kaliningrad, Yaroslavl, Moscow (Russia)) (Lentz, 1897; Plavilstchikov, 1936) are still unproven. More recent (since 2000) northernmost actual records are known from Mordovia (Russia) (Ruchin, 


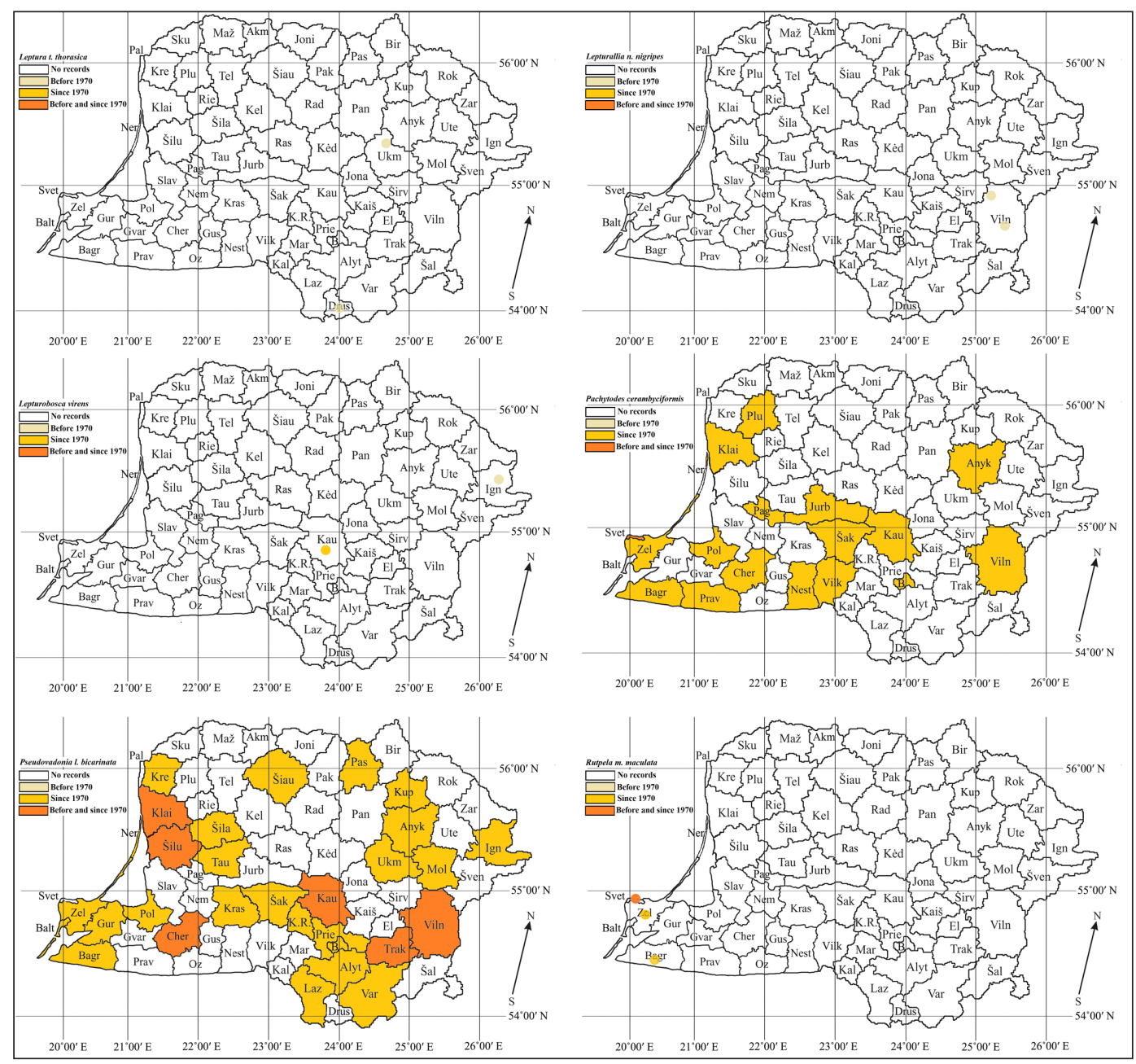

Fig. 5. Maps of distribution of Leptura t. thoracica, Lepturalia n. nigripes, Lepturobosca virens, Pachytodes cerambyciformis, Pseudovadonia l. bicarinata and Rutpela m. maculata (Coleoptera: Cerambycidae: Lepturinae) in the south-eastern Baltic region

Egorov, 2018). The southern border goes through the Iberian, Apennine, and Balkan peninsulas, Anatolia and the Caucasus; also, this species is known from the north-western provinces of Siria and Iran.

Notes on biology. The life cycle and host plants are similar to those of P. cerambyciformis, but according to Švácha (1989), P. erraticus chooses dryer and warmer habitats.

Local occurrence and phenology. No actual information in the region.

Comments. The single historical record from KR [Bagr: Lüdwigsort] is 140 years old (Lentz, 1879) and can be interpreted as an occasional sighting in the past or a misidentification (confusion with the widely distributed and variable in elytral colouring $P$. cerambyciformis or very similar in elytral pattern Judolia sexmaculata seems to be possible).

\section{Genus Pedostrangalia Sokolov, 1897}

旁 $P$. (s. str.) revestita (Linnaeus, 1767)

Examined actual data. Absent. No material is available from LT and KR.

Published local records. LT: Tamutis et al., 2011, as expected.

General distribution. The species is distributed in Europe from Portugal and Great Britain to the Balkan Peninsula, western Ukraine, Poland, and Sweden. Although it is widely distributed in south-western Europe, it is rarely observed. 
Notes on biology. Larvae develop in dead parts of living trees, usually in the places between dead and still living tissues, during a period of two or three years. Most preferred hosts are sparsely growing Quercus, Fagus, Ulmus, Acer, Juglans, Populus, and Betula. Pupation takes place in wood in the spring. Adults emerge in May or June; they are predominantly diurnal, visit fresh juicy wounds of trees and blossom of Cornus, Crataegus, Prunus, or other bushes or trees.

Local occurrence and phenology. Absent.

Comments. The species is recorded from southern Sweden and eastern Poland, so its occurrence is possible in the region. IUCN Red List Category (EU) - VU.

\section{Genus Pseudovadonia Lobanov, Danilevs- ky, Murzin, 1981 \\ P. livida bicarinata (Arnold, 1869)}

Examined actual data. LT: Alyt: Obelija, 25.06.1980, 1, VUst; Takniškiai, 26.06.2020, 1 (Ф), JT; Anyk: Traupis, 21.06.2020, 1 (C), SO; B: Šilèngirè, 20.06.2009, 1 (Ф), GS; Ign: Ignalina, 09-23.07.1979, 4, VUst; K.R.: Jūrè, 25.06.1983, 3, RF; Kau: Braziūkai, 26.06.2011, 1, VT; ibidem, 30.05-29.06.2018, 2, VT; Ežerèlis, 06.08.1982, 1, RF; Girionys, 09.07.1085, 1, RF; Jiesios kraštovaizdžio draustinis, 08.07.1983, 2, RF; ibidem, 26.06.1997, 2, RF; ibidem, 02-24.06.2000, 3, RF; Dievogala (Palankiai), 01-19.06.1936, 2, PRé; Karmèlavos miškas, 22.07.2004, 1, VI; Kaunas, 29.06.1969, 1, EG; ibidem, 20.07.1973, 2, EG; ibidem, 14.05.1983, 2, RF; ibidem, 17.06.2018, 1 (D), RF; Kuras, 11.07.2019, 2, VT; Pažaislis, 18.07.1981, 2, RF; Ringovès entomologinis draustinis, 08.06.1990, 1, RF; Klai: Giruliai, 29.05.1985, 1, SK; Šaipiai, 29.07.2004, 1, PI; Nemirseta, 29.06.2006, 1, PI; Smiltynè, 30.06.2007, 1, DSt; Kret: Darbènai, 17.06.2020, in copula on Knautia arvensis, 2, PR; Kup: Paketuriai, 20.06.1995, 1, RP; Laz: Straigiai, 24.06.2020, 3 (C), col. unknown; Mol: Drąsenai, 21.06.2020, 1 (), MK; Šnieriškès, 07.07.1994, 1, VT; Ner: Didysis Preilos ragas, 21.06.2002, 2, RF; Grobšto gamtos rezervatas, 20.06.2002, 4, RF; Juodkrantè, 06.07.2005, 4, RF; ibidem, 24.06.2007, 1, RF; ibidem, 18.07.2012, 1, RF;
Pervalka, 20.06.2002, 2, RF; Preila, 02.07.2007, 1, VT; Pas: Pajiešmenių botaninis-zoologinis draustinis, 02.07.2007, 4, VB; Rimkūnų miškas, 17.07.2006, 1, VB; Šimoniai, 27.07.2005, 1, VB; Prie: Bačkininkų miškas, 01.07.1984, 3, RF; Šak: miškas Juškinè, 15.07.2009, 1, RF; Tervydoniai, 23.06.2013, 1, RF; Šiau: Einoraičiai, 15.07.1998, 1, RF; Slydžiai, 20-29.06.1998, 2, VT; ibidem, 16.07.2005, 1, VT; ibidem, 20.06.2008, 1, VT; ibidem, 19.07.2012, 1, VT; Šila: Požerè, 13.07.1976, 1, AMa; Šilu: Kintai, 21.07.1957, 1, SP; Žemaičių Naumiestis, 12.06.2020, 1 (6), KK; Tau: Viešvilès valstybinis gamtinis rezervatas, 20.07.2000, 1, VU; Trak: Jovariškès, 27.06.2020, 1 (Ф), PS; Kariotiškis, 13.06.1953, 1, SP; Trakai, 11.08.1929, 1, AP; Ukm: Dukstynos entomologinis draustinis, 20.06.1977, 1, GŠ; Var: Biniūnai (Baudzieriškis), 22.06.1939, AP; Čepkelių valstybinis gamtinis rezervatas, 18.06.1989, 1, AM; Paručiai, 11.07.2020, 1 (D), JM; Ūlos kraštovaizdžio draustinis, 22.06.1985; 3, RF; Varèna, 21.06.1995, 1, VT; Viln: Veliučionys, -.07.1971, AMa, Vilnius (Šeškinè), 23.06.2019, 1 (Ф), AJu; Vilnius (Viršuliškès), 26.06.2020, 1 (D), VK; Vilnius (Žirmūnai), 19.07.2019, 1 (D), JM; KR: Bagr: Ul'ianovka, 07.06.2010, 1, VA; Novomoskovskoe, 27.06.2010, 1 (D), VA; Ladushkin, 25.06.2019, 1, VA; Balt: 3 km W Primorsk, 21.06.2010, 1, VA; Cher: $1 \mathrm{~km}$ E Cherniakhovsk, 02.06.2000, 1, VA; ibidem, 25.06.2006, 2, VA; Gur: $1 \mathrm{~km}$ W Kaliningrad, 14.06.2020, 2 (Ф), VA; Kras: Nikol'skoe, 02.06.2002, 1, VA; Pol: Fevral'skoe, 28.06.2020, 1 (Ф), VA; Zel: $23 \mathrm{~km}$ of the Curonian Spit, 19.06.2007, 1, VA; Kholmogorovka, 14.07.2007, 1, VA; Povarovka, 20.06.2019, 1, VA.

Published local records. LT: This species is ranked as common and noted as distributed in the Baltic Sea region, central and eastern parts of the country by Pileckis, Monsevičius (1997) (Anoplodera livida pecta Dan.). It was noted as a common species for the environs of Vilnius (Zawadzki, 1937 (Vadonia); Staniulisówna, 1939 (Leptura)). It also was reported from Klaipeda [Memel] (Bercio, Folwaczny, 1979; Ostrauskas, Tamutis, 2012). KR: Lentz, 1879 (Leptura); Bercio, Folwaczny, 1979 (Leptura); Alekseev, Sakhnov, 2002 (Anoplodera); Alekseev, 2006, 2007. 
General distribution. It is distributed from Ireland, Great Britain, Iberia to the Baikal region. Northwards, its distribution range reaches $60^{\circ} \mathrm{N}$ in Scandinavia and in Leningrad, Perm, and Kirov regions in European Russia. The species is widely distributed in southern Europe, and is also known in the Caucasus, Turkey, Iraq, and Iran (Özdikmen, Ali, 2017).

Notes on biology. The most comprehensive information on the biology of this species is presented by Burakowski (1979). He established that larvae develop in the soil humus layer and feed on fungal mycelium (Marasimus oreades) or dead roots of grasses; pupation in spring. They apparently prefer dry habitats, sparcely covered with low grasses. The life cycle lasts two years. Adults emerge in May or June; they are diurnal and widely anthophilous. Flowers of fluorescent yellow colour seem to be most attractive to adult P. livida (Toshova et al., 2016).

Local occurrence and phenology. This species is widely distributed and common in the region; the adults are observed mostly in relatively dry grasslands on blossoms of Asteraceae. Recorded from 30 districts (Fig. 5); the maximum of recorded adults was in June, the earliest record on 14 May, the latest on 11 August.

Comments. The species is polymorphic. Currently, seven subspecies are designated according to their morphological characters, mainly on setation of the pronotum and colouration of legs, elytra, and abdomen, and some peculiarities of geographical distribution (Danilevsky, 2014, 2019; Özdikmen, 2015). Four of them occur in Europe; however, the distribution areas of two subspecies, P. livida livida and P. livida bicarinata (Arnold, 1869), are not completely designated. Both subspecies are noted for Poland and Belarus, but only a single species, P. livida bicarinata, is noted for the Baltic countries (Danilevsky, 2019). Indeed, the characters for distinguishing reliably the specimens of these subspecies are not strong enough, because they are based only on setation of the pronotum and colouration of the legs (Danilevsky, 2014; Ösdikmen, 2015). All of our revised specimens from KR have a black abdomen and dark legs; however, some specimens from Lithuanian have a reddish abdomen and light-coloured (yellow to brown) legs. The notification of subspecies P. (l.) pecta Daniel, Daniel, 1891 for LT by Pileckis, Monsevičius (1997) (Anoplodera) is erroneous, because this subspecies is regarded to be endemic for northern Italy (Danilevsky, 2014).

\section{Genus Rutpela Nakane, Ohbayashi, 1957}

$R$. maculata maculata (Poda, 1761)

Examined actual data. LT: no actual material; KR: Bagr: $1 \mathrm{~km}$ W Kamenka, 15.06.2019, 2, VA; Svet: W Svetlogorsk, 05.08.1996, 2, VA; ibidem, 18.07.2020, 2 (1), VA; Otradnoe, 30.06.2006, 1, VA; ibidem, 03.07.2006, 1, VA; ibidem, 30.06.2010, 1, VA; ibidem, 01.07.2010, 1 (6), VA; ibidem, 28.06.2011, 1 (Ф), VA; Maiskii, 13.06.2019, 2 (Ф), VA; Zel: 3 km NW Medvedevka, 04.07.2010, 1, VA; ibidem, 24.07.2012, 1 (Ф), VA.

Published local records. LT: First notification of this species was made by Pileckis (1976) without actual data; later it was noted for the central part of the country and designated to the category "very rare" by Pileckis, Monsevičius (1997). KR: Lentz, 1879 (Strangalia armata calcarata Fabr.); Bercio, Folwaczny, 1979 (Strangalia); Alekseev, Sakhnov, 2002 (Leptura); Alekseev, 2007.

General distribution. It is distributed from Portugal, Great Britain to the Urals, and Kazakhstan. The northern border of its distribution range goes through southern Scandinavia, Finland, and the Moscow region. The nominative subspecies is widely distributed in central and southern Europe; however, subspecies $R$. maculata manca Schaufuss, 1863 is known in the southernmost European countries, the Caucasus, Turkey, Siria, and Iran.

Notes on biology. The species is polyphagous on both deciduous and coniferous trees but prefers Quercus and other deciduous trees and is rarely found on coniferous ones. The larvae develop in moist decaying wood ("white rot") of fallen stems, branches, or roots over a period of two to three years. Adults appear in May-July; they are diurnal and anthophilous, feeding mostly on the blossom of Apiaceae and Rosaceae. 
Local occurrence and phenology. The species is locally distributed (only in the western part of the region) and is rare in KR. The imagos were observed feeding on flowers of different Apiaceae and Asteraceae from 13 June until 5 August in three districts (Fig. 5).

Comments. A single actual record of this species for LT is mentioned in Pileckis's manual index card: "Raudondvaris, 29.06.1971, leg. R. Gaidys". Unfortunately, we could not confirm this record because it lacked a voucher specimen. Its persistent location in the forest of the northern part of the Sambian Peninsula for over 140 years is interesting. Current known localities of the species in KR are no more than $25 \mathrm{~km}$ away from the Baltic Sea or the Kaliningrad Gulf. It is possibly an endangered species in the region and requires protection. IUCN Red List Category (EU) - LC.

\section{Genus Stenurella Villiers, 1974}

\section{S. (Nigrostenurella) nigra nigra (Linnaeus, 1758)}

Examined actual data. LT: Akm: Kamanu valstybinis gamtinis rezervatas, 24.06.1980, 2, VM; Jona: Didžiojo raisto miškas, 13.06.2016, 1, VI; K.R.: Jūrès miškas, 25.05.2000, 2, RF; Pilypai, 30.05.2018, in copula, 2 (D), EVi; Kaiš: Grabuciškès, 06.06.2019, 1 (Ф), JM; Kau: Braziūkai, 07.06.2020, 2, VT; Braziūkų miškas, 20.06.2011, 1, VT; ibidem, 06.06.2011, 1, VT; ibidem, 15.06.2019, 1, VT; Dubravos miškas, 19.07.1978, 1, RF; ibidem, 20.06.1988, 1, RF; ibidem, 28.06.1998, 2, RF; Karmèlavos miškas, 19.06.2004, 1, VI; ibidem, 15-20.06.2005, 3, VI; Kaunas (Kleboniškio miškas), 05.06.2016, 1, VI; Turžènų miškas, 14.06.2014, 2, VI; Pan: Vosniūnų miškas, 13.06.1995, 1. RP; Prie: Papilvis, 28.06.2009, 1 (Ф), GS; Šak: miškas Juškinè, 15.06.2005, 1, RF; ibidem, 29.06.2008, 1, RF; ibidem, 29.06.2014, 2, RF; ibidem, 02.07.2015, 2, RF; Novaraistis, 06.06.2000, 1, RF; Tervydoniai, 13.06.2020, 1 (C), RF; Tau: Antegluonis, 30.07.2004, 1, RF; Var: Marcinkonys, 21.06.1978, 1, PI; KR: Bagr: 1 km E Ladushkin, 08.06.2009, 1, VA; ibidem, 11.07.2017, 1 (6), VA; 1 km W Kamenka, 15.06.2019, 1, VA; 1 km W Bogdanovka, 19.06.2020, 1 (6), VA; Ul'ianovka, 13.06.2020, 1
(C), VA; Balt: 3 km W Primorsk, 01.07.2020, 1 (Ф), VA; Cher: 3 km W Krasnovka, 17.06.1993, 1, VA; Gur: 3 km N Chkalovsk, 07.06.2016, 1 (6), VA; Gvar: 3 km S Ozerki, 02.06.2020, 1 (D), VA; Svet: Otradnoe, 29.06.2006, 1, VA; Svetlogorsk, 10.06.2007, 1, VA; Zel: Riabinovka, 22.05.2002, 1, VA; ibidem, 19.06.2002, 1, VA; ibidem, 20.06.2010, 1 (Ф), VA; Svinoe Bog, 07.07.2009, 1, VA; 3 km S Grachevka, 06.06.2010, 1, VA; $1 \mathrm{~km}$ SW Izhevskoe, 03.07.2015, 1, VA; $2 \mathrm{~km}$ NE Kostrovo, 09.06.2020, 1 (C), VA; Kremnevo, 12.07.2020, 1 (D), VA.

Published local records. LT: This species is ranked as rare and noted as distributed in the central and eastern part of LT by Pileckis, Monsevičius (1997) (Leptura, Strangalia). The actual faunistic information was given on occurrence of this species in Druskininkai (Pileckis, 1963) (Strangalia) and Kaunas (Inokaitis, 2004) districts. KR: Lentz, 1879 (Strangalia); Bercio, Folwaczny, 1979 (Strangalia); Alekseev, Sakhnov, 2002 (Leptura); Alekseev, 2007.

General distribution. It is distributed from south-western Iberia, Great Britain to the Urals. The northern border of its distribution range stretches across the southern provinces of Norway, Denmark, Sweden, Estonia, Finland (old data only), and the Tver oblast (Russia, old data only). The nominative subspecies is widely known from southern Europe, while $S$. (N.) nigra moesta Danilevsky, 2013 is representative of the fauna of the Caucasus region, Anatolia, and northern Iran (Danilevsky, 2014).

Notes on biology. The species is polyphagous on deciduous trees, mostly Quercus, Betula, Carpinus, Corylus, Ulmus, Frangula, Rosa, and Robinia. The larvae develop in relatively dry decaying wood of thin branches or stems during a period of at least two years; pupation in wood. Adults appear in May or June; they are diurnal and anthophilous, and feed mostly on the blossom of Apiaceae, Rosaceae, Asteraceae, and Cornaceae.

Local occurrence and phenology. This species is more common in KR than in LT. Recorded from 18 districts (Fig. 6); the maximum of recorded adults was in June, the earliest record on 22 May, the latest on 30 July. 


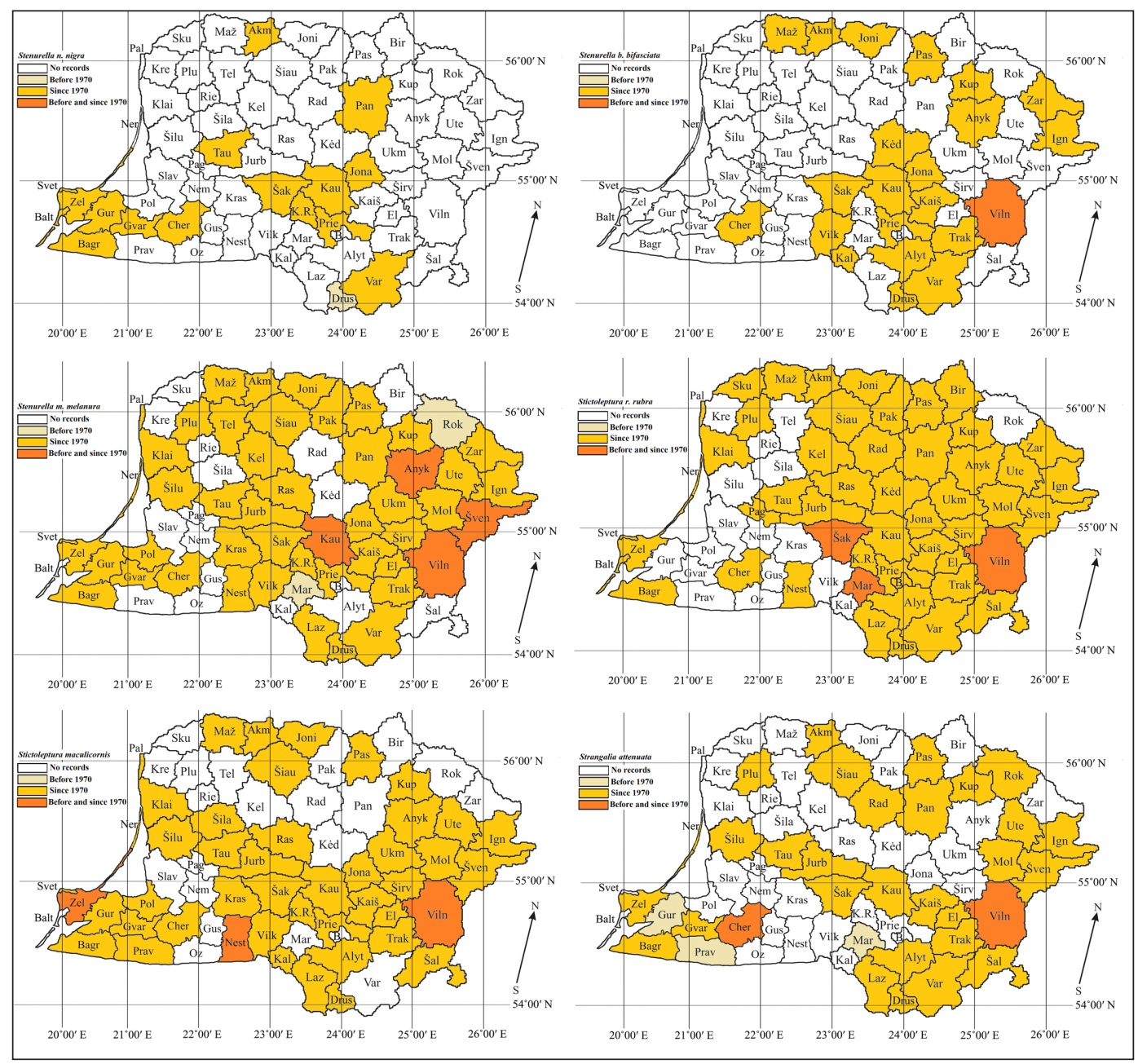

Fig. 6. Maps of distribution of Stenurella n. nigra, Stenurella b. bifasciata, Stenurella m. melanura, Stictoleptura r. rubra, Stictoleptura m. maculicornis and Strangalia attenuata (Coleoptera: Cerambycidae: Lepturinae) in the south-eastern Baltic region

Comments. IUCN Red List Category (EU) - LC.

\section{S. (Priscostenurella) bifasciata bifasciata} (O. F. Muller, 1776)

Examined actual data. LT: $A k m$ : Akmenè, 17.06.2020, 1 (⿻丅), AK; Alyt: Strielčiai, 05.07.2020, 1 (D), PK; Vidzgirio botaninis draustinis, 11.07.2018, 1, RF; Anyk: Traupis, 15.07.2020, 1 (D), SO; Drus: Gerdašiai, 12.07.2000, 1, PI; Ign: Gineitiškis, 15.07.1997, 1, VT; Ignalina, 01-18.07.1979, 2, VUst; Jona: Didžiojo raisto miškas, 02.06.2005, 1, VI; Joni: Rukuižiai, 07.07.2002, 2, RB; Kaiš: Kruonis, 06.07.2002, 1, AM; Strošiūnų miškas, 12.07.2009, 2, VB; ibidem, 04-25.07.2009, 3, DSt; Triliškès,
16.07.2007, 1, DSt; Kal: Liubavas, 07.07.2018, 1 (D), GS; Orija, 02.07.2020, 2 (D), VP; Pasiekos, 11.07.2020, in copula, 2 (Ф), AK; Trakenu miškas, 12.07.2020, 1 (Ф), AKu; Kau: Braziūkai, 28.08.2020, 1, VT; Karmèlava, 29.07.2005, 1, VI; Kaunas (Lampèdžiai), 11.07.2020, RS; Kuras, 11.07.2019, 6, on blooms of Achilea, VT; Panemunès šilo parkas, 29.06.2016, 1, RF; Pažaislio šilas, 07-16.07.2011, 2 (C), GS; Pilènų miškas, 27.06.2010, 1, VI; Turžènų miškas, 08-17.07.2000, 6, VI; Kèd: Pašilių miškas, 14.07.2020, 1 (), KV; Kup: Uoginiai, 21.07.1998, 1 RP; Stirniškiai, 20.07.2020, 1 (D), AV; Maž: Leckava, 25.07.2009, 1, DM; Pas: Dūdiškiai, 07.08.2020, 1 (ब), JM; Prie: Bačkininkų miškas, 01.07.1984, 1, RF; Šak: 
miškas Juškinè, 03.08.2016, 1, RF; Trak: Trakai, 09.07.2020, 1 (D), obs. unknown; Var: Glūko miškas, 11.07.2020, 2 (Ф), JM; Grybaulios miškas, 03.07.2019, 2, KM; miškas Ežeraičiai, 02.07.2016, 1 (D), ŽP; Navikai, 04.08.2019, 1 (D), GM; Puvočiai, 12.07.2003, 1, APe; Vilk: Pajevonys, 11.07.2003, 1, RF; Viln: Elniakampio miškas, 30.06.2018, 1 (Ф), GM; Maišiagala (Kalniškès), 12.07.2009, 2, PI; Paberžè (Medyna), -.-.1892, 1, BH; Rastinènai, 31.07.2017, 1 (Ф), GM; Rukainių miškas, 29.06.2012, 1 (C), DB; Vilnius (Baltupiai), 23.07.2017, 1 (C), JM; Vilnius (Jočionys), 03.08.2020, in copula, 1 (⿻), obs. unknown; Vilnius (Šeškinè), 26.06.2019, 1 (D), AJu; Vilnius (Vingio parkas), 19.06.2003, 1, SS; Vilnius (Visoriai), 13.07.2020, 1 (Ф), GČ; Zar: Smalvykštis lake environs, 24.07.1998, 3, RF; Zarasai, 12.07.2012, 1, V.T.; KR: Cher: 1 km E Cherniakhovsk, 01.07.1993, 1, V.A.; ibidem, 25.06.2006, 2, VA; ibidem, 16.06.2008, 1, VA; ibidem, 11.06.2018, 2 (D), VA.

Published local records. LT: This species is ranked as rare and noted as distributed throughout the country, except its western part, by Pileckis, Monsevičius (1997) (Leptura, Strangalia). The actual faunistic information was given on the occurrence of this species in Ignalina (Ostrauskas, 2020) Marijampole (Pileckis, Monsevičius, 1997) (Leptura, Strangalia), and Vilnius (Zawadzki, 1936; Staniulisowna, 1939) (Strangalia) districts. KR: Lentz, 1879 (Strangalia); Bercio, Folwaczny, 1979 (Strangalia); Alekseev, Sakhnov, 2002 (Leptura); Alekseev, 2006, 2007.

General distribution. It is widely distributed throughout Palearctic Eurasia from Portugal to the Baikal region (Siberia). The southern part of Estonia and the Moscow region (Russia) (Nikitsky et al., 1996) are the northernmost areas of the distribution of this species. Southwards, it is known in Sicily (southern Italy) (Sama, Rapuzzi, 2011), Greece (Plewa et al., 2011), Antalya (southern Turkey), Iraq, Iran, Lebanon, and Syria.

Notes on biology. The species is polyphagous. The larvae develop in dead wood of thin stems or stumps. Its life cycle is two years. $\mathrm{Pu}$ pation takes place in wood during spring; adults emerge in late May-June; they are diurnal and widely anthophilous.

Local occurrence and phenology. This species is widely distributed and common in LT; however, it is surprisingly local and rare in KR. Recorded from 23 districts (Fig. 6); the maximum of recorded adults was in July, the earliest record on 02 June, the latest on 28 August.

Comments. The type specimen of this species was collected in Denmark (Müller, 1776); however, this country was not included in the distribution range of this species (Bily, Mehl, 1989; Sifverberg, 2010; Danilevsky, 2019). IUCN Red List Category (EU) - LC.

\section{S. (s. str.) melanura melanura (Linnaeus, 1758)}

Examined actual data. LT: Akm: Kamanu valstybinis gamtinis rezervatas, 02.07.1980, 3, VM; Karniškių telmologinis draustinis, 29.07.1991, 1, VM; Anyk: Katlèriai, 19.07.1985, 4, SK; Mickūnai, 18.07.2020, 1 (Ф), RGa; Traupis, 27.06.2020, 1 (Ф), SO; Žudžgalys, 29.07.2020, 1 (Ф), AV; Drus: Gerdašiai, 13.08.1996, 1, RF; Latežeris, 13.06.1985, 5, EG; Randamonys, 14.06.1985, 1, EG; Žiogeliai, 10.07.2017, 2 VI; El: Panerių I miškas, 14.08.2017, 1 (D), AK; ibidem, 04.07.2020, 1 (C), JM; Zabarija, 27.07.2017, 1 (Ф), AK; Ign: Gineitiškis, 26.07.1997, 2, VT; Ignalina, 14-23.07.1979, 7, VUst; Jona: Didžiojo raisto miškas, 27.06.2001, 1, RF; Joni: Daukšiai, 07.07.2002, 1, RB; Girdžiūnai, 15.06.2000, 1, RB; ibidem, 15.07.2003, 1, RB; Juodeikiai, 28.06.2005, 2, RB; Nemeikšiai, 28.06.1999, 1, RB; Rukuižiai, 07.07.2002, 2, RB; Satkūnai, 21.06.1998, 1, RB; Skilvioniai, 29.06.2004, 1, RB; Veršiai, 21.06.2005, 1, RB; Jurb: Viešvilè, 17.06.1957, 1, SP; Viešvilès valstybinis gamtinis rezervatas, 18-20.07.2000, $3 \mathrm{VU}$; ibidem, 02.08.2000, 1, VU; ibidem, 11.07.2001, 2 VU; ibidem, 24.07.2001, 2, RF; ibidem, 12.06.2008, 1, VT; ibidem, 31.07.2008, 6, VT; K.R.: Beržiniškès miškas, 07.07.2018, 4, VT; Braziūkų miškas,13.08.2005, 1, VT; ibidem, 15.06.2011, 5, VT; ibidem, 22.06.2018, 1, VT; ibidem, 19.06.2019, 4, VT; Jūrè, 25.06.1983, 5, RF; ibidem, 05.07.1985, 2, RF; ibidem, 26.06.1994, 1, AM; Kajackai, 13.07.1985, 1, RF; Kazlų Rūda, 
20-25.06.1955, 4, EG; Kaiš: Strošiūnų miškas, 20.06.2007, 1, DSt; ibidem, 05-08.07.2008, 3, DSt; ibidem, 03-25. 07.2009, 4, DSt; Triliškès, 18.07.2007, 1, DSt; Kau: Braziūkai, 01.07.2009, 1, VT; Braziūkų miškas, 19.07.2011, 1, VT; Dievogala (Palankiai), 18.06.1934, 1, PRé; ibidem, 14.07.1935, 1, PRè; ibidem, 24.05.1937, 1, PRé; Dubravos miškas, 25-27.06.1959, 3, SP; ibidem, 28.06.1981, 4, RF; ibidem, 10-12.07.2001, 5, RF; ibidem, 30.06.1984, 1, RF; ibidem., 25.07.1985, 1, RF; ibidem, 08.06.1986, 1, RF; ibidem, 01.07.1992, 1, RF; ibidem, 21.07.2000, 1, RF; Dubravos rezervatinè apyrubè, 23.06.2007, 1, AM; Ežerèlis, 11.06.2002, 1 RF; Gervenupis, 28.07.1967, 1, EG; ibidem, 30.06.1968, 1, EG; ibidem, 06-10.06.1971, 9, EG; ibidem, 1430.06.1972, 4, EG; ibidem, 16-29.06.1974, 3, EG, ibidem, 28.07.1974, 6, EG; ibidem, 15.06.1976, 2 EG; Girionys, 20.08.1969, 1, EG; Jiesios kraštovaizdžio draustinis, 21.06.1981, 1, RF; ibidem, 17.06.2000, 1, RF; Karmèlava, 28.06.2003, 1, VI; ibidem, 26.06.2005, 1, VI, ibidem, 26.07.2009, 1, VI; Kaunas, 20.07.1973, 2, EG; Kaunas (Ąžuolyno parkas), 06.07.2009, 2 (D), GS; Kaunas (Eiguliai), 09.06.2020, 1 (D), GV; Kaunas (Kleboniškio miškas), 17.06.2002, 1, VI; ibidem, 26.06.2006, 1, VI; ibidem, 27.07.2008, 1, VI; ibidem, 05.07.2016, 1, VI; Kulautuva, 06.07.2002, 1, VT; Kuras, 11.07.2019, 2, VT; Laumėnai, 18.06.2008, 1, VI; Lomankos miškas, 17.07.2015, 1, VI; Meištinès miškas, 16.06.2019, 3, VT; Nevėžio kraštovaizdžio draustinis, 23.06.2009, 1, RF; Patamulšèlis, 08.07.2017, 3, VI; Pažaislis, 18.07.1981, 1, RF; Raudondvaris, 10.06.1967, 1, EG; ibidem, 10.07.1967, 1, EG; ibidem, 15.06.1970, 2, EG; ibidem, 25.06.1975, 2, EG; Turžènų miškas, 05.07.2010, 1, VI; Varluvos miškas. 04.07.2007, 1, VT; Zapyškio miškas, 16.06.2019, 4, VT; Kel: Šonos miškas, 24.07.2011, 1, VT; Klai: Melnragè, 27.06.1989, 1, SK; Smiltynè, 30.06.2007, 1, DSt; Kup: Šimonių miškas, 20.07.1991, 2, RP; Laz: Babrų miškas, 25.07.2020, 1 (ब), AB; Maž: Kiminiškè, 02.08.1991, 4, VM; Mol: Molètai, 29.06.1964, 1, EG; ibidem, 16.07.1969, 2, EG; ibidem, 30.06.1979, 1, EG; Pašulniškių miškas, 15.07.2018, 1 ('), APaš; Stirniai, 10.07.1965, 1, EG; Ner: Juodkrantè, 10.08.1981, 1, EG; ibidem,
25.06.1988, 1, RF; ibidem, 15.07.1998, 1, AG; ibidem, 09.07.2000, 1, RF; ibidem, 09.07.2004, 1, RF; ibidem, 08.07.2017, 1 (Ф), KM; Naglių gamtinis rezervatas, 04.07.2005, 2, RF; Pak: Kvartos miškas, 20.07.1957, 2, SP; Pal: Manciškè, 14-15.06.2001, 2, RF; Palanga, 06.09.1978, 1, VUst; ibidem, 25.06.2020, 1 (Ф), GPe; Pan: Paliepiai, 05.08.2020. 1 (D), JM; Pas: Aukštagojis, 24.06.2006, 3, VB; Moliūnų miškas, 02.08.2005, 1, VB; ibidem, 09.08.2006, 1, VB; Rinkūnų miškas, 17.07.2006, 1, VB; ibidem, 27.07.2007, 1, VB; Žadeikių miškas, 21.07.2006, 1, VB; Plu: Grigaičių miškas, 02.09.1998, 1, AG; ibidem, 30.06.2019, 1 (D), TG; Prie: Bačkininkų miškas, 25.06.1984, 1, RF; Papilvis, 27.07.2008, 1 (D), GS; Ras: Viduklès geležinkelio stotis, 17.06.1999, 1, VI; Rok: Ignotiškis, 02.08.1986, 1, EG; Šak: miškas Juškine, 18.06.2000, 2, RF; ibidem, 21.07.2009, 1 (D), RF; ibidem, 09.07.2017, 1, RF; Jadagoniai, 18.07.1999, 1, R. Braškys; Tervydoniai, 01.06.2014, 1, RF; Šiau: Blužgalis, 20.07.2002, 3, VT; Einoraičiai, 15.07.1998, 1, RF; Paežerių miškas, 16.07.1998, 1, RF; Paraudžių miškas, 27.07.2019, 2, RF; Šilu: Žalgirių miškas, 18.06.2002, 2, RF; Širv: Astruvkos miškas, 12.07.2016, 1, VI; Šven: Kanio raisto botaninis-zoologinis draustinis, 11.08.1991, 1, VM; Labanoro giria, 1013.07.1965, 6, EG; Laukagalis, 16.06.2018, 1 (D), GM; Pakretuonès miškas, 19.07.1979, 1, VUst; Sariai, 30.06.2020, 3 (Ф), obs. unknown; Tau: Antegluonis, 30.07.2004, 1, RF; Viešvilès valstybinis gamtinis rezervatas, 12.06.1992, 2, VM; Tel: Derkintai, 11.07.1996, 4, VM; Trak: Plomènai. 30.07.1998, 1, PI; Ropejų miškas, 28.06.2020, 2 (6), AJu; Tolkiškès, 03-10.07.1978, 6, VUst; Ukm: miškas Dukstyna, 20.06.1977, 1, GŠ; Ute: Kvykliai, 24.06.2018, 1 (D), ŽP; miškas Skaistašilis, 06.07.2020, 1 (Ф), VBu; Saldutiškis, 06.07.1998, 1, VT; Utena, 15.06.1965, 1, EG; Var: Čepkelių valstybinis gamtinis rezervatas, 26.07.1983, 4, VM; Grybaulios miškas, 30.06.2019, 2 (D), GM; ibidem, 03.07.2019, 2, KM; Jablanavas, 31.07.1998, 1, AG; Perloja, 2025.07.1981, 2, VUst; Puvočiai, 14.07.1974, 1, VUst; ibidem, 02.07.1978, 1, VUst; ibidem, 1921.07.1979, 2, VUst; ibidem, 05-23.07.1983, 27, VUst; ibidem, 05-22.07.1984, 5, VUst; ibidem, 
15-18.07.1986, 2, VUst; ibidem, 18.07.1991, 1, VUst; Vazgirdonys, 11.07.2020, 2 (6), JM; Vilk: Pajevonys, 11.07.2003, 1, RF; Viln: Baltoji Vokè, 14.07.2020, 1 (D), GSt; Kalnuotè VII, 05.07.2009, 1 (D), DB; Maišiagala (Kalniškès), 09.07.2012, 4, PI; Paberžè (Medyna), -.-.1892, 1, BH; Nemenčinè, 19.06.1982, 1, VUst; Rūkainių miškas, 19008.2012, 1 (C), DB; Veliučionys, 15.06.1971, 1, AMa; ibidem, 07.07.1971, 2, AMa; Vilnius (Lazdynai), 14.07.2020, 2 (Ф), obs. unknown; Vilnius (Šeškinè), 22.06.2019, 1 (D), JM; Vilnius (Verkių miškas), 19.06.2019, 2 (D), AJu; Zar: Dusetos, 17-23.07.1979, 5, VUst; Smalvykštis lake environs, 24.07.1998, 1, RF; Zarasai, 12.07.2012, 1, VT; KR: Bagr: 2 km S Novomoskovskoe, 07.07.2009, 3, VA; ibidem, 27.06.2010, 3 (6), VA; Ladushkin, 02.07.2014, 1 (Ф), VA; ibidem, 27.06.2010, 1, VA; Cher: Pushkarevo, 26.06.2006, 1, VA; Gur: Kaliningrad, 03.06.2007, 1, VA; 3 km Chkalovsk, 08.07.2020, 2 (D), VA; Gvar: 4 km S Ozerki, 09.07.2018, 2 (D), VA; Kras: Dolzhanskoe, 28.06.1997, 3, VA; ibidem, 01.07.1998, 1, NM; Pol: Sosnovka, 22.06.2010, 1, VA; ibidem, 12.06.2019, 2 (Ф), VA; Nest: 2 km NE Krasnoles'e, 08.06.2008, 2 (D), VA; Svet: Otradnoe, 29.06.2006, 1, VA; ibidem, 30.06.2010, 1 (D), VA; Svetlogorsk, 10.06.2007, 1, VA; Zel: 3 km W Riabinovka, 17.06.2001, 1, VA; ibidem, 21.06.2019, 1 (D), VA; Kolosovka, 18.07.2004, 1, VA; $2 \mathrm{~km}$ N Aleksandrovka, 22.06.2010, 1, VA; 3 km E Russkoe, 04.07.2010, 1, VA; 2 km W Povarovka, 20.06.2019,1, VA; $2 \mathrm{~km}$ NE Kostrovo, 30.05.2016, 1 (D), VA; ibidem, 18.06.2018, 2 (Ф), VA; Kremnevo, 12.07.2020, 1 (Ф), VA.

Published local records. LT: This species was ranked as very common and noted as distributed throughout the country, except the coastal region of the Baltic Sea, by Pileckis, Monsevičius (1997) (Leptura, Strangalia). The actual faunistic information was given on the occurrence of this species in Anykščiai, Marijampole, Kaunas (Ferenca, 2006) (Leptu$\mathrm{ra}$, Strangalia), Švenčionys (Mazurowa, Mazur, 1939) (Strangalia), Elektrènai, Kazlų Rūda, Trakai, and Vilnius districts (Ostrauskas, 2020). This species was reported as common and numerous in the environs of Vilnius during the pe- riod of 1922-1938 by Zawadzki (1937) (Strangalia), and Staniulisówna (1939) (Strangalia).

KR: Lentz, 1879 (Strangalia); Bercio, Folwaczny, 1979 (Strangalia); Alekseev, Sakhnov 2002 (Leptura); Alekseev, 2006, 2007.

General distribution. It is widely distributed throughout Palearctic Eurasia from Iberia, Great Britain to the Far East (Khabarovsk region). The distribution range reaches $67^{\circ} \mathrm{N}$ in Scandinavia and $63^{\circ} \mathrm{N}$ in European Russia. Southwards, it is known in the Calabria region (southern Italy), Greece, Antalya (southern Turkey), northern provinces of Iran, Mongolia, China, and Japan.

Notes on biology. The species is polyphagous on both deciduous and coniferous trees, with larvae inhabiting dead, moist, and decaying wood. It prefers thin, fallen, or slightly burred stems and branches or shallow roots; develops over two to three years. Pupation takes place in spring. The adults emerge mainly in June; they are diurnal and widely anthophilous.

Local occurrence and phenology. This species is widely distributed and common in the region. Recorded from 51 districts (Fig. 6); the maximum of recorded adults was in July, the earliest record on 24 of May, the latest on 02 September.

Comments. A single record of this species is noted on 28 April 1928 in Kaunas district by Alfonsas Palionis (Ferenca 2006: 201), but we doubt the correctness of this date. IUCN Red List Category (EU) - LC.

\section{Genus Stictoleptura Casey, 1924}

S. (Aredolpona) rubra rubra (Linnaeus, 1758)

Examined actual data. LT: Akm: Pakalupis, 07.07.2020, 1 (Ф), SSo; Rasteikiai, 23.07.1999, 1, RF; Alyt: Alytus, 06.07.2020, 1 (D), GČ; Junčionys, 01.08.2020, 1 (Ф), JT; Punios šilas, 06.08.2008, 2, RF; Anyk: Anykščiai, 04.08.2020, 1 (D), AR; Ažuožeriai, 25.07.2019, 1 (D), RGa; Katlèriai, 08.07.1987, 1, SK; Niūronys, 28.07.2019, 1, VT; ibidem, 25.07.2020, 1, VT; Traupis, 10.07.2020, 2 (Ф), SO; ibidem, 07.08.2020, 1 (D), SO; B: Škèvonys, 20.07.2020, 1 (Ф), PN; Bir: Ločiai, 19.07.2020, 1 (Ф), RR; 
Miegonys, -.08.1971, 1, AMa; Totoriai, 11.07.2020, 1 (क), VK; Drus: Gerdašiai, 13.07.1999, 1, RF; Grūto miškas, 29.07.2018, 1 (D), GPe; Vartamedis, 29.07.2018, 1 (()), KVa; Vilkanastrai, 22.07.2020, 1 (D), obs.unknown; Viečiūnų miškas, 02.08.2017, 1, VI; El: Baltamiškis, 14.08.2017, 1 (D), AK; Paaliosé, 04.07.2020, 1 (Ф), JM; Pylimai, 04.08.2019, 1 (Ф), AK; Ign: Ažvinčių gamtinis rezervatas, 19.0725.08.2013, "window" traps, 13, VT; Ignalina, 16-23.07.1979, 4, VUst; Mikalinès miškas, 07.08.2020, 1 (D), obs. unknown; miškas Didžiagiris, 07.09.2017, 1 (Ф) KM; Palūšè, 27.07. 2019, 1 (D), BŠ; Jona: Jonava, 06.07.2020, 1 (()), MŠ; Ručiūnai, 15.07.2019, 1 (D), JZ; Joni: Bariūnai, 22.07.2001, 1, RB; ibidem, 27.0731.08.2004, 2, RB; Daunoriškè, 23.07.1998, 1, RB; Mikaičiai, 09.06.2005, 1, RB; Plikiškiai, 22.07.2003, 1, RB; ibidem, 19.07.2018, 1, RB; Satkūnai, 19.07-08.08.1998, 3, RB; Šarkiai, 19.07.2019, 1, RB; Jurb: Viešvilès valstybinis gamtinis rezervatas, 31.07.2009, 1, RF; K.R.: Beržiniškès miškas, 07.07.2018, 1, VT; Braziūkų miškas, 15.06.2017, 1 VT; ibidem, 09.07.2018, 1, VT; Jūrè, 02.08.2020, 1, VT; Jūrès miškas, 01.08.1973, 1, EG; ibidem, 24.07.1974, 1, EG; ibidem, 19.07.1981, 4, RF; Kajackai, 11.06.1985, 1, RF; Kazlų Rūda, 3-5.08.1967, 3, EG; Skriaudžių miškas, 22.07.2018, 1 (6), VGl; Kaiš: Kruonis, 24.07.1976, 1, AM; Lomenos kraštovaizdžio draustinis, 15,05.1995, 1, AG; ibidem, 15.06.1995, 8, AG; ibidem, 15.07.1995, 9, AG; ibidem 15.08.1995, 9, AG; Strošiūnų miškas, 13.07.2008, 2, DSt; Triliškès, 23.07.2007, 1, DSt; ibidem, 11.08.2007, 1, DSt; ibidem, 28.07.2009, 1, DSt; Vaiguvos miškas, 30.06.2007, 1, AM; Kau: Akademija, 15.07.2004, 1, AMa; Biruliškès, 07.08.2020, 1 (Ф), GSt; Braziūkai, 18.08.2019, 1, VT; ibidem, 26.07.2020, 1 (Ф), JI; Ežerèlis, 17.06.1996, 1, VT; ibidem, 12.07.2015, 1 (C), VBr; Dievogala (Palankiai), 02.07.1934, 1, PRé; ibidem 11.07.1935, 1, PRé; ibidem, 30.05.1936, 7, PRè; Dubravos miškas, 11.07. 1977, 2, EG; ibidem, 25.07.1975, 1, RF; ibidem, 09.08.1981, 1, RF; ibidem, 03.07.1983, 1, RF; ibidem, 11.07.1984, 1, RF; ibidem, 12.08.1986, 1, RF; ibidem, 31.08.2016, 1, GSt; Garliava, 16.08.2020, 1 (Ф), AKv; Garliava (Pagiriai),
15.07.2011, 1, APa; Gervènupis, 09.07.1972, 1, EG; ibidem, 26.07.1978, 1, EG; Kačerginè, 22.06.1962, 1, EG; ibidem, 10.08.1966, 2, EG; ibidem, 17.07.1974, 1, EG; ibidem, 02.08.2020, 1 (Ф), RS; Kadagių slènis, 15.07.2020, 1 (Ф), EMi; Kamšos miškas, -.07.2004, 2, col. unknown; ibidem, $-.06 .2006,2$, col. unknown; ibidem, -.05.2008, 2, col. unkown; Kaunas, 20.07.1924, 1, TI; ibidem, 15.08.1935, 1, PR; Kaunas (Kleboniškio miškas), 26.07.2000, 2, VI; Kaunas (Panemunès šilo parkas), 07.04.2019, 1 larvae (C), GS; Kaunas (Petrašiūnai), 22.07.2017, 1 (Ф), GS; Kaunas (Vičiūnai), 11.06.1985, 1, col. unknown; Karmèlava, 25.07-24.08.2004, 5, VI; Kuras, 02.07.1963, 1, EG; Narèpai, 19.07.2005, 1, VT; Raudondvaris, 28.07.2007, 1, VI; Varluvos miškas, 10.06.1998, 1, VI; Kel: Šonos miškas, 24.07.2011, 1, VT; Kèd: Pelèdnagiai, 21.07.2019, 1 (D), KV; Klai: Karkle, 13.07.2019, 1 (D), AN; ibidem, 08.08.2020, 1 (D), JT; Klaipèda, 31.07. 2011, 1 (D), RGr; Smiltyne, 11-27.07.1984, 2, SK; ibidem, 16.07.1985, 1, SK; ibidem, 20.07. 2020, 1 (D), ŠP; Šernai, 20.07.1988, 2, SK; Kup: Mirabelio miškas, 05.07.1991, 1, RP; Stirniškiai, 29.07.2020, 1 (Ф), AV; Šimonių miškas, 21.07, 1991, 1, RP; Vèžionys, 05.07.2020, 1 (Ф), obs. unknown; Laz: Ivoškų miškas, 22.08.2004, 1, VUst; Mar: Buktos miškas, 03.08.2019, 1 (6), AŽ; Maž: Kiminiškè, 02.08. 1991, 1, VM; Plinkšès, 10.08.2020, 1 (D), AB; Mol: Aklušè, 05.08.1975, 1, VUst; Galuonis lake environs, 26.07.2020, 1 (D), obs. unknown; Molètai, 25.07.1968, 1, EG; ibidem, 02.08.1978, 1, EG; Saliniškis, 15.08.2017, 1, VT; Ner: Juodkrantè, 07.08.1981, 1, EG; ibidem, 09-10.08.1986, 2, EG; ibidem, 16.08.1998, 1, AG; ibidem, 12.08.2000, 1, RF; ibidem, 28.07.2014, 1, RF; ibidem, 21.07.2019, 1 (Ф), BK; Pervalka, 15.08.1983, 1, VUst; Preila, 20.07.2020, 1 (Ф), AS; Raganų kalnas, 19.07.2018, 1 (Ф), AL; Pag: Vilkyškiai, 17.07.2020, 1 (D), MG; Pak: Lauksodis, 22.07.1960, 1, col. unknown; Pal: Manciškè, 28.07.1976, 2, AMa; ibidem, 20.08.2011, 1, RF; Palanga, -.06-08.1921, 1, AP; ibidem, 25.07. 2018, 1 (D), PA; ibidem, 27.07.2020, 1 ((D), DS; Šventoji, 27.07.1976, 1, AMa; ibidem, 25.07. 1992, 1, OD; Pan: Panevėžys, 30.07.1983, 1, VUst; Pas: miškas Lepšynè, 24.07.2004, 1, VB; 
Moliūnų miškas, 09.08.2006, 2, VB; Plu: Plokštinės miškas, 12.08.2020, 3 (D), VT; Prie: Balbieriškio ąžuolynas, 15.08.2020, 2, VT; Rad: Linkaičiu miškas, 05.08.2020, 1 (D), RV; Ras: Sukūriškiai, 03.07.2020, 1 (D), PK; Viduklès geležinkelio stotis, 09-19.07.1999, 5, VI; Sku: Šaukliai, 13.07.2020, 1 (Ф), obs. unknown; Šak: Kriūkai, 15-21.08.2005, 2, RF; miškas Juškinè, 25.07.2008, 2, RF; ibidem, 13.07.2012, 1 (6), RF; Sudargo miškas, 25.07.2020, 2 (C), LSt; Tervydoniai, 26.08.2011, 1 (C), RF; Veršiai, 18.07.2020, 1 (C), VA-K; Šal: Rūdininkų giria, 26.07.2003, 1, APe; Šalčininkai, 23.06.1933, 1, col. unknown; Šiau: Paraudžių miškas, 27.07.2019, 2, RF; Paširvio miškas, 10.07.2020, 1, VT; Vijoliai, 19.07.2018, 1 (D), TD; Širv: Bartuškio telmologinis draustinis, 15.07.2020, 1 (D), JM; Pajuodžiai, 25.07.2018, 1 (()), AJu; Širvintos, 16.07.1977, 1, VUst; Šven: Antasarè, 20.08.2020, 1 (), GU; ibidem, 22.08.2020, 1 (Ф), MU; Labanoro giria, Antaviešè, 23.06.2018, 1 (D), GM; miškas Baranava, 16.08.2020, 1 (Ф), KVi; Sariai, 25.08.2019, 1 (Ф), obs. unknown; Spenglo miškas, 26.07.2020, 1 (C), obs. unknown; Tau: Antegluonis, 30.07.2004, 1, RF; Artoji pelkè, 06.07.1992, 1, VU; ibidem, 10.08.2000, 1, VU; Pasalupis, 28.07.2016, 1, GS; Viešvilès valstybinis gamtinis rezervatas, 13.08.2004, 1, RF; ibidem, 31.07.2009, 1 (Ф), RF; Trak: Čiukiškès, 12.07.2020, 1 (Ф), MA; Tolkiškès, 05-07.07.1978, 2, VUst; Trakai, 04.07.1930, 1, NK; ibidem, -.06.1955, 2, SP; Ukm: Kertušas, 19.08.2020, 1 (D), KJ; Mašinių miškas, 05.08.2020, 1 (6), KJ; Verškainių miškas, 22.07.2019, 1 (Ф), KJ; Ute: Butiškiai, 19.07.2020, 1 (Ф), KŠ; Kušlių miškas, 19.07.2020, 1 (D), ŠP; Minčios miškas, 19.0625.07.2013, "window" trap, 1, VT; miškas Skaistašilis, 17.07.2020, 1 (Ф), VBu; Saldutiškis, 05.07.1958, 2, EG; Šimkūnai, 19.07.2020, 1 (C), JC; Var: Čepkelių valstybinis gamtinis rezervatas, 16.07.1971, 1, VUst; ibidem, 04.0606.07.1999, 1, DD; Dubninkas, 21.07.1983, 1, VUst; Gudu giria (Pogarenda), 24.07.1981, 3, VUst; Kapiniškès, 17.07.2017, 1, VI; Lavysas, 20.07.1995, 3, VT; Mančiagirè, 25.07.2020, 1 (C), JT; Mielupių miškas, 26.07.2018, 1 (C), TG; Musteikos miškas, 04.07.2019, 1, RF; ibidem, 29.07.2020, 1 (D), KK; Pamerkiai, 01.08.2020, 1
(Ф), TPo; Perloja, 23-25.07.1981, 3, VUst; Pošalčių miškas, 09.07.2020, 1 (T), AJu; Puvočiai, 21.07.1975, 1, VUst; ibidem, 18.06.1979, 1, VUst; ibidem, 14-27.07.1979, 14, VUst; ibidem, 14-21.07.1983, 12, VUst; ibidem, 08.07.1984, 1, VUst; ibidem, 14-16.07.1986, 3, VUst; Razumna, 17.07.2020, 1 (Ф), MJ; Trakiškiai, 30.06.2019, 1 (D), ŽP; Varèna, 21.08.1936, 1, col. unknown; Viln: Antavilio miškas, 22.07.2018, 1 (D), TD; Bubos, 28.07. 2020, 1 (()), EM; Dvarčionys, 28.07.2020, 1 (C), LK; Kairenų miškas, 31.07.2018, 1 (ד), APaš; Nemenčinè, 28.07.2019, 1 (Ф), JM; Paberžè (Medina), 11.07.1933, 1, BH; ibidem, 06.07. 1938, 1, BH; Rastinènai, 24.06.2019, 1 (ब), GM; Trakų Vokè, 21.07.2019, 1 (Ф), EČ; Veliučionys, -.08.1970, 2, AMa; Verkių miškas, 16.07.1976, 1, VUst; Vilnius, 21.07.2000, 1, J Kumiščia; Vilnius (Antakalnis), 01.08.2020, 1 (D), obs. unknown; Vilnius (Fabijoniškess), 18.06.2019, 2 (C), AJu; Vilnius (Vingio parkas), 03.08.2020, 1 (Ф), obs. unknown; Vilnius (Vismaliukai), 23.07.2018, 1 (ㅁ), APaš; Vilnius (Žvèrynas), 20.07.2020, 1 (6), IM; Zar: Degučiai, 15.08.2020, 1 (D), IN; Zarasai, 17-30.08.1937, 4, KA; KR: Balt: Pavlovo, 06.07-12.08.2015; 1, VA; Bagr: 1 km E Ladushkin, 11.07.2017, 1 (D), VA; Cher: $10 \mathrm{~km}$ NE Cherniakhovsk, 30.06.1993, 1, VA; Nest: Krasny Forest, 29.07.2003, 1, VA; Svet: 1 km W Svetlogorsk, 07.08.2019, 1 (D), VA; Zel: $23 \mathrm{~km}$ of the Curonian Spit, 19.06.2007, 1, VA; Rybachiy, 13.07.2010,2, VA; ibidem, 20.07.2015, 1, VA; Kostrovo, 30.06.2019, 1, VA; Svinoe Bog, 06.08.2020, 2 (D), VA.

Published local records. LT: This species is ranked as very common and noted as distributed throughout the country by Pileckis, Monsevičius (1997 (Anoplodera). However, the actual faunistic information was given on the occurrence of this species only in Šakiai (Pileckis, Monsevičius, 1997), Marijampole (Ferenca, 2006), Lazdijai (Ostrauskas, Tamutis, 2012), Elektrènai, Ignalina, and Švenčionys (Ostrauskas, 2020) (Corymbia) districts. This species was reported as common and numerous in the environs of Vilnius during the period of 1922-1938 by Zawadzki (1937); Staniulisówna (1939), Mazurowa, Mazur (1939) (Leptura). 
KR: Lentz, 1879 (Leptura rubra rubrotestacea Illig.); Bercio, Folwaczny, 1979 (Leptura); Alekseev \& Sakhnov 2002 (Anoplodera); Alekseev, 2006 (Corymbia); Alekseev, 2007.

General distribution. It is widely distributed throughout Palearctic Eurasia from southern Iberia and Great Britain to the Baikal region; northwards, it goes as far as Lapland (Finland) and Ukhta region (Russia). Its populations are restricted to mountainous areas in southern Europe. This species has not yet been recorded in the Crimean Peninsula and the Caucasus (Danilevsky, 2014, 2019); however, it is noted for Anatolia (Ösdikmen, 2007).

Notes on biology. The larvae of this species develop in dead decaying wood of various coniferous trees, but they prefer Pinus and Picea. Some authors additionally noted Quercus (Palm, 1959), Fagus (Bíly, Mehl, 1989; Ehnström, Axelsson, 2002), and some other deciduous trees (Švácha, 1989; Vitali, 2018) as host plants. The life cycle lasts two to three years. Pupation takes place in sapwood, in late May or June. Adults emerge in June-July and can be active to September; they are diurnal, the males are anthophilous. They feed mainly on the blossom of Apiaceae, Asteraceae, and Rosaceae.

Local occurrence and phenology. The species is widely distributed and quite abundant in the region. It is recorded from 52 districts (Fig. 6); the maximum of recorded adults was in July, the earliest record on 30 May, the latest on 7 September.

Comments. IUCN Red List Category (EU) - LC.

\section{S. (Maculileptura) maculicornis (DeGeer, 1775)}

Examined actual data. LT: Akm: Kamanu valstybinis gamtinis rezervatas, 24.0621.07.1980, 3, VM; ibidem, 28.06.1992, VM; Karniškių telmologinis draustinis, 29.07.1991, 2, VM; Purviai, 08.06.1993, 2, VM; Ramoniškè, 23.06.1993, 2, VM; Alyt: Vidzgirio botaninis draustinis, 05.06.1998, 2, RF; Punios šilas, 21.06.2017, 1, RF; Anyk: Ažuožeriai, 17.06.2020, in copula, 2 (Ф), RGa; Katlèrių miškas,
21.06.2018, 2 (Ф), AK; Traupis, 23-28.06.2020, 3 (Ф), SO; Drus: Viečiūnų miškas, 03.06.2019, VI; El: Alesninkai, 18.06.2017, 1 (Ф), AK; Baltamiškis, 20.06.2018, 1 (Ф), AK; Kazokiškès, 10.06.2017, 1 (ब), AK; Latviai, 09.07.2016, 1, VI; Paaliosė, 24.06.2020, 4 (D), JM; Panerių I miškas, 04.07.2020, 1 (Ф), JM; Ign: Ažvinčių gamtinis rezervatas, 19.06-25.07.2013, "window" trap, 3, VT; miškas Didžiagiris, 14.06.2016, 2, RF; Jona: Didysis Raistas, 17.06.2010, 1, VI; ibidem, 13.06.2016, 1, VI; Jonava, 18.06.1976, 1, col. unknown; Joni: Švètès slènio botaninis draustinis, 02.07.1992, 1, col.unknown; Jurb: Viešvilès valtybinis gamtinis rezervatas, 12.06.2008, 1, VT; K.R.: Jūrè, 25.06.1983, 2, RF; Jūrès miškas, 25.05.2000, 1, RF; Kazlų Rūda, 02.07.1968, 1, EG; ibidem, 22.07.1982, 1, RF; Kaiš: Būdos miškas, 15.06.2007, 1, VI; Grabuciškès, 08.06. 2019, 1 (D), JM; Kalvių miškas, 07.07.2001, 1, VI; Kruonis, 24.06.1996, 1, AM; Lapainia, 02.06.2007, 1, AM; Rumšiškių teriologinis draustinis, 08.06.2019, 1 (C), JM; Strošiūnų miškas, 10.06.2008, 2, VB; ibidem, 18.06.2009, 2, DSt; Kal: Juodeliai, 29.05.2002, 1, RF; Orija, 01.06.2020, 1 (Ф), VP; Kau: Akademija, 13.06.1995, 6, VT; Braziūkai, 10.06.2018, 1, ŽP; ibidem, 28-30.05.2019, 2, VT; ibidem, 19.06.2019, 1, VT; Dievogala (Palankiai), 01-11.04.1926, 3, PR; Dubravos miškas, 25.06.1956, 2, SP; ibidem, 23.06.1956, 1, SP; ibidem, 09.06.1968, 1, EG; ibidem, 19.06.1981, 1, RF; ibidem, 30.06.1984, 2, RF; ibidem, 09.06.1993, 1, RF; ibidem, 29.06.1999, 1, VT; Ežerèlis, 09.06.1985, 1, RF; Garliava, 12.06.2020, 1 (D), AKv; Jiesios kraštovaizdžio draustinis, 20.06.1983, 1, RF; ibidem, 03.06.2000, 1, RF; Kaunas, 24.05.1984, 1, RF; ibidem, 28.05.1986, 2, RF; ibidem, 06.06.2012, 1, RF; Kaunas (Dainava), 1 (Ф), JŽ; Kaunas (Kleboniškio miškas), 25.06.1956, 1, SP; ibidem, 24.07.2008, 1, VI; Kaunas (Naugardiškès), 13.05.2018, 1 (D), VBr; Kaunas (Panemunès šilo parkas), 05.06.2010, 1 (D), GS; Kaunas (Romainiai), 28.06.2006, 2, RF; Kačergine, 17.07.2017, 1, VI; Karmèlava, 04.06.2001, 4, VI; ibidem, 13.07.2001, 1, VI; ibidem, 20.06.2005, 1, VI; Laumenai, 28.06.2008, 4, VI; Margininkai, 10.06.1995, 1, VT; ibidem, 14.06.1999, 1, VT; Netoniai, 08-27.06.2017, 7, 
VI; Pilènų miškas, 05.06.2010, 1, VI; ibidem, 27.06.2010, 1, VI; 23.06.2016, 4, VI; Raudondvaris, 06.06.2001, 1, VI; Ringaudai, -.06.2004, 1, AJas; ibidem, 31.05.2012, 1, VT; Šlienava, 08.06.2020, in copula, 2 (D), obs. unknown; Turžènų miškas, 14.06.2010, 1, VI; Zapyškio miškas, 16.06.2019, 2, VT; Klai: Klaipèda, 25.06.2010, 1 (D), RGr; Kukuliškiai, 03.06.2019, 1 (Ф), PR; Melnragé, 08.07.1984, 5, SK; Kup: Drūlènų ežeras environs, 22.06.1994, 1, RPa; Laz: Avižieniai, 27.06.2020, 1 (ब), AB; Maž: Kiminiškè, 02.08.1991, 1, VM; Mol: Bendžiukai, 02.07.2020, 1 (Ф), EGr; Sližiškiai, 17.06.2018, 2 (C), GM; Ner: Juodkranté, 25.06.1988, 1, RF; ibidem, 20.06.1989, 1, RF; ibidem, 06.07.2005, 1, RF; Nida, 07.07.2017, in copula, 2 (6), GPe; Pal: Palanga, 14.07.2001, 1, VT; Pas: miškas Didieji Grūžiai, 22.06.2004, 2, VB; ibidem, 04.07.2005, 1, VB; Pumpènų miškas, 24.06.2006, 1, VB; Žadeikių miškas, 22.06.2005, 2, VB; Prie: Bačkininkų miškas, 01.07.1984, 1, RF; miškas Gojus, 30.06.2015, 1, RF; Jieznas, -.06.1962., 1, SP; Ras: Viduklè geležinkelio stotis, 17.06.1999, 3, VI; Šak: miškas Juškinè, 28.05-18.06.2000, 2, RF; ibidem, 21.06.2001, 1, RF; Tervydoniai, 20.06.2014, 1, RF; Šal: Gerviškiai (Dainava), 24.06.2020, 1 (D), AV; Stakai, 09.06.2019, 3, VT; Šiau: Einoraičiai, 15.07.1998, 1, RF; Paširvio miškas, 10.07.2020, 1, VT; Rekyvos miškas, 16.07.1998, 2, RF; Slydžiai, 03.06.2001, 1, VT; ibidem, 02.06.2019, 6, VT; Šila: Požerè, 30.06.1976, 1, VM; Šilu: Žalgirių miškas, 18.06.2002, 1, RF.; Širv: Kernave, 21.06.2020, 1 (D), LP; Šven: Antanų pedologinis draustinis, 21.06.2001, 1, RF; Antaviešè, 23.06.2018, 1 (Ф), GM; Bereišiūnų miškas, 08.07.2017, 1 (D), ŽP; Laukagalis, 16.06.2018, VI; Sariai, 30.06.2020, 1 (Ф), obs. unknown; Tau: Viešvilès valstybinis gamtinis rezervatas, 26.06.1991, 1, VM; ibidem, 11-12.06.1992, 7, VM; ibidem, 25.07.2000, 1, VU; Sakalynès miškas, 28.07.2008, 1, VT; Trak: Tamašava, 28.07.1997, 1, PI; Jogèlonių miškas, 26.07.2020, pheromone trap for Ips typographus, 3, DMa; Ukm: Jačionys, 06-26.06.1937, 6, PR; Ute: Minčios miškas, 29.05-19.06.2013, "window" trap, 2, VT; ibidem, 19.06-25.07.2013, 3, VT; Vilk: Grybingirio gamtinis rezervatas, 16.06.2016, 1,
RF; Vištytgirio botaninis-zoologinis draustinis, 31.05.2002, 1, RF; Viln: Elniakampio miškas, 18.08.2017, 1 (D), ŽP; Karmazinai, 27.06.2003, 1, RF; Maišiagala (Kalniškès), 08.05.2007, 1, PI; ibidem, 23.06.2007, 1, PI; Pavilnių regioninis parkas, 01.06.2018, 1 (D), TG; Vilnius (Baltupiai), 16.06.2018, 1 (Ф), AJu; ibidem, 03.06.2019, 1 (D), JM; Vilnius (Jaruzalè), 19.07.2018, 1 (C), JM; ibidem, 01.06.2018, 1 (Ф), GM; Vilnius (Lazdynai), 09.06.2020, 1 (Ф), PB; Vilnius (Verkių miškas), 02-06.06.2019, 2 (Ф), JM; ibidem, 15.06.2020, 1 (ு), GPe; Vilnius (Vingio parkas), 19.06.2003, 1, SS; Vilnius (Viršuliškès), 16.06.2020, 1 (Ф), MS; KR: Bagr: ZnamenkaNov., 12.06.1999, 1, VA; ibidem, 18.06.2000, 1, VA; $3 \mathrm{~km} \mathrm{~S} \mathrm{Novomoskovskoe,} \mathrm{08.06.2009,}$ 1, VA; ibidem, 01.06.2019, 1 (Ф), VA; Ladushkin, 08.06.2009, 1, VA; ibidem, 27.06.2010, 1, VA; ibidem, 25.06.2019, 1, VA; Ul'ianovka, 23.05.2018, 1 (D), VA; ibidem, 13.06.2020, 1 (D), VA; 2 km W Kamenka, 15.06.2019, 2 (D), VA; Cher: $4 \mathrm{~km}$ NE Cherniakhovsk, 24.05.1990, 1, VA; ibidem, 10.06.2020, 1 (D), VA; $7 \mathrm{~km}$ NE Cherniakhovsk, 19.06.2006, 2, VA; Pushkarevo, 26.06.2006, 2, VA; Gur: Kaliningrad, 09.06.2000, 1, VA; Pribrezhny, 01.06.2008, 1, VA; Gvar: 4 km S Ozerki, 02.06.2020, 2 (D), VA; Kras: Dolzhanskoe, 28.06.1997, 1, VA; Nest: Krasny Forest, 10.07.2001, 1, VA; 2 km NE Krasnoles'e, 08.06.2008, 1, VA; Pol: 3 km SE Veselovka, 09.06.1998, 2, VA; 1 km N Sosnovka, 22.06.2010, 1, VA; ibidem, 10.07.2011, 1 (Ф), VA; Prav: 2 km S Pravdinsk, 08.06.2019, 2, VA; Svet: Otradnoe, 29.06.2006, 1, VA; ibidem, 30.06.2010, 2, VA; ibidem, 28.06.2011, 1 (D), VA; Zel: Riabinovka, 22.05.2002, 1, VA; ibidem, 19.06.2002, 1, VA; ibidem, 20.06.2010, 1, VA; $3 \mathrm{~km}$ NE Zelenogradsk, 16.07.2015, 1, VA; Povarovka, 20.06.2019, 1, VA; Kostrovo, 18.06.2018, 1 (()), VA; ibidem, 09.06.2020, 1 (()), VA; Kremnevo, 12.07.2020,1 (C), VA.

Published local records. LT: This species is ranked as common and noted as distributed throughout the country by Pileckis, Monsevičius (1997 (Anoplodera). However, the actual faunistic information was given on occurrence of this species only in Lazdijai (Ostrauskas, Tamutis, 2012) and Elektrènai 
(Ostrauskas, 2020) (Paracorymbia) districts. This species was reported as common and numerous in the environs of Vilnius during the period of 1922-1937 by Zawadzki (1937) and Staniulisówna (1939) (Leptura). KR: Lentz, 1879 (Leptura); Bercio, Folwaczny, 1979 (Leptura); Alekseev, Sakhnov, 2002 (Anoplodera); Alekseev, 2006 (Paracorymbia); Alekseev, 2007.

General distribution. It is distributed from the mountainous regions of Iberia to the Urals (Chelyabinsk region). This species is widely distributed in northern Europe, while in southern Europe it occurs mainly in mountainous regions (Gobbi et al., 2012; Georgiev et al., 2015); it still has not been recorded in southern European Russia, southern Ukraine, and the Caucasus (Danievsky, 2014).

Notes on biology. This species seems to be polyphagous on various Pinaceae, Fagaceae, and Betulaceae, but prefers Pinus, Abies, and Picea. The larvae develop in dead decaying stems, stumps, or branches. The life cycle lasts two years. Pupation takes place in wood in spring. Adults emerge in May-June; they are diurnal and widely anthophilous.

Local occurrence and phenology. The species is widely distributed and quite abundant in the region. Recorded from 46 districts (Fig. 6); the maximum of recorded adults was in June, the earliest record on 8 May, the latest on 2 August.

Comments. IUCN Red List Category (EU) - LC.

\section{S. (Melanoleptura) scutellata scutellata}

\section{(Fabricius, 1781)}

Examined actual data. Absent. No material is available from LT and KR.

Published local records. LT: Tamutis et al., 2011, as expected; KR: Alekseev 2007, as improbable.

General distribution. The nominative subspecies is distributed in Europe from the Atlantic to the Balkan Peninsula, western Ukraine, Belarus, and Latvia. It is widely distributed in western and southern Europe; northwards, its distribution range reaches southern Scandinavia.
Notes on biology. The larvae develop in dead wood of various deciduous trees; most prefered hosts are Fagus, Quercus, Carpinus, Ulmus, Alnus, Corylus, and Fraxinus. The life cycle lasts three years; pupation takes place in wood, in early summer; adults emerge in JuneJuly; they are diurnal and anthophilous.

Local occurrence and phenology. Absent.

Comments. The species is recorded from all neighbouring countries, so its occurrence is possible in the region. IUCN Red List Category (EU) - LC.

\section{产 $S$. (Variileptura) variicornis variicornis} (Dalman, 1817)

Examined actual data. Absent. No material is available from LT and KR.

Published local records. LT: This species was ranked as very rare and noted as distributed in the eastern part of the country by Pileckis, Monsevičius (1997). KR: Lentz, 1879 (Leptura); Bercio, Folwaczny, 1979 (Leptura); Alekseev, 2007.

General distribution. It is distributed from eastern Europe to the Far East, Korea, and Japan. The western border of the distribution range is not clear; the westermost recent records are known from the western Latvia (Telnov et al., 2010), eastern Poland (Puszcza Białowieska) (Mapa Bioróżnorodności, 2020). Its northward distribution is also unclear, it is not included in the regional fauna of northeastern Russia (Tatarinova et al., 2016), although this region was included in the distribution range of the species by Plavilchikov (1936). The species is recorded in northern Ukraine (Bartenev, 2004) and Belarus (Solodovnikov, 2016).

Notes on biology. The larvae develop in the decaying wood of thick stems of both coniferous and deciduous trees, but coniferous trees are reported as more preferred in the western part of the species distribution range. The life cycle lasts three years. Pupation takes place in wood, in early summer. Adults emerge in mid summer; they are diurnal and anthophilous.

Local occurrence and phenology. Absent.

Comments. The first report of this species as a representative of the Lithuanian fauna was 
noted by Pileckis (1976) without actual faunistic data. This report was undoubtedly based on the data reported by Tenenbaum (1923: 171), who reported the presence of the specimens of this species from somewhere in the environs of Minsk (Pol., “...Widziałem również okazy $z$ Minska litewskiego...") or on the information from Zawadzki (1937), which reported this species in the environs of Navahrudak (Belarus) [Barowie, wojewódstwa Nowogrodskiego]. Still, there is a lack of any actual records of this species in the present territory of LT. The species was not found during our research in KR; however, it was noted in the territory [Bagr: Zinten; Nest: Rominten; Slav: Moosbruch] by Bercio, Folwaczny (1979). It is possibly an extinct species in the region; moreover, it is considered as very rare in the whole western part of its distribution range. IUCN Red List Category (EU) - EN.

\section{Genus Strangalia Audinet-Serville, 1835 S. attenuata (Linnaeus, 1758)}

Examined material. LT: $A \mathrm{~km}$ : Kamanų valstybinis gamtinis rezervatas, 21.07.1980, 1, VM; Rusteikiai, 23.07.1999, 1, RF; Alyt: Žuvinto biosferos rezervatas, 28.07.1973, 6, PI; Sabališkès pedologinis draustinis, 29.06.2020, 1, RF; Drus: Druskininkai, 12.06.1985, 2, EG; Gerdašiai, 13.07.1999, 1, RF; Latežeris, 13.06.1985, 2, EG; El: Lazdènai, 14.08.2017, 1 (Ф), AK; Paaliosè, 28.06.2017, 1 (Ф), AK; Pilypiškès, 14.08.2017, 1 (D), AK; Ign: Pakasas Lake environs, 16.07.1997, 1, VT; Jurb: Kaskalnio miškas, 10.06.1999, 1, VU; ibidem, 18.07.2000, 1, VU; ibidem, 24.07.2001, 1, RF; ibidem, 31.07.2008, 1, VT; Viešvilè, 17.07.1957, 1, SP; Kaiš: Kruonis, 15.07.1976, 1, AM; Strošiūnų miškas, 04.07.2009, 1, DSt; Kau: Braziūkų miškas, 19.06.2019, 1, VT; Dubravos miškas, 28.06.2981, 1, RF; ibidem, 06-23.07.1981, 3, RF; 22.06.1993, 1, RF; Karmèlava, 09.07.2011, 1, VI; Kaunas, 20.07.1973, 1, EG; Margininkai, 15.06.1995, 1, VT; Narèpai, 19.07.2005, 1, VT; Papiškinès miškas, 12.07.2019, 1, VT; Pilènų miškas, 26.07.2010, 1, VI; Raudondvaris, 16.06.1970, 1, EG; ibidem, 25.06.1975, 1, EG; Ringovès entomologinis draustinis, 31.07.2012, 1, RF; Kup: Palevenèlè, 02.07.1991, 1, RP; Laz: Prelomčiškè, 27.06.2018, 1, VI; Varnènai,
29.07.2018, 1, VI; Mol: Bendžiukai, 25.08.2020, 1 (Ф), EGr; Ner: Juodkrantè, 06.07.2018, 1 ('), RF; Pan: Geležiai, 12.07.1984, 1, SK; Pas: Rinkūnų miškas, 17.07.2006, 1, VB; Plu: Remtis Lake environs, 14.07.2020, 1 (D), RBu; Rok: Bagdoniškis, 14.06.2019, 1 (D), PA; Šak: Tervydoniai, 22.06.2013, 1, RF; ibidem, 17.06.2018, 1, RF; Šal: Raveliai, 15.08.2017, 1 (D), ŽP; Šiau: Einoraičiai, 15.07.1998, 2, RF; Šilu: Žemaičių Naumiestis, 01.08.2020, 1 (D), KK; Šven: Mekšrinis lake environs, 24.07.2009, 1 (Ф), AK; Pakretuonè, 17.06.2018, 1 (D), GM; Tau: Eičiai, 31.07.2017, 1 (D), RPa; Glitis lake environs, 11.07.2016, 1, VU; Jociai, 29.06.1993, 1, VU; Sakalynès miškas, 31.07.2009, 1 (D), GS; Viešvilès valstybinis gamtinis rezervatas, 19.07.2006, 1, RF; ibidem, 30.07.2008, 1, RF; Trak: Tolkiškès, 06.07.1978, 1, VUst; Ute: Butiškiai, 02.08.2020, 1 (D), KŠ; Var: Kimantiškès, 23.08.2016, 1, KM; Musteikos miškas, 04.07.2019, 1, RF; Puvočiai,15.08.1986, 1, VUst; ibidem, 25.08.2016, 1, KM; Spengla, 23.08.1991, 1, HO; Viečiūnai, 11.06.1985, 3, EG; Viečiūnų miškas, 10.07.2017, 2, VI; Viln: Bradeliškès, 30.06.2018, 1 (Ф), GM; Vilnius (Santariškès), 30.06.2018, 2 (D), AJu; Vilnius (Šeškinè), 01.07.2019, 1 (Ф), AJ; Vilnius (Žemasis Pavilnys), 11.07.2018, 1 (Ф), GPe; KR: Bagr: 2 km E Ladushkin, 19.07.2010, 1, VA; Ul'ianovka, 19.07.2010, 1 (Ф), VA; Cher: 1 km E Cherniakhovsk, 01.07.1993, 1, VA; 7 km NE Cherniakhovsk, 19.06.2006, 1, VA; ibidem, 27.07.2009, 1, VA; Pushkarevo, 26.06.2006, 1, VA; Gvar: 4 km S Ozerki, 18.06.2019, 1, VA; Svet: 1 km E Svetlogorsk, 07.08.2019, 1 (D), VA; Zel: 2 km NE Kostrovo, 30.06.2019, 1, VA; ibidem, 18.08.2020, 1 (Ф), VA.

Published local records. LT: This species is ranked as not common and noted as distributed throughout the country, except the Baltic Sea coast region, by Pileckis, Monsevičius (1997) (Strangalia, Strangalina). The actual faunistic information was given on occurrence of this species in Marijampole (Ferenca, 2006), Švenčionys (Ostrauskas, 2020), and Radviliškis Ostrauskas, Tamutis, 2012) districts. This species was reported as common in the environs of Vilnius during the period of 1922-1938 by Zawadzki (1937) (Typocerus). KR: Lentz, 1879; 
Bercio, Folwaczny, 1979; Alekseev, Sakhnov, 2002 (Strangalina); Alekseev, 2006, 2007.

General distribution. It is widely distributed throughout the Palearctic Eurasia from northern Spain to the Far East (Kamchatka, Sakhalin). The northern border of its distribution range reaches $60^{\circ} \mathrm{N}$ in Scandinavia, Finland, and Karelia and Kirov oblast (Russia). Southwards, it is known in Corsica (France), the Lazio region (Italy), Greece (Dascălu et al., 2012), Turkey, Iran, the northern provinces of China, Korea, and Japan.

Notes on biology. The species is polyphagous on deciduous trees. Quercus, Betula, Alnus, Corylus, Castanea, Ulmus, Tilia and Populus are regarded as the most prefered host plants. However, Cherepanov (1979) observed the larvae of this species in the stumps of Pinus. The larvae develop in decaying wood of stems and stumps over a period of at least of two years; pupation in wood. Adults appear in June or July; they are diurnal and anthophilous, feeding mostly on Apiaceae, Rosaceae, and Asteraceae.

Local occurrence and phenology. This species is widely distributed and common in the region. Recorded from 33 districts (Fig. 6); the maximum of recorded adults was in July, the earliest record on 10 June, the latest on 25 August.

Comments. IUCN Red List Category (EU) - LC.

\section{Tribe Oxymirini Danilevsky, 1997}

Genus Oxymirus Mulsant, 1858

1. O. cursor (Linnaeus, 1758)

Examined actual data. LT: Ign: Ažvinčių giria, 22.05-12.06.2020, "window" trap, 2, VT; Ignalina, -.06.1975, 1, SP; Vaišnoriškès, 06.06.1997, 1, RP; Zuikų miškas, 24.05.2020, 1 (Ф), GS; Joni: Nemeikšių miškas, 23.05.2002, 1, RB; ibidem, 01.07.2005, 1, RB; Tyrelio miškas, 20.06.2004, 1, RB; Jurb: Jurbarkas forest district, -.06.1953, 3, SP; Sakalinès miškas, 17.05.1994, 1, VU; Smalininkai, 07.05.2002, 1, VU; K.R.: Jūrès miškas, 29.04.1998, 1, RF; Kazlų Rūdos kraštovaizdžio draustinis, 28.05.2020, 1, VT; Kaiš: Strošiūnų miškas, 25.05.2008, 1, DSt; Vaiguvos miškas, 31.05.2009, 1, VB; Kau:
Braziūkai, 30.05.2012, 1, VT; Dubravos miškas, 09.01.2020, in decaying, moist wood of Pinus sylvestris, >10 larvae, VT; Ežerèlis, 21.06.2006, 1, AM; Kamšos miškas, 17.05.1996, 1, VT; ibidem, 12.04.2018, in decaying, moist wood of Salix caprea, 1 larva, VT; Karmèlavos miškas, 02.05.2006, 2, VI; Ner: Juodkrantè, 31.05.2011, 1, RPa; ibidem, 01.06.2011, 1, RF; Pas: Rinkūnai, 18.05.2006, 1, VB; Ramoninè, 16.06.2006, 1, VB; Plu: Plokštinès miškas, 26.05.2012, 1, RF; Šeirès miškas, 22.05.2011, 1, GS; Širv: Draučių miškas, 11.05.2018, 1 (6), AJu; Tau: Viešvilès valstybinis gamtinis rezervatas, 25.05.2005, 1, VU; Ukm: Kazlaučizna (Kalnų miškas), 30.05.2020, 1 (Ф), obs. unknown; Tel: Gadūnavas, 16.07.1995, 1, A. Buiškys; Viln: Šilènų miškas, 30.05.2020, 1 (C), VTv; Zar: Zarasai, -.07.1960, 1. SP; KR: Bagr: Ladygino, 24.05.2016, 1, VA; Svet: 3 km W Svetlogorsk, 03.05-13.06.2019, pitfall trap near pine log, 1, VA; Zel: Kolosovka, 12.05.1996, 1, MT; 4 km NE Zelenogradsk, 21.05-13.06.2012 pitfall traps near fir log, 2, VA.

Published local records. LT: This species is ranked as not rare and noted as being distributed throughout the country by Pileckis, Monsevičius (1997). The actual faunistic information on the occurrence of this species is given in Alytus (Pileckis, 1958 (Toxotus); Ferenca, 2006), Kaunas (Inokaitis, 2004), Vilnius, and Šalčininkai (Staniulisówna, 1939; Ivinskis et al., 2009) districts. KR: Lentz, 1879 (Toxotus cursor L., noctis L.); Bercio, Folwaczny, 1979 (Toxotus); Alekseev, 2007; Alekseev, Bukejs, 2014, 2017.

General distribution. It is distributed from the northern part of Iberia to the Altai, Tomsk region. The northern border of the distribution range goes to $67^{\circ} \mathrm{N}$ in Scandinavia and $63^{\circ} \mathrm{N}$ in European Russia. It occurs mainly in the mountainous regions of central and southern parts of Europe (Zandigiacomo, Cogoi, 2000; Mpamnaras, Eliopoulos, 2017). The occurrence of this species in Turkey (Turgut et al., 2010) and China (Gessit, 1951) was doubted by Danilevsky (2014).

Notes on biology. This species is polyphagous but prefers coniferous trees such as Picea, Pinus, Larix, and Abies. Rarely, it also inhabits Fagus, Alnus, Betula, Quercus, and Corylus. 
Larvae develop in dead decaying moist wood over a period of three years. Last instar larvae leave wood, overwinter in the soil, and then pupate in spring. The adults emerge in late April and May; they are predominantly active at night, usually crawling on the ground or on stumps, very occasionally on blossom.

Local occurrence and phenology. This species is locally distributed in the region but seems to be uncommon due to the cryptic lifestyle of adults. Recorded from 22 districts (Fig. 7); the maximum of recorded adults was in May, the earliest record on 29 April, the latest on 17 July.

Comments. IUCN Red List Category (EU) - LC.
Tribe Rhagiini Kirby, 1837

\section{Genus Brachyta Fairmaire, 1864}

st, 1784)

产 $B$. (s. str.) interrogationis russica (Herb-

Examined actual data. Absent. No material is available from LT and KR.

Published local records. LT: The actual faunistic information on the occurrence of this species (Evodinus interrogationis) in Lithuania is given by Pileckis, Monsevičius (1997: 95), with an explanation that one specimen is deposited in Vilnius University with label data "1892 Medyna B. H." (Bronislaw Houwald) and two specimens were collected by Simonas Pileckis in Obelyne near Kaunas on 01 July 1987. KR: Alekseev, 2007, as improbable.

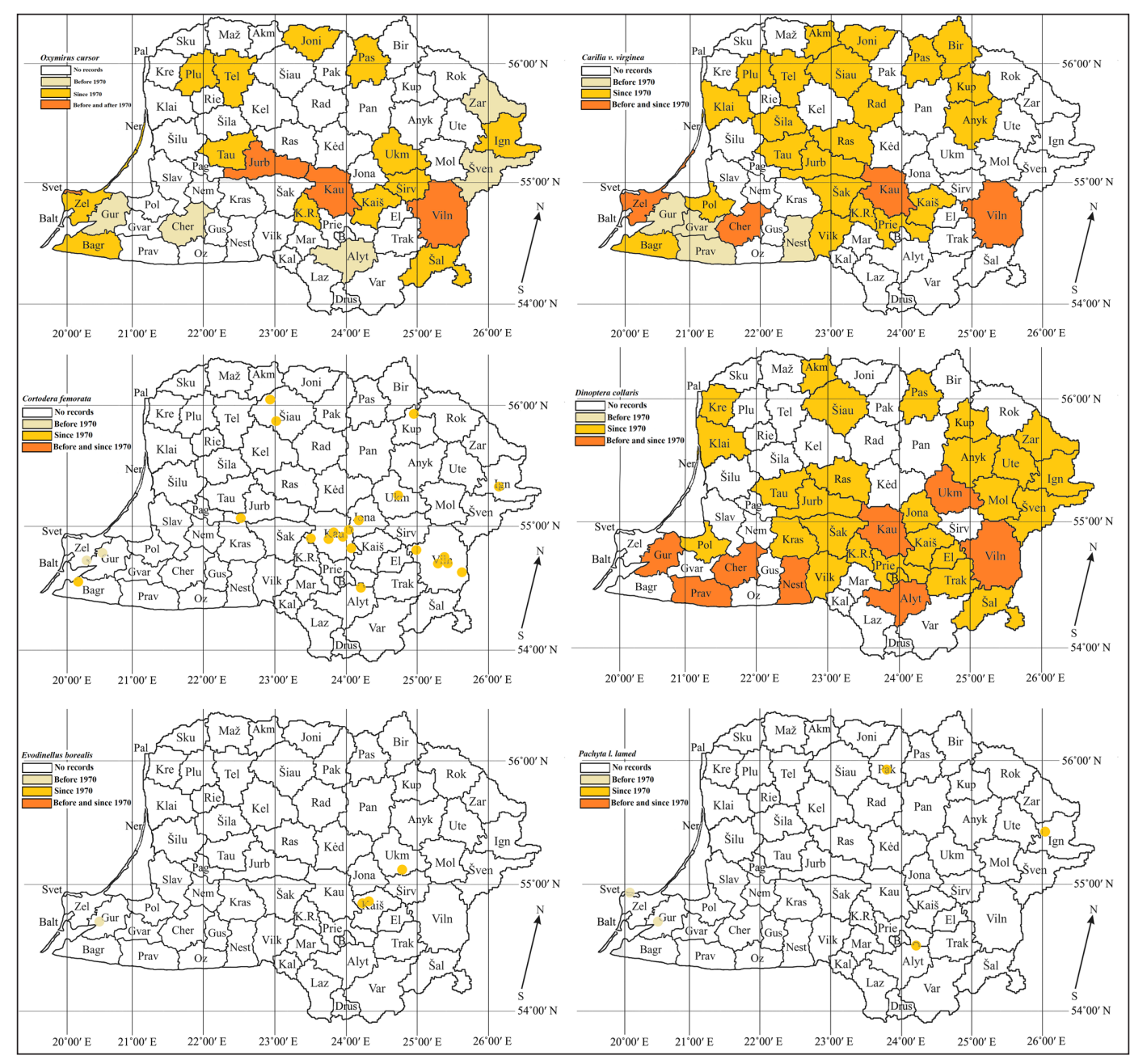

Fig. 7. Maps of distribution of Oxymirus cursor, Carilia v. virginea, Cortodera femorata, Dinoptera collaris, Evodinellus borealis, and Pachyta l. lamed (Coleoptera: Cerambycidae: Lepturinae) in the south-eastern Baltic region 
General distribution. It is distributed from the French Alps to the Far East. The northern border of its distribution range reaches the Northern provinces of Fennoscandia (Lapponia inarensis) and north-eastern European Russia (Vorkuta) (Tatarinova et al., 2016). The species is rare and sporadic in southern Europe, occurring mainly in mountainous areas (Kierdorf-Traut, 2007; Danilevsky, Peks, 2016). Currently, 12 subspecies are known and only B. interogationis russica (Herbst, 1784) is noted from the Baltic countries and the central part of European Russia (Lazarev, 2016; Danilevsky, 2019).

Notes on biology. The species is largely polyphagous on various herbs, but seems to prefer particular plants depending on its geographic distribution. The larvae of this species were found mostly bored in roots of Paeonia anomala, but occasionally also in Euphorbia pilosa, Trollius asiaticus, and Rhodiola rosea in Siberia (Cherepanov, 1979); in Europe, however, they were observed in the roots of Geranium sylvaticum (Vincent, Guillot, 1983; Švácha, 1989; Heyrovský, Sláma, 1992). Pupation takes place in autumn or spring in the soil, near the host roots. Adults emerge in May; they are diurnal and anthophilous, usually visiting the blossom of host plants.

Local occurrence and phenology. No actual information in the region.

Comments. We doubt the occurrence of B. interrogationis in LT, because previous published records lack voucher specimens. All available examined specimens of Brachyta (Evodinus) were from the collections of Vilnius University and Kaunas Tadas Ivanauskas Zoological Museum, where the material collected by Houwald and Pileckis is currently deposited. We found only one specimen of Brachyta sp. (Evodinus) labeled "Evodinus, Mikolajevsk Amur, 1911, BH" by Houwald in the collections of Vilnius University. It means that this specimen was collected in the Amur region (Siberia, Russia). Unfortunately, we did not find any specimen of related taxa in the material collected by Pileckis. The species has not been reported for 230 years and was considered extinct in the territory of KR (Alekseev, 2007). How- ever, Lentz (1879) originally wrote as a note for this species: "in Kiefernwälder auf Farnkraut gefunden" [found in conifer forests on ferns]. Bercio, Folwaczny (1979) added no new information later, but simply cited the name of the species, the year, and the locality. It is very probable that there was confusion about these two comparatively similarly coloured but different species of host plants (Brachyta interrogationis and Evodinellus borealis). Therefore, the old data for "Pachyta interrogationis" should really refer to E. borealis. Most recent neighbour records of this species are known from Latvia (Telnov et al., 2008, 2016), so the occurrence of this species in the region is possible.

\section{Genus Carilia Mulsant, 1863}

C. virginea virginea (Linnaeus, 1758)

Examined material. LT: $A \mathrm{~km}$ : Kamanų valstybinis gamtinis rezervatas, 03-21.07.1980, 8, VM; Pragalvojai, 21.09.2009, 1 ('), NV; Anyk: Traupis, 23.06.2020, 1 (()), SO; Bir: Spalviškiai, 02.06.1999, 1, PI; Joni: Bariūnai, 16.05.2004, 1, RB; Juodeikai, 24.06.2005, 1, RB; Plikiškiai, 08.06.2009, 1, RB; Satkūnai, 04.06.1999, 2, RB; ibidem, 23.06.2006, 1, RB; Jurb: Viešvilès valstybinis gamtinis rezervatas, 15.06.1994, 1, VU; ibidem, 22.06.1999, 2, VU; K.R.: Braziūkų miškas, 20.06.2017, 1, VT; Jūré, 17.06.1984, 1, RF; ibidem, 25.05.2000, 1, RF; Kazlų Rūda, 21.05.1989, 1, AM; Skriaudžių miškas, 14.06.2020, 1 (D), VGl; Kaiš: Pravieniškès, 13.06.2006, 1, AM; Strošiūnu miškas, 15.06.2008, 1, DSt; Kau: Braziūkai, 26.05.2014, 1, VT; ibidem, 28.05.2020, 1, VT; ibidem, 10.06.2020, on blossom of Prunus serotina; 1, VT; Dubravos miškas, 11.06.1956, 1, SP; ibidem, 17.06.1978, 1, RF; ibidem, 07.06.1981, 1, RF; ibidem, 28.06.1981, 4, RF; ibidem, 06.07.1985, 1, RF; ibidem, 22.06.1993, 1, RF; ibidem, 02.06.2020, 1 (Ф), RF; Kamšos miškas, 14.07.1996, 1, VT; Karmèlavos miškas, 25.05.2008, 2, VI; Kaunas (Šančiai), 25.06.2012, 1, RF; Klai: Pèžaičiai, 31.05.1989, 4, SK; Šernai, 17.06.1989, 2, SK; Kup: Mirabelio miškas, 22.06.1991, 1, RP; Pas: Krikliniai, 12.06.2007, 1, VB; miškas Didieji Grūžiai, 06.06.2007, 1, VB; Rinkūnų miškas, 04-12.06.2005, 2, VB; Plu: 
Plokštinès miškas, 21.06.2020, > 10 on blossom of Apiacea, VT; Prie: Bačkininkų miškas, 23.06.1984, 1, RF; Rad: Praviršulio tyrelio botaninis-zoologinis draustinis, 16.06.2009, 1, SR; Ras: Lyduvenai, 26.05.2018, 2, VT; Sargeliai, 1 (D), GS; Šak: miškas Juškinè, 01.06.2003, 1, RF; Šiau: Paširvio miškas, 10.07.2020, "window trap”, 1, VT; Šila: Juodžiai, 24.06.2012, 1 (C), RF; Tau: Viešvilès valstybinis gamtinis rezervatas, 08.07.2008; 1, RF; Tel: Kegai, 01.07.1985, 1, VUst; Vilk: miškas Vištytgiris, 31.05.2002, 1, RF; Viln: Bieliūnai, 06.06.2020, 1 (()), APe; Elniakampio miškas, 18.05.2018, 1 (Ф), GM; Suderve, 30.05.2020, 1 (D), obs. unknown; KR: Bagr: 1 km E Ladushkin, 04.06.2014, 1 (Ф), VA; Ladygino, 24.05.2016, 1 (D), VA; 3 km W Kamenka, 15.06.2019, 1 (D), VA; Cher: 1 km NW Cherniakhovsk, 12.06.1993, 1, VA; 7 km NE Cherniakhovsk, 24.06.2006, 1, VA; ibidem, 20.06.2005, 1, VA; Pushkarevo, 26.06.2006, 1, VA; Pol: $3 \mathrm{~km}$ SE Veselovka, 09.06.1998, 1, VA; Sosnovka, 22.06.2010, 1, VA; ibidem, 12.06.2019, 1, VA; Svet: 3 km W Svetlogorsk, 26.05.2014, 1, VA; Otradnoe, 29.06.2006, 1, VA; Zel: 3 km NE Zelenogradsk, 13.06.2009, 1, VA; Riabinovka, 20.06.2010, 1, VA; 3 km NE Kostrovo, 18.06.2018, 1 (Ф), VA.

Published local records. LT: This species is ranked as rare and noted as distributed throughout the country, excluding the coast and south-western regions of the Baltic Sea by Pileckis, Monsevičius (1997) (Gaurotes). The actual faunistic information was given on the occurrence of this species (Gaurotes) in Vilnius (Zawadzki, 1937) and Kaunas (Pileckis, Monsevičius, 1997) districts. KR: Lentz, 1879 (Pachyta); Bercio, Folwaczny, 1979 (Gaurotes); Alekseev, Sakhnov, 2002 (Gaurotes); Alekseev, 2006, 2007.

General distribution. It is distributed from the French Alps and Scandinavia to the Far East, Korea, and Sakhalin. The northern border of the distribution range goes to $68^{\circ} \mathrm{N}$ in Scandinavia and $63^{\circ} \mathrm{N}$ in European Russia. The southernmost records of this species are known from northern Spain, Italy, and Greece. Nominative subspecies is known in Europe and West Siberia.
Notes on biology. The larvae of this species develop under the bark of stumps, stems, and branches of dead coniferous trees. The Picea is considered as the main host plant in Europe (Starzyk, 1977), while Pinus, Larix, and Abies also are regarded as suitable for the development of this species in Siberia (Cherepanov, 1979). Mature larvae usually leave the host for a second hibernation in the soil and pupate there in spring; occasionally, they pupate under bark (Starzyk, 1977). The life cycle lasts two years (Starzyk, 1977; Cherepanov, 1979). Adults appear mainly from middle May and June; they are diurnal and widely anthophilous.

Local occurrence and phenology. The species is widely distributed and common in the region. Recorded from 30 districts (Fig. 7); the maximum of observed adults was in June, the earliest observation on 16 of May, the latest on 21 July.

Comments. IUCN Red List Category (EU) - LC.

\section{Genus Cortodera Mulsant, 1863}

C. femorata (Fabricius, 1787)

Examined actual data. LT: Alyt: Punios šilas, 09.06.2020, 1, RF; Ign: Papiliakalnès miškas, 18.05.2019, 1, (C), GPe; Jona: Melnytèlè, 10.05.2019, 1 (Ф), JZ; Jurb: Viešvilè, 23.05.1994, 1, VU; Kau: Braziūkai, 30.05.2019, 1, on blossom of Apiacea, VT; Braziūkų miškas, 16.05.2020, 1, VT; Dubravos miškas, 12.06.1957, 1, SP, ibidem, 07.06.1958, 1, SP; ibidem, 02.06.2020, 1 (D), RF; Karmèlavos miškas, 29-30.05.2004, 2, VI; Kaunas (Dainava), 10.06.2017, 1, VI; Kaunas (Kleboniškio miškas), 01.05.2002, 1, VI; Kaunas (Panemunès šilas), 27.05.1997, 1, AM; Ringaudai, 15.06.2005, 1, AJas; Šlienava, 04.05.2001, 1, VI; Turžènų miškas, 11.06.2010, 1, VI; Kup: Užubaliai, 19.05.1995, 2, RP; ibidem, 13.06.1995, 3, RP; Šiau: Bacaičiai, 04.06.1974, 1, VM; Paraudžių miškas, 22.04.2004, 1, GR; Viln: Aukštagiris, 05.06.2016, 1 (D), ŽP; Dūkštu miškas, 10.05.2019, 1 (Ф), AJu; Pylimai, 23.05.2020, 1 (()), GM; Varniškès, 15.05.2020, 1 (C), JM; Vilnius (Š́eškinè), 09.05.2020, 1 (()), JM; Vilnius (Verkių miškas), 18.05.1773, 1, VKa; KR: Bagr: Ul'ianovka, 13.06.2020, 1, VA. 
Published local records. LT: The species was ranked as very rare and noted as distributed in the central region by Pileckis, Monsevicius (1997). The actual faunistic information was given on the occurrence of this species in Ignalina (Šablevičius, 2003, 2004), Kaunas (Pileckis, 1960; Inokaitis, 2004, 2009), Šiauliai (Pileckis, Monsevičius, 1997), Ukmergè (Stanionis, Petrikas, 2011), and Vilnius (Ostrauskas, 2000; Butvila et al., 2007) districts. KR: Lentz, 1879 (Grammoptera 4-guttata var. femorata); Bercio, Folwaczny, 1979; Alekseev, Sakhnov, 2002; Alekseev, 2007; Alekseev, Bukejs, 2011.

General distribution. It is distributed from the French Alps and Scandinavia to West Siberia. The northern border of the distribution range goes to $63^{\circ} \mathrm{N}$ in Finland and $60^{\circ} \mathrm{N}$ in European Russia. This species is sporadically distributed in southern Europe.

Notes on biology. Little is still known about life history of this species. Presumably, the larvae develop in decaying wood debris of coniferous trees in the upper layer of forest litter; occasionally, some larvae were found in the fallen cones of Norway spruce in Sweden. The life cycle lasts two years. Adults appear mainly in May and June; they are diurnal and anthophilous.

Local occurrence and phenology. This species is locally distributed and rare in the region. Recorded from 12 districts (Fig. 7); the maximum of observed adults was in May, the earliest observation on 22 April, the latest on 19 June.

Comments. Earlier reports (Alekseev, Sakhnov, 2002; Alekseev, 2007; Alekseev, Bukejs, 2011) from KR resulted from misidentifications.

\section{Genus Dinoptera Mulsant, 1863 \\ D. collaris (Linnaeus, 1758)}

Examined actual data. LT: Akm: Maigu miškas, 09.06.2020, 1 (Ф), SSo; Kamanų valstybinis gamtinis rezervatas, 05.07.2003, 1, VM; Alyt: Obelija, 07-25.07.1980, 2, VUst; Punios šilas, 27.06.2008, 2, RF; ibidem, 21.06.2017, 1, RF; Sabališkių miškas, 09.06.2020, 1, RF; Vidzgirio botaninis draustinis, 05.06.1998, 1, RF; Žuvinto gamtinis rezervatas, 31.05.1925, 1, AP; Anyk: Traupis, 1 (Ф), SO; B: Nemajūnų šilas, 20.06.2009, 1 (6), GS; Ign: Ažvinčių gamtinis rezervatas, 19.06-27.07. 2013, "window" trap, 1, VT; Jona: Didysis Raistas, 10.06.2010, 3, VI; Joni: Satkūnai, 21.06.1998, 2, RB; Skilvioniai, 06.09.2004, 1, RB, ibidem, 29.06.2005, 1, RB; Jurb: Viešvilès valstybinis gamtinis rezervatas, 22.06.1999, 1, VU; ibidem, 13.06.2007; 1, RF; ibidem, 12.06.2008, 8, VT; K.R.: Jūrès miškas, 25.05.2000, 1, RF; Kaiš: Būdos miškas, 18.06.2020, 5, VT; Grabuciškès, 08.06.2019, 1 (Ф), JM; Kruonis, 28.06.1976, 1, AM; Kruonio miškas, 13.06.2008, 1, VB; Vaiguvos miškas, 02.06.2007, 2, VI; Strošiūnų miškas, 18.06.2009, 1, DSt; ibidem, 03.07.2009, 2, DSt; Kau: Braziūkai, 10.06.2006,1, VT;ibidem, 10.07.2019, 1, VT; Dubravos miškas, 22.06.1983, 1, RF; Ežerèlis, 12.07.1927, 1, AP; ibidem, 28.IV.1928, 1, AP; Girionys, 09.07.1972, 1, EG; Jiesios kraštovaizdžio draustinis, 31.05.1981, 2, RF; ibidem, 13.06.1981, 2, RF; ibidem, 25.05.1984, 1, RF; ibidem, 28.05.1998, 1, RF; 07.06.2000, 1, RF; Karmèlavos miškas, 05.06.2005, 2, VI; ibidem, 05.06.2008, 1, VI; ibidem, 08.06.2012, 1, VI; Kaunas, 05.09.1932, 1, PRè; ibidem, 01.05.1937, 1, AP; ibidem, 27.05.1986, 1, RF; Kaunas (Freda), 03.06.1981, 1, RF; Kaunas (Kleboniškio miškas), 17.06.2002, 1, VI; Kaunas (Romainiai), 19.06.2008, 1, RF; Netoniai, 08.06.2017, 1, VI; Patamulšèlis, 08.07.2017, 1, VI; Raudondvaris, 02.06.2001, 2, VI; Ringovès entomologinis draustinis, 04.07.1996, 1, RF; Klai: Lapiai, 11.06.1983, 1, SK; Kret: Kulūpènai, 13.06.1989, 5, SK; Kup: Mirabelio giria, 22.06.1991, 1, RP; Mol: Molètai, 31.05-03.06.1973, 1, EG; Pas: Pumpènai, 24.06.2006, 1, VB; Putriškio miškas, 16.06.2004, 2, VB; Rinkūnų miškas, 12.06.2005, 2, VB; Prie: Balbieriškio miškas, 09.06.2020, 1, VT; miškas Gojus, 18.06.2020, 5, VT; Ras: Lyduvėnai, 26.05.2018, 2, VT; Numigaliai, 16.06.2020, 1 (D), JM; Šak: miškas Juškinè, 10.06.2000, 2, RF; ibidem, 30.05.2014, 1, RF; Šal: Visinčios hidrografinis draustinis, 20.06.1985, 1, RF; Šiau: Slydžiai, 20.06.2020, 2, VT; Paširvio miškas, 01-20.06.2020, "window" trap, 2, VT; Šven: Modžiūnai, 19.06.2020, 2 (D), ŽO; Tau: Buveiniai, 27.06.2001, 1, VU; Eičiai, 15.06.2007, 1, RF; Glitis lake environs, 13.06.2008, 2, VT; Paikojai, 22.06.1999, 1, 
VU; Viešvilès valstybinis gamtinis rezervatas, 15.06.2000, 1, VU; ibidem, 25.07.25, 1, VU; Trak: Čižiūnai, 06.06.2001, 1, PI; Mergiškių miškas, 18.06.2020, >10, on blooms of Apiacea, VT; Moša, 29.06.1994, 1, PI; Tolkiškès, 0305.07.1978, 3, VUst; Ukm: Jačionys, 29.06.1937, 1, PRé; Felinkos miškas, 06.06.2015, 1, RF; Ute: Kvykliai, 24.06.2018, 1 (D), ŽP; Vilk: miškas Vištytgiris, 31.05.2002, 1, RF; Viln: Elniakampio miškas, 18.06.2017, 1 (C), DB; Karmazinai, 27.05.2018, 1 (), AJu; Maišiagala (Kalniškès), 23.06-07.07.2008, Malaise trap, 2, PI; Paberžè (Medyna), 10.06.1914, BH; Pavilnių regioninis parkas, 12.06.2017, 1 (ब), AK; Vilnius (Antakalnis), 01.06.2018, 1 (), GM; Vilnius (Jaruzalè), 22.05.2018, 1 (), GM; Zar: Dusetos, 17.07.1979, 1, VUst; KR: Cher: 7 km NE Cherniakhovsk, 19.06.2006, 1, VA; Gur:1 km W Kaliningrad, 14.06.2020, 1 (D), VA; Kras: Dolzhanskoe, 27.06 1997, 1, VA; ibidem, 02.06.2002, 1, VA; Nest: 2 km NE Krasnoles'e, 08.06.2008, 2, VA; Pol: $2 \mathrm{~km}$ N Bogatovo, 22.06.2010, 3, VA; Fevral'skoe, 28.06.2020, 2 (D), VA; Prav: 1 km S Pravdinsk, 08.06.2019, 1, VA.

Published local records. LT: This species was ranked as common and noted as distributed in the central and south-western regions by Pileckis, Monsevičius (1997) (Acmaeops). The actual faunistic information was given on the occurrence of this species (Acmaeops) in Vilnius (Zawadzki, 1937; Ostrauskas, 2020), Kaunas (Pileckis, 1963), Alytus (Ferenca, 2006), and Elektrènai (Ostrauskas, 2020) districts. KR: Lentz, 1879 (Pachyta); Bercio, Folwaczny, 1979 (Acmaeops); Alekseev, Sakhnov, 2002 (Acmaeops); Alekseev, 2006, 2007.

General distribution. It is distributed from Iberia and Great Britain to the Altai region. The northern border of its distribution range reaches $60^{\circ} \mathrm{N}$ in Scandinavia and goes throughout St Petersburg, Perm and Kirov regions in European Russia. The species is widely distributed in southern Europe and is also known in the Caucasus, Turkey, and Iran.

Notes on biology. The larvae of this species develop mainly in dead branches, open roots, or thin stems of various deciduous trees over a period of two years. Mature larvae leave the host plant and overwinter in forest litter. Pupation takes place in spring. Adults emerge mainly in the June; they are diurnal and widely anthophilous.

Local occurrence and phenology. This species is widely distributed and common in the region; recorded from 35 districts (Fig. 7); the maximum of observed adults was in June, the earliest observation on 28 April, the latest on 05 September.

Comments. IUCN Red List Category (EU) - LC.

\section{Genus Euracmaeops Danilevsky, 2014}

旁 E. angusticollis (Gebler, 1833)

Examined actual data. Absent. No material is available from LT and KR.

Published local records. LT: Tamutis et al., 2011, as expected.

General distribution. The species is widely distributed in Siberia, with just several records known from eastern Europe, of which the westernmost are still from western Belarus (Kazyuchits, Pisanenko, 1985) and eastern Poland (Gutowski, 1995).

Notes on biology. The larvae develop under the bark of stems and branches of dead Pinus sibirica (Cherepanov, 1979), rarely of Picea abies or Pinus sylvestris. Pupation takes place under bark in May-June. Adults emerge in June-July; they are diurnal and anthophilous. The life cycle lasts two years.

Local occurrence and phenology. Absent.

Comments. The species was relatively recently found in Puszcza Białowieska (Mapa Bioróżnorodności, 2020) and is known in some neighbouring districts of Belarus (Kazyuchits, Pisanenko 1985), so its presence in eastern and southern parts of LT is quite possible. IUCN Red List Category (EU) - CR.

\section{旁 E. marginatus (Fabricius, 1781)}

Examined actual data. Absent. No material is available from LT and KR.

Published local records. LT: The actual faunistic information is given by Pileckis, Monsevičius (1997:96) (Acmaeops marginata) based on old records from the environs of 
Vilnius (Staniulisówna, 1939); also noted for Klaipeda [Memel] district by Bercio, Folwaczny (1979). KR: Alekseev, 2007 (Acmaeops).

General distribution. It is distributed from Iberian and Scandinavian peninsulas to the Far East, Kamchatka, and Sakhalin. The northern border of its distribution range goes to $67^{\circ} \mathrm{N}$ in Scandinavia, and $63^{\circ} \mathrm{N}$ in European Russia. The southernmost records of this species are known from northern Spain, Italy, Montenegro, Greece, and Turkey.

Notes on biology. The larvae develop mainly in dead stems or branches of coniferous trees, but they prefer pines. Mature larvae leave the host plant and overwinter in the litter. Pupation takes place in spring. Adults emerge mainly in June; they are diurnal and anthophilous. The life cycle lasts two years. Some authors regarded this species as fire-adapted or pyrophilous (Burakowski et al., 1990; Wikars, 1997; Miłkowski, 2004; Süda et al., 2009) and preferring mature stands (Gorski, Tatur-Ditkowski, 2015; Ruchin, Egorov, 2018).

Local occurrence and phenology. No actual information in the region.

Comments. We cannot confirm the occurrence of E. marginatus in LT, because the previous published records lack voucher specimens. This species is not formally known in the territory of KR from the literature. All above-listed references "for KR" contain data of the species in northern Poland or Lithuania. The most recent and nearby records of this species are known from north-eastern Poland (Miłkowski, 2004; Gorski, Tatur-Ditkowski, 2015), so we expect this species to occur in the region. IUCN Red List Category (EU) - VU.

\section{旁 E. septentrionis (Thomson, 1866)}

Examined actual data. Absent. No material is available from LT and KR.

Published local records. LT: No actual published records, but it was listed in some catalogues (Danilevsky, Smetana, 2010; Danilevsky, 2019). KR: Alekseev, 2007 (Acmaeops) as improbable.

General distribution. It is distributed from Scandinavia to the Far East, Kamchatka, Korea,
Sakhalin, and Hokkaido. This species is widely distributed in northern Europe and the mountainous areas of central Europe. However, the discoveries of this species in lowland forests by Gorski, Tatur-Ditkowski (2015) suggest a wider ecological range of the species.

Notes on biology. The larvae of this species develop under the loose bark of stems of dead coniferous trees, with preference for spruce. Mature larvae leave the host plant and overwinter in the litter, rarely finishing its development under the bark of the host tree. Pupation takes place in spring. Adults emerge mainly in June; they are diurnal and anthophilous. The life cycle lasts two years. Some authors regarded this species as fire-adapted or pyrophilous (Wikars, 1997; Süda et al., 2009).

Local occurrence and phenology. No actual information in the region.

Comments. We cannot confirm the occurrence of E. septentrionis in the region due to the lack of voucher material. However, assuming the recent discoveries of the species in lowland forests in Poland (Plewa, 2010; Gorski, Tatur-Ditkowski, 2015; Wiśniowski, Baran, 2016), we expect the occurrence of this species in the region. IUCN Red List Category (EU) - LC.

\section{E. smaragdulus (Fabricius, 1792)}

Examined actual data. Absent. No material is available from LT and KR.

Published local records. LT: The actual faunistic information is given on the occurrence of this species (Acmaeops smaragdula) only in the Vilnius district by Zawadzki (1937); it was also noted for LT (Litwa) without actual data by Kinel (1917). KR: Alekseev, 2007 (Acmaeops), as improbable.

General distribution. It is distributed from Scandinavia to the Far East, Kamchatka, Korea, and Sakhalin, and is also known in northern Mongolia and China. This species is widely distributed in northern Europe, while in the central part it is recorded only from the French Alps (Villiers, 1978), Lithuania (Zawadzki, 1937), and Belarus (Aleksandrowicz et al., 1996).

Notes on biology. The larvae of this species develop in dead stems of coniferous trees; 
in Siberia, it mainly inhabits Pinus and Abies. The life cycle is similar to E. septentrionis.

Local occurrence and phenology. This species was found in a single district in LT (Zawadzki, 1937). Altogether, five specimens were observed from 3 to14 June.

Comments. Zawadzki (1937) noted that five individuals of the species were collected in the environs of Vilnius in June 1923-1928; three of them were re-examined by Gutowski and Sláma, who confirmed them to be Euracmaeops smaragdulus (Acmaeops) (Gutowski, 1988). Currently, these specimens are deposited at the Museum of the Institute of Zoology of the Polish Academy of Sciences (R. Plewa personal communication). IUCN Red List Category (EU) - EN.

\section{Genus Evodinellus Plavilstshikov, 1915}

E. (s. str.) borealis (Gyllenhal, 1827)

Examined actual material. LT: Kaǐ̌: Palaraisčio telmologinis draustinis, 05.05.2016, 1, KM (KZM); Pravieniškès, 09.05.1986, 1, RF (KZM); Ukm: Kertušas lake strand, 1118.05.1997, automatic light trap, 2, GŠ (KZM); ibidem, 28.05-04.06.1997, automatic light trap, 1, GŠ (KZM); KR: no actual data.

Published local records. LT: The actual faunistic information is given on the occurrence of the species (as Evodinus borealis) from Kaišiadorys (Pileckis, Monsevičius, 1997) and Ukmergè (Ferenca, 2003) districts. KR: Lentz, 1879 (as Pachyta interrogationis); Bercio, Folwaczny, 1979 (cited Evodinus interrogationis); Alekseev, 2007.

General distribution. It is distributed from Scandinavia to the Far East, Mongolia, northeastern China, Korea, and Honshu Island. The northern border of its distribution range reaches the northern provinces of Fennoscandia (Lapponia inarensis) and north-eastern European Russia. However, it is rarely observed in the whole range; it is especially rare in central Europe (Gutowski, Karaš, 1991; Sláma, 1998; Jendek, Jendek, 2006; Eckelt et al., 2018).

Notes on biology. The larvae of this species develop in dying or freshly dead (cut) branches or thin stems of coniferous trees. In Poland, they were found in the branches (3-4 cm in diameter) of fallen Picea abies (Gutowski, Karaš, 1991). Pupation usually takes place in the soil near the host plant. Adults emerge in May-June; they are diurnal and anthophilous, feeding on the blossom of Anemone nemorosa, Oxalis acetosella, Chaerophyllum hirsutum, Sorbus aucuparia, Viburnum opulus, Rubus saxatilis, Anthriscus sylvestris, and Angelica sylvestris. The life cycle lasts two years. It is worth noting that some specimens of our examined material were caught using light traps.

Local occurrence and phenology. This species is locally distributed and rare in the region; found in two districts (Fig. 7); recent records from KR are lacking.

Comments. The occurrence of this species in LT is confirmed by voucher specimens of previously published and new records. Alekseev (2007) mentioned the species as a potential faunal component in KR. Based on Lentz's (1879) remark, the 230-year-old occurrence in the vicinity of present-day Kaliningrad [Königsberg] could be assigned to this species. The actual occurrence of the species in easternmost parts of $\mathrm{KR}$ is quite possible. IUCN Red List Category (EU) - VU.

\section{Genus Gnathacmaeops Linsley \& Chemsak, 1972}

产 G. pratensis (Laicharting, 1784)

Examined actual data. Absent. No material is available from $\mathrm{LT}$ and $\mathrm{KR}$.

Published local records. LT: The actual faunistic information is given on the occurrence of this species (Acmaeops) in Vilnius (Kinel, 1917; Zawadzki, 1937), Elektrènai, and Trakai (Ostrauskas, 2020) districts. KR: Lentz, 1879 (Pachyta strigilata); Bercio, Folwaczny, 1979; Alekseev, 2007, as improbable.

General distribution. It is distributed from Scandinavia to the Far East, Kamchatka; also known in northern Mongolia, China, and Korea. Additionally, this species was noted in the boreal regions of North America (Bousquet, 1991), but this statement was doubted by Danilevsky (2014). The species is widely distributed in northern Europe, the mountainous areas of the central part of Europe, and the Caucasus. 
Notes on biology. The larvae of this species develop under loose bark of the stems of dead coniferous trees but prefer spruce and pines. Mature larvae leave the host plant and overwinter in the litter. Pupation takes place in spring. Adults emerge mainly in the July; they are diurnal and anthophilous. The life cycle lasts two years (Palm, 1956). Some authors regarded this species as fire-adapted or pyrophilous (Moretti et al., 2010; Hjälten et al., 2017).

Local occurrence and phenology. The records of the species in LT are not confirmed by voucher material.

Comments. Zawadzki (1937) noted that 12 individuals of the species were collected in the environs of Vilnius, in May-June 19241927, on the blossom of Sorbus aucuparia and various Apiaceae; also, two records of this species were noted from the Elektrenai and Trakai districts by Ostrauskas (2020). However, the voucher material of these all records is not available and we cannot confirm these notifications. It has not been found during current research in KR and not known in the territory from the literature. Alekseev (2007) mentioned the species as a faunal component of the adjacent lands only. The occurrence of the species in the region could be expected only theoretically. The species was regarded as extremely rare (endangered) in eastern Poland (Gutowski, 1995). IUCN Red List Category (EU) - LC.

\section{Genus Pachyta Dejean, 1821}

P. lamed lamed (Linnaeus, 1758)

Examined actual data. LT: Alyt: Punios šilas, 27.06.2009, 1, RB (RBC); Pakr: Pakruojo miškas, 16.07.1971, 1, col. unknown (KZM); KR: no actual data.

Published local records. LT: The species is ranked as very rare and noted as distributed in central and eastern parts of the country by Pileckis, Monsevičius (1997). The actual faunistic information is known only from Ignalina district (Šablevičius, 2003). KR: Lentz, 1879 (lamed L., spadicea Pk.); Bercio, Folwaczny, 1979; Alekseev, 2007.

General distribution. It is distributed from Scandinavia to the Far East. The north- ern border of the distribution range goes to $68^{\circ} \mathrm{N}$ in Scandinavia and $66^{\circ} \mathrm{N}$ (Usinsk) in European Russia. The distribution of the species is restricted to the mountainous areas of southern Europe (Picard, 1929; Demelt, 1948; Pawlowski, 2008; Gobbi et al., 2012). Southwards, in the lowlands, this species is recorded from Belovezhskaya Pushcha, Belarus (Tsinkevich et al., 2005). The subspecies P. lamed liturata Kirby, 1837, is distributed in North America (Bousquet, 1991; Heffern, 1998; Rice et al., 2017), but its taxonomic status was doubted by Danilevsky (2014).

Notes on biology. The larvae of the species develop mainly in dead roots of Picea; pupation occurs in the ground near host roots. The life cycle lasts three years. Adults emerge in JuneJuly; they are diurnal and anthophilous. They have been observed on the blossom of Angelica sylvestris (Ehnström, Axelsson, 2002), Peucedanum spp. (Šablevičius, 2003), and Chamaenerion angustifolium (Karpiński et al., 2018).

Local occurrence and phenology. It is an extremely rare species in LT, apparently related to mature stands of spruce-dominated forests; recorded from five districts (Fig. 7). Not found during current research in KR. Historical records from KR [Gur: Königsberg, Zel: Warnicken] need futher verification.

Comments. This species is considered endangered in some European countries (Witkowski et al., 2003). IUCN Red List Category (EU) - EN.

\section{P. quadrimaculata (Linnaeus, 1758)}

Examined actual data. LT: Akm: Kamanu valstybinis gamtinis rezervatas, 15.07.1998, 1, BP; Užpelkiai, 08.07.1999, 1, VM; Alyt: Vanagèliai, 28.06.2018, 1, RF; Anyk: Katlèriai, 13-19.07.1985, 5, SK; ibidem, 08.07.1989, 1, SK; Traupis, 27.06.2020, 1 (6), SO; Drus: Druskininkai, -.06.1975, 1, SP; El: Semeliškès, 22.06.1974, 1, VM; Jona: Salupių miškas, 30.05.1963, 1, SP; Joni: Daunoravos miškas, 23.07.1998, 1, RB; ibidem, 07.07.2003, 1, RB; Maželių miškas, 07 07.2001, 1, RB; Nemeikšių miškas, 29.07.2003, 1, RB; Satkūnų miškas, 15.06.1999, 1, RB; Tyrelio miškas, 09.07.2005, 
2, RB; Voverkio miškas, 09.07.2005, 1 RB; Jurb: Kaskalnio miškas, 20.07.2000, 1, VU; Viešvilès miškas, 17.07.1957, 1, SP; K.R.: Ąžuolų Būdos miškas, 17.06.2020, 1, VT; Skriaudžiu miškas, 06.07.2018, 1 (Ф), VGl; Kaiš: Strošiūnų miškas, 10.06.2008, 1, VB; Pridotkai, 03.06.1989, 1, AM; Kau: Akademija, 17.06.1998, 2, VT; Dubravos miškas, 06.06.1981, 1, RF; ibidem, 30.06.1984, 3, RF; ibidem, 06.07.1985, 1, RF; ibidem, 29.06.1992, 1, RF; ibidem, 01.07.1992, 1, RF; Kamšos miškas, 04.07.1962, 1, SP; Karmèlavos miškas, 25.06.2004, 1, VI; Kaunas (Kleboniškio miškas), 25.06.2007, 1 (ब), GS; Papiškinès miškas, 12.07.2019, on blooms of Apiacea, 6, VT; Raudondvaris, 11.06.1972, 1, EG; ibidem, 13.06.1973, 1, RG; ibidem, 23.06.1974, 1, RG; Kup: Mirabelio miškas, 23.06.1991, 1, RP; Laz: Jukneliškè, 11.07.1985, 1, ASt; Maž: Mažeikiai, 03.07.2012, 1 (6), DM; Pag: Pagégių miškas, 26.06.2020, 1 (Ф), GM; Pas: miškas Didieji Grūžiai, 04.07.2004, 1, VB; miškas Girelè, -.07.1963, 1, SP; Moliūnų miškas, 09.08.2006, 1, VB; Rinkūnai, 09.07.2004, 1, VB; Rok: Dusetų miškas, 30.06.2004, 1, RF; miškas Juodalungè, 21.07.1972, 1, SP; Šal: Visinčios hidrografinis draustinis, 20.06.1985, 2, RF; Širv: Paversmès, 20.06.2020, 1 (C), AJu; Tau: Viešvilès valstybinis gamtinis rezervatas, 10.07.2000, 1, VU; ibidem, 08.07.2008, 1 (Ф), RF; Trak: Tamašava, 28.06.1997, 1, PI; Tolkiškès, 09.07.1979, 2, VUst; Ukm: Pageležiai, 29.07.1974, 1, RG; Šešuolių miškas, 15.06.2019, 1 (C), ŽP; Verškainių miškas, 15.06.2019, 1, KJ; Vilk: Grybingirio gamtinis rezervatas, 01.07.2020, 1, KM; miškas Drausgiris, 11.07.2011, 1, RF; Viln: Maišiagala (Kalniškès), 08.07.2007, 1, PI; ibidem, 28.0605.07.2009, 1, PI; Nemenčiné, 28.07.2019, 1 (Ф), JM; Paberžè (Medyna), 16.06.1917, 1, BH; Vilnius (Belmontas), 29.06.2020, AK; Vilnius (Santariškès), 21.07.2019, 1 (C), AJu; Vilnius (Verkių miškas), 01.07.2008, 1, PI; ibidem, 06.07.2018, 1, AJu; Vilnius (Žemasis Pavilnys), 29.06.2020, 1 (), TPo; Zar: Dusetos, 17.07.1979, 1, VUst; Salakas, 06.07.1979, 1, VUst; KR: Bagr: 3 km W Kamenka, 15.06.2019, 3 (D), VA; Chern: 7 km NE Cherniakhovsk, 10.07.1997, 1, VA; Pushkarevo, 26.06.2006, 1, VA; Pol: $2 \mathrm{~km}$ SE Fevral'skoe, 28.06.2020, 1 (Ф), VA; Zel: 2 km
N Medvedevka, 04.07.2010, 1, VA; 1 km NW Riabinovka, 08.07.2010, 1, VA; 2 km NE Kostrovo, 18.06.2018, 1 (Ф), VA.

Published local records. LT: This species is ranked as not rare and noted as distributed throughout the country by Pileckis, Monsevičius (1997). The actual faunistic information is given on the occurrence of the species in Vilnius (Zawadzki, 1937; Staniulisówna, 1939), Alytus, Kaunas (Tamutis, Zolubas, 2001; Ferenca, 2006), Panevėžys, Rokiškis (Ferenca, 2006), and Elektrenai (Ostrauskas, 2020) districts. KR: Lentz, 1879 (4-maculata); Bercio, Folwaczny, 1979; Alekseev, Sakhnov, 2002; Alekseev, 2006, 2007.

General distribution. It is distributed from Iberia to the western part of Amur region. The northern border of its distribution range reaches the southern provinces of Finland, Syktyvkar (Komi, Russia). It is known mainly from the mountainous areas in central and southern Europe. However, records are still missing from the Scandinavian and Crimean peninsulas, the southern part of European Russia, and the Caucasus.

Notes on biology. The larvae develop mainly in dead roots of Pinus sylvestris; pupation occurs in the soil near the host. Adults emerge in June-July; they are diurnal and anthophilous, visiting the blossom mainly of Apiaceae, Knautia, Spirea, and Sambucus. The life cycle lasts three years.

Local occurrence and phenology. The species is quite common in the Pinus sylvestrisdominated forests in LT, but is still lacking actual records from the coastal region of the Baltic Sea. Recorded from 33 districts in the region (Fig. 8); the maximum of observed adults was in July, the earliest observation on 30 May, the latest on 9 August.

Comments. IUCN Red List Category (EU) - LC.

\section{Genus Pidonia Mulsant, 1863}

\section{P. (s. str.) lurida (Fabricius, 1787)}

Examined actual data. LT: Kau: Jiesios kraštovaizdžio draustinis, 01.06.2008, 1, VI (KZM); Kamšos miškas, 14.06.1995, 4, in 


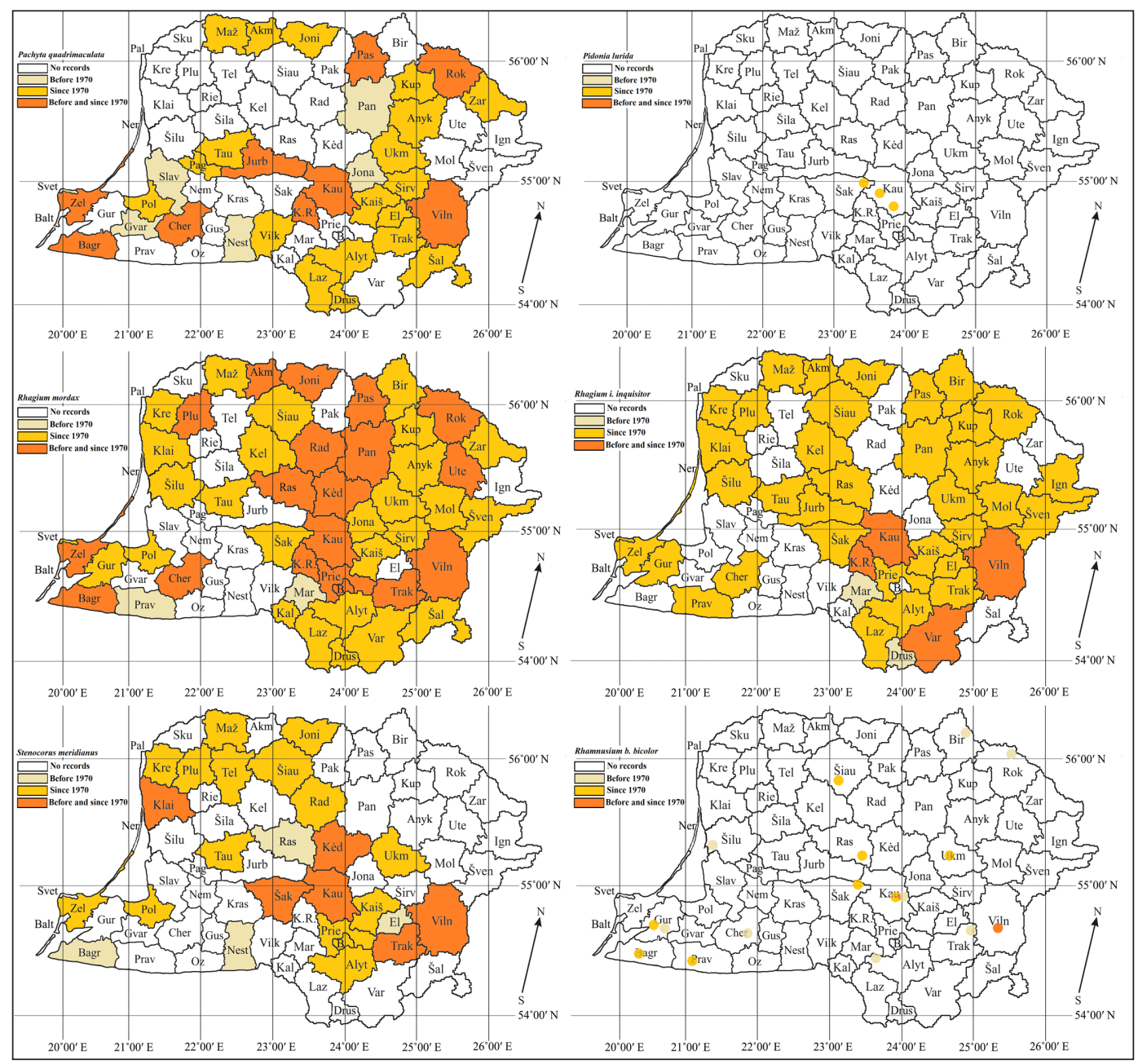

Fig. 8. Maps of distribution of Pachyta quadrimaculata, Pidonia lurida, Rhagium mordax, Rhagium i. inquisitor, Stenocorus meridianus and Rhamnusium b. bicolor (Coleoptera: Cerambycidae: Lepturinae) in south-eastern Baltic region

deciduous forest edge on blossom of Apiaceae, VT (KZM); Šak: miškas Juškinè, 16.06.2015, 1, RF (KZM); Tervydoniai, 16.06.2009, 1, RF (KZM); KR: no actual data.

Published local records. LT: The actual faunistic information was given on the occurrence of this species in Kaunas district (Tamutis, 2003; Inokaitis, 2009) KR: Alekseev (2007), as improbable.

General distribution. The species occurs in Europe, from eastern France to Latvia, Lithuania, Poland, Ukraine, and Moldova (Burakowski et al., 1990; Sama, 2002; Tamutis, 2003; Bartenev, 2009; Telnov, 2004; Danilevsky, 2014). The record of this species in the environs of Jaunpiebalga (Latvia) (Mičulis, 1986) seems to be northernmost. Southwards, this species was observed in northern Italy, Serbia, and Greece.

Notes on biology. The life history of this species is not completely known. According to Švácha (1989), the life cycle lasts two years; larvae feed under the bark of dead shallow roots and leave the feeding substrate before their last hibernation, overwintering and pupating in the soil. Probably polyphagous; however, the larvae have been found only on Picea and Fagus. Adults appear in May-June; they are diurnal and anthophilous.

Local occurrence and phenology. It is local distributed and rare in LT, recorded only from the central part of the country (Fig. 8). Still not found in KR. 
Comments. Alekseev (2007) doubted the possible occurrence in $\mathrm{KR}$ and mentioned the species as a faunal component of the adjacent lands only. It is a rare species across its entire distribution range (Dodelin et al., 2017) and has not been found yet in northern Poland and Belarus. IUCN Red List Category (EU) - LC.

\section{Genus Rhagium Fabricius, 1775 \\ - Rh. (Hagrium) bifasciatum Fabricius,} 1775

Examined actual data. Absent. No material is available from LT and KR.

Published local records. LT: No actual published records; however, it is listed in some catalogues (Sama, 2002; Danilevsky, Smetana, 2010; Danilevsky, 2019). KR: Lentz, 1879; Bercio, Folwaczny, 1979; Alekseev (2007), as improbable.

General distribution. The species occurs only in the western and southern parts of Europe. The distribution range extends from Iberia and the British Isles to the western part of Ukraine, Moldova, the western part of Caucasus, Anatolia, and Iran; northwards, it goes as far as Denmark; the records from southern Norway are dubious (Naturhistorisk Museum, 2009). The actual data on the distribution of this species in eastern and north-eastern Europe are still missing.

Notes on biology. This species is polyphagous on both coniferous and deciduous trees. The larvae develop in moist decaying wood; unlike other species of the genus, they are not subcorticolous. The life cycle lasts two to three years. Pupation occurs inside wood in summer. Adults owerwinter and emerge in spring; they are diurnal, usually crawl on fallen trunks, and occasionally visit flowers.

Local occurrence and phenology. No actual information in the region.

Comments. One historical record from the studied region [Friedland, i.e. present-day Pravdinsk] (Bercio, Folwaczny, 1979) should be interpreted as an occasional introduction of the species in the past. Based on the information on the easternmost records of this species
(Gutowski, 1995), we doubt the occurrence of this species in the region. IUCN Red List Category (EU) - LC.

Rh. (Megarhagium) mordax (DeGeer, 1775)

Examined actual data. LT: Akm: Kamanu valstybinis gamtinis rezervatas, 07.07.1980, 1, VM; ibidem, 02.08.1998, 1, BP; Alyt: Vidzgirio botaninis draustinis, 05.06.1998, 1, RF; Punios šilas, 06.09.2018, under bark of dead Quercus robur, 6 larvae, VT; ibidem, 09.04.2020, 1 (Ф), KM; Zizènai, 29.05.2020, 1 (D), GJ; Anyk: Anykščiai, 07.06.2020, 1 (D), RG; Anykščių šilelis, 17.06.2020, 1 (D), RG; Katlèriai, 08.07. 1984, 1, SK; Niūronys, 27.07.2019, under bark of log of Betula pendula, 5 larvae, 1 pupa, VT; ibidem, 28.07.2019, under bark of $\log$ of $Q$. robur, 6 larvae, VT; Paandrioniškis, 05.06.2020, 1 (D), LM; Svèdasai, 09.05.2020, 1 (()), EČ; Troškūnų miškas, 29.03.2020, 1 (D), SO; Želtiškiai, 13.06.2009, 1 (Ф), AE; ibidem, 23.05. 2010, 1 (), AE; B: Birštonas, 03.06.1934, 1, KA; Žverinčio miškas, 23.05.2020, 1 (D), LMa; Bir: Biržų giria, 20.03.2020, under bark of dead Fraxinus excelsior, 3, VT; Kirkilų miškas, 07.09.2019, under bark of fallen, dead F. excelsior, 3 larvae, VT; Ločiai, 27.05.2020, 1 (6), RR; Rumbos, 31.05.2020, 1 (D), IV; Drus: Vileikiai, 05.05.2013, 1, RK; Jona: Būdos miškas, 09.05.2011, 1, RF; Kaušankos miškas, 04.07. 2020, 1 (Ф), obs. unknown; Ručiūnai, 19.07.2017, 1 (Ф), JZ; Rukla, 22.05.2016, 1 (Ф), SD; Joni: Satkūnų miškas, 19.05.1998, 1, RB; ibidem, 121.05.1999, 1, RB; ibidem, 27.04-29.05.2000, 3, RB; Žagarès miškas, 27.06.2005, 1, RB; Kaiš: Būdos miškas, 18.06.2020, 2, on blooms of Apiaceae, VT; Burbiškès, 06.05.2012, 1 (D), AJu; Burčiakų miškas, 25.05.2007, 2, RF; Pravieniškès, 02.05.1989, 1, AM; Strévininkų miškas, 18.05.2006, 2, RF; ibidem, 23.05.2007, 1, RF; Strošiūnų miškas, 06.05.2010, 1, APa; ibidem, 12.05.2018, 1 (Ф), KJa; Vaiguvos miškas, 27.05.2003, 1, RF; Kal: Juodeliai, 29.05.2002, 1, RF; Kau: Akademija, 10.05.2018, 1, VT; Babtu miškas, 07.06.2020, 1 (D), obs. unknown; Braziūkai, 10.08.2008, 1, VT; ibidem, 06.05. 2016, on blooms of Prunus domestica, 1, VT; Dievogala (Palankiai), 10.04.1926, 1, PRé; Dubravos miškas, 15.06.1956, 3, SP; ibidem, 
28.06.1981, 2, RF; ibidem, 09.07.1984, 1, RF; ibidem, 19.06.1985, 1, RF; ibidem, 01.05.1989, 1, RF; ibidem, 30.04.2018, under bark of stump of B. pendula, 1 larva, RF; Ežerèlis, 30.05.2020, 1 (D), GUm; Gaižènai, 25.04.1996, 1, VT; Jiesios kraštovaizdžio draustinis, 01.06.1978, 1, RF; ibidem, 25.05.1981, 1, RF; ibidem, 28.05.1982, 1, RF; ibidem, 28.05.1998, 1 RF; ibidem, 23.04.2000, 1, RF; ibidem, 05.05.2016, 1 (6), RF; Kačerginès miškas, 28.06.1962, 3, EG; ibidem, 06.07.1962, 1, EG; ibidem, 15.07.1965, 2, SP; Kamšos miškas, 29.04.1953, 1, EG; ibidem, 20.05.1953, 1, EG; ibidem, 15.06.1996, 2, VT; ibidem, 13.07.1996, 1, VT; ibidem, 12.06.1997, 1, VT; ibidem, 17.06.1997, 1, VT; Kaunas (Kleboniškio miškas), 15.07.1955, 1, SP; ibidem, 05.04.2010, 1 (D), GS; Kaunas (Pažaislio šilas) 09.03.2014, 1 (Ф), GS; Linksmadvaris, 26.05.1925, 1, AP; Lomankos miškas, 05.06. 2014, 1, VI; Nevėžio kraštovaizdžio draustinis, 23.04.2018, 1, RF; Raudondvaris, 25.03.1974, 1, EG; Ringaudai, 27.03.2020, 1 (Ф), RS; Ringovès entomologinis draustinis, 24.08.2018, 1 pupa (Ф), RF; Viršužiglis, 09.05.2020, 1 (()), AŽu; Kel: Katežeris lake environs, 22.05.2010, 1 (Ф), DB; Tolučiai, -.07.1981, 1, VUst; Kèd: Medininkai, 06.06.2020, 1 (Ф), DP; Petkūnai, 11.11.2018, 1 (D), KV; Vilainių miškas, 17.05.2008, 1, col. unknown; Klai: Giruliai, 29.06.1985, 1, SK; Klaipèda (Žardè), 14.06.2020, 1 (D), KK; Kliošiai, 25.06.2017, 1 (Ф), ZG; Smiltynè (Hageno kalnas), 01.09.2018, under bark of dead $P i$ nus sylvestris, 1, VT; K.R.: Braziūkų miškas, 13.04.2018, under bark of dead Alnus glutinosa, 3 larvae; ibidem, 29.08.2018, under bark of stump of B. pendula, 5 larvae, 2 pupae, 1 adult, VT; Jūrès miškas, 29.04.1998, 1, RF; Kazlų Rūda, 20-30.08.1965, 2, EG; ibidem, 25.08.1979, 1, EG; Kazlų Rūdos kraštovaizdžio draustinis, 08.02.2020, under bark of dead A. glutinosa, 2, VT; Kurynè, 05.04.2020, 2 larvae, VT; Prūsokai, 28.04.2015, 1, RF; Kret: Kulupènai, 30.05.2020, 1 (C), LPr; Kup: Stirniškiai, 26.08.1990, 1, RP; Laz: Bijotų miškas, 09.07.2020, 1 (D), JL; Rinkoto miškas, 08.05-09.06.2020, "window" trap, 1, VT; Mar: Varnabūdès miškas, 15.06.1961, 1, col. unknown; Maž: Krakiai, 15.06.2009, 1 (Ф), AVi; Maigių miškas, 30.06.2013, 1 (Ф), DM;
Mažeikiai, 22.05.2020, 1 (Ф), obs. unknown; Mol: Aparai, 06.06.2020, 1 (Ф), ML; Molètai, 0221.07.1972, 5, EG; Šakimo miškas, 28.05.2018, 1, RF; Pan: miškas Rekstinas, 10.05.2020, 1 (D), AV; Raguva forest district, 15.09.1961, 1, col. unknown; Pas: miškas Ąžuolynè, 10.05.2006, 1, VB; Januškai, 06.05.2004, 1, VB; Joniškèlis, 15.07.1963, 1, col. unknown; miškas Lepšynè, 19.06.2007, 1, VB; Nairiai, 31.05.2020, 1 (6), obs. unknown; Rinkūnai, 27.04.2005, 1, VB; Žoliškių miškas, 04.05.2006, 1, VB; Plu: Plateliai, 15.06.1963, 1, col. unknown; Plokštinès miškas, 12.08.2020, 3 larvae, VT; Prie: Verknè (Stakliškès) forest district, 15.07.1960, 1, col. unknown; Bačkininkų miškas, 01.07.1984, 1, RF; Balbieriškio miškas, under bark of dead Q. robur, 5 imago, 3 larvae, VT; Mažosios Zariškès, 14.05.2017, 1 (Ф), VGl; Rad: Ilguočiai, 21.06.2020, 1 (D), obs. unknown; Radviliškis forest district, 15.07.1960, 2, SP; Verduliai, 22.05.2020, 1 (D), RV; Ras: Bedančiai, 26.05. 2018, 1 (Ф), GM; Betygala, 13.06.2020, 1 (C), obs. unknown; Lapkalnio miškas, 15.08.1961, 1, col. unknown; Plauginių miškas, 19.06.2020, 1 (D), obs. unknown; Rok: Suvainiškis, 27.05. 2020, 1 (Ф), obs. unknown; Šak: Plokščiai, 09.05.2009, 1, RSa; Sudargo miškas, 12.06.2020, 1 (क), LSt; Tervydoniai, 02.05.2010, 1, RF; ibidem, 15.04.2018, under bark of dead Malus domesticus, 1 larva, RF; ibidem, 20.10.2018, 2, RF; Šal: Baltoji Vokè, 19.05.2019, 1 (D), AJu; Šiau: Parkulpio miškas, 16.07.1998, 1, RF; Slydžiai, 16.05.1998, 1, VT; ibidem, 01-25.04.2000, under bark of dead Q. robur, 3, VT; Šilu: Joniškio miškas, 01.09.2020, 1, RF; Širv: Kernave, 06.06.2020, 1 (Ф), obs. unknown; Šven: Antanų miškas, 20.06.2001, 1, RF; Veikūnų miškas, 06.06.2020, 1 (Ф), AV; Tau: Buveiniai, 12.06.2000, 1, VU; ibidem, 02.05.2001, 1, VU; Eičių miškas, 14.07.1992, 1, RF; ibidem, 21.05.1993, 1, RF; ibidem, 04.06.2017, RPa; Ringaliai, 19.06.1998, 1, VU; Viešvilès valstybinis gamtinis rezervatas, 15.05-16.06.2001, 2, VU; Trak: Jogèloniu miškas, 26.07.2020, pheromone trap for Ips typographus, 2, DMa; Spindžiaus miškas, 31.05.2020, 1 (Ф), obs. unknown; Tolkiškès, 30.06. 1978, 1, VUst; Trakai, 15.07.1960, 1, SP; Valai, 23.05.2020, 1 (D), obs. unknown; 
Varnikai, 30.05.2020, 1 (D), AŠ; ibidem, 04.04.2020, 1 (Ф), ŽP; Ukm: Laumènų miškas, 12.05.2008, 1 (Ф), KJ; Mašinių miškas, 12.06.2020, 1 (D), KJ; Ukmergè, 04.12.2007, TP; Ute: Butiškiai, 01.06.2020, 1 (Ф), KŠ; Moniškis, 18.06.2019, 1 (D), EČ; Utena, 01.06.1964, 1, EG; Tauragnai, 11.06.2020, 1 (), TPo; Var: Čepkelių rezervatas, 19.06.1976, 1, VMo; Latežeris, 21.08.1977, 4, EG; Marcinkonys, 27.05.2017, 1, KVie; Merkinè, 11.05.1981, 1, VUst; Palkabalių miškas, 12.05.2016, 3, VT; Pauosupès miškas, 09.09.2020, under bark of B. pendula 1, KM; Puvočiai, 04.07.2004, 1, VUst; Viln: Aukštagirio miškas, 08.06.2020, 1 (D), JJ; (Santakos miškas), 10.05.2020, 1 (ד), VBa; Danilava, 30.04.2000, 1, PI; Karmazinai, 27.06.2003, 1, RF; Kryžinè, 06.06.2020, 1 (D), EP; Maišiagala (Kalniškès), 08-13.06.2006, 2, PI; ibidem, 27.06.2006, 1, PI; ibidem, 21-28.04.2008, PI; ibidem, 26.0502.06.2008, Malaise trap, 2, PI; 19-26.10.2008, Malaise trap, 4, PI; ibidem, 17.05-02.06.2009, "wine" trap, 9, PI; ibidem, 06.06.2011, 1, PI; ibidem, 16.05.2014, 1, PI; ibidem, 18.0423.06.2015, "window" trap, 6, PI; Paberžè (Medyna), 15.06.1918, 1, BH; Suktiškių miškas, 01.05.2018, 1 (Ф), ŽP; Vilnius, 15.05.1966, 1, ASt; Vilnius (Paneriai), 23.05.1973, 1, PI; Vilnius (Pavilnių regioninis parkas), 25.11.2019, 1 (D), AK; Vilnius (Santariškès), 27.05.2020, 1 (C), GČ; ibidem, 17.06.2020, 1 (D), PP; ibidem, 21.06.2020, 1 (Ф), EV; Vilnius (Verkių miškas), 27.06.2006, 1, PI; ibidem, 28.04.2008, 1, DSt; ibidem, 17.05.2008, 3, DSt; ibidem, 31.05.2020, 1 (D), obs. unknown; Vilnius (Vingio parkas), 30.04.2015, 1 (Ф), OV; Zar: Jaskoniškių miškas, 06.05.2004, 3, RF; KR: Bagr: 1 km E Ladushkin, 12.04.2009, 1, VA; ibidem, 02-19.05.2009, 1, VA; Cher: 8 km NE Cherniakhovsk, 05.04.2008, 1, VA; Pushkarevo, 26.06.2006, 1, AV; 4 km NE Cherniakhovsk, 10.06.2020, 1 (Ф), VA; Gur: Otvazhnoe, 30.03.2003, 1, VA; Chkalovsk, 04.04.2009, 1, VA; 1 km W Kaliningrad, 14.06.2020, 2 (Ф), VA; Pol: Sosnovka, 22.06.2010, 1 (D), VA; ibidem, 10.05.2016, 1 (D), VA; ibidem, 12.06.2019, 1 (क), VA; ibidem, 26.06.2019, 1, VA; Svet: Filino, 24.06.2020, 1 (D), VA; Zel: Zelenogradsk, 10.06.2000, 1, VA; Riabinovka,
20.06.2010, 2, VA; Dubki, 28.03.2014, 1, VA; $3 \mathrm{~km}$ W Kolosovka, 15.03.2001, 1, VA.

Published local records. LT: This species is ranked as very common and noted as distributed throughout the country, excluding the coastal region of the Baltic Sea by Pileckis, Monsevičius (1997). The actual faunistic information is given on the occurrence of this species in Vilnius (Zawadzki, 1937 (Magarhagium mordax Deg.); Staniulisówna, 1939), Alytus (Tamutis, Zolubas, 2001), Kaunas, (Gedminas, 2005; Ferenca, 2006), Birštonas, Rokiškis, Trakai (Ferenca, 2006), Lazdijai (Ostrauskas, Tamutis, 2012), Švenčionys, and Zarasai (Ostrauskas, 2020) districts. KR: Lentz, 1879 (inquisitor Fabr.); Bercio, Folwaczny, 1979; Alekseev, Sakhnov, 2002; Alekseev, 2006, 2007.

General distribution. It is distributed from the northern part of Iberia to the Altai (Tomsk region, Russia). The northern border of its distribution range goes to $68^{\circ} \mathrm{N}$ in Scandinavia and $64^{\circ} \mathrm{N}$ in European Russia. Its distribution is restricted in the mountainous areas of southern Europe; so far, it has not been found in the Crimean Peninsula and the Caucasus region.

Notes on biology. This species is polyphagous, but, contrary to Rh. inquisitor, demonstrates a strong preference for deciduous trees, especially Betula, Quercus, Fraxinus, Fagus, Alnus, Salix, Acer, and Tilia; it ingabits Pinus or Picea only rarely. The larvae develop under the bark of dead trees over two to three years and pupate in late summer or autumn; pupal cells are found in the bark and are not surrounded by a barrier of elongated wooden fibres. Adults appear in autumn and hibernate in pupal cells.

Local occurrence and phenology. It is one of the most common and easiest-to-observe species of long-horned beetles in the region. The adults can be found all year round. It is widely distributed in the forests and parks throughout the region; recorded from 50 districts (Fig. 8).

Comments. Despite the wide polyphagia of this species, only one record was made from coniferous trees in the region during the study. IUCN Red List Category (EU) - LC. 
$R h$. (s. str.) inquisitor inquisitor (Linnaeus, 1758)

Examined actual data. LT: Akm: Kamanu valstybinis gamtinis rezervatas, 03.07.1980, 1, VM; Alyt: Punios šilas, 06.09.2018, under bark of dead Picea abies, 3, VT; Anyk: Anykščiai (Jurzdikas), 05.03.2020, 1 larva (C), SO; Bir: Bèčiūnai, 25.03.2020, 1 larva (⿻), RR; Biržų giria, 07.04.2012, 1, ED; Likènų parkas, 08.09.2019, under bark of dead P. abies, > 10 larvae, 1 adult, VT; Drus: Druskininkai, 27.08.1969, 1, EG; Ign: Ažvinčių giria, 29.0519.06.2013, “window" trap, 1, VT; Joni: Satkūnų miškas, 09.05.1998, 2, RB; ibidem, 19.06.1998, 1, RB; ibidem, 29.04.2000, 1, RB; ibidem, 13.05.2001, 1, RB; 18.06.2002, ibidem, 1, RB; ibidem, 16.06.2009, 1, RB; Jurb: Viešvilès valstybinis gamtinis rezervatas, 24.04.2002, 1, VU; Kaiš: Kruonis, 03.07.2005, 1, AM; Pravieniškès, 24.05.1976, 1, AM; Srèvininkų miškas, 09.09.2001, 1, VT; ibidem, 18.05.2006, 2, RF; Strošiūnų miškas, 04.12.2007, 1, DSt; ibidem, 05.04.2008, 1, DSt; ibidem, 03.07.2009, 1, DSt; Triliškès, 05.04.2008, 1, DSt; Kau: Braziūkų miškas, 10.02.2008, 2, VT; ibidem, 04.04.2018, under bark of dead P. sylvestris, 10, VT; Dubravos miškas, 29.04.1983, 1, RF; ibidem, 13.08.1983, 1, RF; ibidem, 29.04.1984, 1, RF; ibidem, 24.05.1986, 2, RF; ibidem, 08.06.1986, 1, RF; Ežerèlis, 06.10.1985, 1, RF; Gervènupis, 12.07.1972, 6, EG; Jiesios kraštovaizdžio draustinis, 07.05.2002, 1, RF; Kačerginès miškas, 21.03.2020, 1 (Ф), RS; ibidem, 01.04.2020, 1 (D), RS; Lomankos miškas, 31.05.2014, 1, VI; Panemunès šilas, 25.08.1981, 4, RF; Raudondvaris, 28.07.1973, 1, EG; ibidem, 25.03.1974, 3, EG; Kel: Patrališkè, 26.04.2009, 1 (d), LMo; Klai: Dreverna, 13.05.2018, 1 (Ф), TL; Šernai, 14.06.1985, 6, SK; K.R.: Kazlų Rūda, 10.08.1961, 1, EG, Jūrès miškas, 29.04.1998, 7, RF; Braziūkų miškas, 28.01.2017, under bark of dead P. abies, $>10$, VT; Kup: Šimonių giria, 22.09.1990, 1, RP; Laz: miškas Trakas, 19.06.2020, 1 (()), VEB; Maž: Balènos, 20.05.2020, 1 (D), MB; Krakiai, 15.06.2009, 1 (D), AVi; ibidem, 15.05.2010, 1 (D), AVi; Mol: Bijutiškis, 10.09.2014, 1 (6), GM; Šližiškiai, 12-15.05.2017, 1, KČ; Ner: Grobšto gamtinis rezervatas, 24.05.2006, 2, RF; Hage- no kalnas, 05.09.2018, under bark of dead P. sylvestris, $>10$ larvae and 5 pupae, VT; Pan: Naujamiestis, 20.07.1982, 1, VUst; Pas: miškas Didieji Grūžiai, 05.04.2004, 1, VB; Rinkūnų miškas, 11.10.2005, 1, VB; Žadeikių miškas, 10.10.2004, 1, VB; Žalioji giria, 04.05.2004, 1, VB; Plu: Plokštinès miškas, 12.09.2019, under bark of dead $P$. abies, $>10$ larvae, 2 pupae and 3 imagines, RF; Prie: Balbieriškio miškas, under bark of $P$. abies, 3 imago, 5 larvae, VT; miškas Gojus, 16.04.2009, 1 (Ф), RF; Norkūnai, 07.05.2020, 1 (), TPo; Skerdupis, 05.09.1981, 7, col. unknown; Ras: Bedančiai, 26.05.2018, 1 (D), GM; Rok: Stasiūnai, 29.04.2019, 1 (D), PA; Šak: miškas Juškine, 07.10.2000, 1, RF; Šakiai, -.07.1972, 1, VUst; Šiau: Bazilionai, 21.08.2020, under bark of dead P. sylvestris, $>10$ pupae and larvae, VT; Slydžiai, 07.05.2016, observed flaying, 1, VT; Mirskišké, 31.08.2019, under bark of fallen logs of $P$. sylvestris, $>30$ larvae, 1 pupa, VT; Bubių miškas, 07.10. 2019, under bark of stump of $P$. abies, 6, VT; Paširvio miškas, 16.02.2020, 5, under bark of dead P. abies, VT; Šilu: Žemaičių Naumiestis, 12.06.2020, 1 (D), KK; Širv: Bartkuškio miškas, 26.03.2020, lot of pupal cells on Pinus sylvestris, (Ф), JM; Šven: Dvarčiškiai, 09.05.2020, 1 (D), ARi; Sariai, 0919.05.2020, 2 (Ф), obs. unknown; Tau: Artoji pelkè, 06.05.1996, 1, VU; ibidem, 24.04.1998, 1, VU; Pasalupis, 21.042014, 1 (D), GS; Viešvilès valstybinis gamtinis rezervatas, 20.05.1993, 1, RF; Trak: Jogèlonių miškas, 26.07.2020, pheromone trap for Ips typographus, 1, DMa; Ropejų miškas, 06.05.2004, 1, BP; Spindžiaus miškas, 05.05.2012, 1 (D), ŽP; Ukm: Adomiškio miškas, 12.05.2010, 1 (D), GS; Laumènų miškas, 16.06.2020, 1 (), KJ; Ukmergé, 21.04.1984, 1, AU; Šaltupio miškas, 23.04.2019, 1 (D), GP; Vyžuonų miškas, 02.04.2020, under bark of P. sylvestris, >10 larvae, VT; Var: Latežeris, 26.08.1969, 1, EG; Lynežeris, 22.04.1992, 1, RF; Marcinkonys, 06.06.1984, 1, RF; ibidem, 16.05.2012, 1, VMUst; ibidem, 27.05.2017, 1, DT; miškas Paliepè, 07.09.2015, 1 pupa (D), RF; ibidem, 12.07.2018, 1, VI; Pamerkio miškas, 11.06.2020, 1 (Ф), APe; Purplių miškas, 12.03.2019, 1 larva (ब), TPo; Puvočiai, 17.05.2012, 2, VMUst; Viln: Dūkštų miškas, 
15.01.2020, 1 (Ф), AJu; Elniakampio miškas, 18.05.2018, 1 (Ф), GM; Maišiagala (Kalniškès), 08-27.05.2006, 3, PI; ibidem, 19.04.2014, 1, PI; Mickūnai, 05.04.2016, 1 (), ŽP; Veliučionys, 11-17.04.1971, 3, AMa; ibidem, 21.03.1972, 2, AMa; ibidem, 23.05.1972, 12, AMa; Vilnius (Kryžiokų miškas), 30.09.2017, 1 (Ф), ŽP; Vilnius (Lazdynai), 03.04.1976, 4, AMa; Vilnius (Pavilnių regioninis parkas), 16.10.2019, 1 (C), GVi; Vilnius (Sapieginè), -.08.1974, 1, col. unknown; KR: Cher: Cherniakhovsk, 10.03.1993, 1, VA; Gur: Chkalovsk, 04.04.2009, 2, VA; Prav: Zehlau Bog, 18.09.2020, 1 (Ф), VA; Svet: $1 \mathrm{~km}$ W Svetlogorsk, 16.03.2003, 1, VA; ibidem, 23.05.2016, 1 (Ф), VA; Zel: Zelenogradsk, 18.05.2002, 1, PA; Pereslavsloe, 23.04.2007, 1, VA; Kolosovka, 13.04.2009, 1, VA; Kostrovo, 30.05.2016, 1 (()), VA; ibidem, 05.06.2019, 1 (6), VA; Kremnevo, 12.07.2020, 1 (D), VA.

Published local records. LT: This species is ranked as common and noted as distributed throughout the country, excluding the coastal region of the Baltic Sea by Pileckis, Monsevicius (1997). The actual faunistic information is given on the occurrence of this species in Vilnius (Zawadzki, 1937 (Harpium inquisitor); Staniulisówna, 1939, Ostrauskas, 2020), Alytus, Kaunas (Tamutis, Zolubas, 2001), Kazlų Rūda, Marijampolè (Ferenca, 2006), Klaipèda, Lazdijai (Ostrauskas, Tamutis, 2012), and Elektrenai (Ostrauskas, 2020) districts. KR: Lentz, 1879 (indagator Fabr.); Bercio, Folwaczny, 1979; Alekseev, Sakhnov, 2002; Alekseev, 2006, 2007.

General distribution. It is distributed throughout the Palaearctic region from Iberia and Great Britain to the Far East. The northern border of the distribution range goes to $68^{\circ} \mathrm{N}$ in Scandinavia and $63^{\circ} \mathrm{N}$ in European Russia. The southernmost records of this species are known in the mountainous areas of Morocco (Benyahia et al., 2016), Algeria, Turkey, northern Kazakhstan, Mongolia, and China. The occurrence of this species in North America (Linsley, Chemsak, 1972) was doubted by Danilevsky (2014). Five subspecies are designated and included in Danilevsky's (2019) catalogue of Palaearctic Cerambycoidea.
Notes on biology. This species is polyphagous, but strongly prefers coniferous trees: Picea, Pinus, Abies, and Larix. Larvae rarely develop on Betula, Quercus, and Fagus. Larvae develop within two to three years. Pupation occurs under the bark, in special cells, slightly entered the bark and surrounded by a barrier of long wooden fibres, from the end of July to September. Adults hibernate in pupal cells and become active in May-June, predominantly in daytime. Females lay eggs on the bark of dying or freshly dead trees, fallen or felled timbers, and stumps.

Local occurrence and phenology. It is widely distributed and one of most common easiest-to-observe species of long-horned beetles in the region; recorded from 42 districts (Fig. 8). The adults can be observed all year round. In the regional literature, the species is listed among the "main pests of pines" (e.g. Žiogas, 1997), but actually it inhabits dying or dead trees exclusively and does not cause real damage or have any economic importance.

Comments. Despite the large number of designated host plants, during the study, the larvae and pupae of this species were found under the bark of dead P. abies and P. sylvestris only in the investigated region. IUCN Red List Category (EU) - LC.

\section{Rh. (Megarhagium) sycophanta (Schranck, 1781)}

Examined actual data. LT: Kau: Kaunas (Aleksotas), 02.06.1927, 1, AP (KZM); Kaunas (Kleboniškio miškas), 03.07.1956, 1, SP (KZM); KR: no actual data.

Published local records. LT: This species is ranked as rare and distributed throughout the country, excluding the coastal region of the Baltic Sea, by Pileckis, Monsevičius (1997). The actual faunistic information on the occurrence of this species is given only from Kaunas district (Pileckis, 1958; Ferenca, 2006) and the voucher specimens were re-examined by authors. KR: Lentz, 1879 (mordax Fabr.); Bercio, Folwaczny, 1979; Alekseev, 2007.

General distribution. It is distributed from southwestern Iberia, Great Britain, and Ireland 
to the Urals. The northern border of its distribution range goes throughout the southern provinces of Sweden, Latvia (old data only), Belarus, Moscow and Perm regions (Russia), and the Tatarstan Republic (Russia). This species is widely known from southern Europe; however, its presence in Turkey (Alkan, Eroğlu, 2001), the Caucasus, and Siberia (Plavilstchikov, 1936) were doubted by Danilevsky (2014).

Notes on biology. The species is largely polyphagous on deciduous trees but prefers Quercus. Larvae develop in decaying wood. Švácha (1989) indicated that larvae strongly prefer the base of roots and generally live underground. Adults hibernate in pupal cells and emerge in spring. The life cycle lasts two years.

Local occurrence and phenology. The species seems to be endangered in the region. The last reliable record goes back more than 60 years. There are only historical records [Balt: Neuhäuser, Cher: Insterburg, Gur: Lauth, Nem: Tilsit] in KR.

Comments. Our study allowed us to specify the distribution of this species in LT and partially negate the position of Pileckis, Monsevičius (1997), who claimed that this species is distributed in almost entire territory of the country. Previous notification of this species in Vilnius district was based on a wrong interpretation of information published by Zawadzki (1937), who noted its occurrence in [Barowo] (in the district of Navahrudak, Belarus). Unfortunately, we could not confirm other records listed on the manual index card of Pileckis as "1963.VII. Joniškèlis Radviliškiui, leg. Urbelis", "1964.VI.8. Druskininkai", "1964.VII.16. Varènos apyl., and "1965.VII.3. Varniai", because the voucher material was lost. Most likely, those records belong to $R h$. mordax. IUCN Red List Category (EU) - LC.

\section{Genus Stenocorus Geoffroy, 1762}

S. (s. str.) meridianus (Linnaeus, 1758)

Examined actual data. LT: Alyt: Punios šilas, 22.06.2017, 1, RF; $B$ : Nemajūnų šilas, 21.06.2009, 1 (C), VaG; El: Vievis, -.07.1964, 1, SP; Joni: Satkūnų miškas, 19-25.06.1998, 4, RB; ibidem, 20.07.2000, 1, RB; Nemeikšiu miškas,
19.06.2000, 1, RB; Kaiš: Kruonis, 27.06.1976, 1, AM; Strošiūnų miškas, 05.05.2008, 1, DSt; ibidem, 02.06.2008, 1, VB; ibidem, 15.06.2008, 1, DSt; Kau: Dubravos miškas, 18.06.1957, 1, SP; ibidem 27.06.1958, 1, SP; ibidem, 12.07.1981, 1, RF; Gervenupis, 27-28.07.1973, 2, EG; Jiesios kraštovaizdžio draustinis, 13-26.06.1981, 2, RF; ibidem, 16.06.-21.07.1984, 3, RF; ibidem, 17.06.2000, 1, RF; ibidem, 23.06.2004, 1, RF; ibidem, 24.06.2005, 1, RF; ibidem, 18.06.2005, 1, AM; Kamšos miškas, 13.07.1996, 1, VT; Kaunas, 18.06.1978, 1, RF; Kaunas (Freda), 1823.06.1981, 2, RF; ibidem, 02.06.1984, 1, RF; Lomankos miškas, 16.06.2014, 1, VI; Noreikiškès, 24.06.1962, 1, SP; Pilènų miškas, 23.06.2016, 1, VI; Raudondvaris, 22.06.- 28.06.1972, 12, ibidem, 07.06.-13.06.1973, 7, EG\&RG; ibidem, 20.06.2002, 1, VI; Turžènų miškas, 13.06.2011, 1, VI; Kèd: Dotnuva, 12.07.1963, 1, SP; Klai: Klaipeda, 02.06.1965, 1, SP; Šernai, 17.06.1989, 2, SK; Kret: Kūlupènai, 13.06.1989, 4, SK; Maž: Renavas, 01.07.1991, 1, VM; Ukrinai, 10.06.2019, 1 (Ф), IL; Prie: Bačkininkų miškas, 01.07.1984, 1, RF; Rad: Pašušvio miškas, 23.06.2018, 1 (Ф), AKul; Ras: Vidukle forest district, -.06.1962, 1, SP; Šak: Baltkojai forest district, -.07.1961, 1, SP; Tervydoniai, 01.06.2014, 1, RF; Šiau: Bubių miškas, 23.06.1996, 1, VT; Tel: Varniai, -.06.1974, 1, SP; Tau: Bijotų miškas, 27.06.1997, 1, VU; Milaičiai, 12.07.2017, 1, VU; Pasalupis, 14.08.2011, 1 (Ф), GS; Trak: Trakai forest district, $-.07 .1965,1$, SP; Trakai, -.06.1995, 1, SP; Ukm: Vytinèlès miškas, 18.07.2004, deciduous forest, pitfall trap, 1, NN; Viln: Maišiagala (Kalniškès), 08.05.2006, 1, PI; ibidem, 21-28.06.2015, Malaise trap, 1, PI; Paberžè (Medyna), -.-.1888, 1, BH; Vilnius, city park, 26.06.1982, 1, PI; Vilnius (Fabijoniškès), 20.06.2018, 1 (Ф), AJu; (Vilnius) Verkiai, 22.06.1972, 1, VKa; ibidem, 1421.07.2003, 1, PI; KR: Pol: 2 km SE Veselovka, 09.06.1998, 1, VA; 1 km N Sosnovka, 22.06.2010, 2, VA; 2 km SE Fevral'skoe, 28.06.2020, 2 (6), VA; Zel: 3 km SW Riabinovka, 08.07.2010, 1, VA.

Published local records. LT: It is ranked as not rare and noted as distributed throughout the country by Pileckis, Monsevičius (1997); however, the actual faunistic information on the occurrence of this species is given only 
from Vilnius district (Pileckis, 1958; Ostrauskas, 2020). KR: Lentz, 1879 (Toxotus); Bercio, Folwaczny, 1979; Alekseev, Sakhnov, 2002; Alekseev, 2007.

General distribution. The species is distributed from Iberia and Great Britain to the Chelyabinsk region and north-western Kazakhstan. Its northward distribution range reaches $60^{\circ} \mathrm{N}$ in Scandinavia and the Kirov region in European Russia. This species is known in almost all the countries of southern Europe, while its records are still absent from the southern provinces of Ukraine, the northern Caucasus, and the Astrakhan region.

Notes on biology. The species is largely polyphagous on deciduous trees, but prefers Acer, Quercus, Fagus, Ulmus, Alnus, Fraxinus, Populus, and Salix. The larvae develop underground, in dead roots; pupation occurs in the soil near the host. Adults emerge in late spring or early summer; they are diurnal and anthophilous, visiting primarily the blossom of Apiaceae and Fillipendula ulmaria. The life cycle lasts two or three years.

Local occurrence and phenology. The species is locally distributed and rare in the region, and actual records are still lacking from the southern part of LT. It is recorded from 23 districts (Fig. 8); the maximum of recorded adults was in June, the earliest record on 08 May, the latest on 14 August.

Comments. This species is possibly endangered in $\mathrm{KR}$ and requires protection. IUCN Red List Category (EU) - LC.

\section{Tribe Rhamnusiini Danilevsky in Althoff, Danilevsky 1997}

Genus Rhamnusium Latreille, 1829

R. bicolor bicolor (Schrank, 1781) = Rh. gracilicorne Théry, 1895

Examined actual data. LT: Bir: Biržų giria, 15.06.1965, 1, SP; Kau: Kaunas, 07.05.1937, 1, PRé; Kaunas (Panemunè), 24.06.1980, 1. AM; Dubravos miškas, 11.06.1956, 2, SP; ibidem, 25.06.1958, 2, SP; Ras: Plembergas, 08.06.2019, 1 (C), MBr; Šak: Žemoji Panemunè, 14.06.1992, on birch trunk, 1, RF; Šiau: Slydžiai, 16.05.2013, in decaying wood of Acer platanoides, 3 larvae, VT;
Šilu: Šilutè, 15.07.1964, 1, SP; Trak: Kariotiškès, 18.06.1956, 1, SP; Viln: Vilnius, 27.05.1983, 1, Z. Pajaujyte. KR: Gur: Kaliningrad, 04.06.2018, 1, VA; Prav: 3 km SW Pravdinsk, 08.06.2019, on Populus nigra, 1, VA; Bagr: 4 km W Kamenka, 15.06.2019, in old Acer platanoides, 1, VA.

Published local records. LT: This species was ranked as rare and distributed throughout the country, excluding the coast of the Baltic Sea and south-western regions by Pileckis, Monsevičius (1997). The actual faunistic information is given on the occurrence of this species in Alytus (Zajančkauskas, Pileckis, 1968), Rokiškis (Ferenca, 2006), Ukmergè (Stanionis, Petrikas, 2011), and Vilnius (Zawadzki, 1937; Staniulisówna, 1939) districts. KR: Lentz, 1879 (salicis Fabr.); Bercio, Folwaczny, 1979; Alekseev, 2007.

General distribution. Nominative subspecies is widely distributed in western Europe from northern Spain to the eastern Baltic region; however, the rest of the subspecies are distributed in the eastern part of Europe to the Urals; southwards, to Greece, Turkey, Syria, northern Iran, Caucasus, Transcaucasia, the north-western part of Kazakhstan, and the Asian part of the Orenburg region (Danilevsky, 2012). The northern border of the distribution range reaches southern Finland, Moscow region, and Tatarstan.

Notes on biology. This species is polyphagous on various deciduous trees: Populus, Salix, Aesculus, Acer, Tilia, Platanus, Juglans, Quercus, Prunus, and Ulmus. Larvae develop in the dead parts of living trees, usually in the places between dead and still living tissues, over a period of three years. Pupation takes place in wood in spring. Adults emerge in May-June and are predominantly active at night. They usually crawl on the trunks of host plants, extremely rarely could be found on blossoms.

Local occurrence and phenology. Due to their cryptic lifestyle, adults are rarely observed; the species seems to be locally distributed and rare; recorded from 14 districts (Fig. 8); the maximum of recorded adults was in June, the earliest record on 03 May, the latest on 21 August. 
Comments. In the Lithuanian fauna, the presence of two valid taxa in species-level $R h$. virgo (Voet) $=R h$. bicolor (Schrnk.) and Rh. gracilicorne Thery was noted by Pileckis, Monsevičius (1997). At present, the name $R h$. gracilicornis is considered a synonym of Rh. bicolor (Danilevsky, 2019). The adults of this species are very variable by the colouration of elytra, the shapes of temples, lateral prothoracic tubercules, and abdominal sternites (Danilevsky, 2012); therefore, intraspecific taxonomy remains problematic. Currently, ten regional subspecies are designated (Danilevsky, 2019), but it is still unclear which particular subspecies occurs in the eastern Baltic region. In this area, the distribution ranges of two subspecies, Rh. bicolor bicolor and Rh. bicolor constans, possibly overlap (Danilevsky, 2014). Both of these subspecies are noted for Estonia and Finland, while only $R h . b$. constans is noted for Latvia and Lithuania. Following Danilevsky (2012), the main characteristic of $R h . b$. constans is a very high level of the sexual dimorphism of colouration: the domination of dorsally red-coloured males and bicoloured females. We have examined a total of four males and nine females but did not found a "very high level" of colour dimorphism. Only one male had red elytra and three had the same colouration as females. Based on available local material, we cannot confirm the presence of $R h$. $b$. constans in the fauna of the south-eastern Baltic region and, consequently, we suggest the presence of nominative subspecies only. Possibly it is an endangered species in the region and requires protection. IUCN Red List Category (EU) - VU.

\section{DISCUSSION}

More than 3,000 actual records (2,662 in LT and 354 in KR) of Lepturinae dating from 1888 were analysed altogether, and the reliable presence of 38 ( 29 for KR and 37 for LT) species in the fauna of the region were confirmed. The presence of eight species - Alosterna ingrica, Brachyta interrogationis, Euracmaeops marginatus, Euracmaeops septentrionis, Gnathacmaeops pratensis,
Pachytodes erraticus, Rhagium bifasciatum, and Stictoleptura variicornis - previously mentioned in the literature remains dubious in the region due to the lack of voucher material. However, the presence of these species, in addition to another five species - Euracmaeops angusticollis, Grammoptera u. ustulata, Nivelia sanguinosa, Pedostrangalia revestita, and Stictoleptura s. scutellata, which are distributed in neighbouring countries (Table) - is more or less possible in the region. But it should be noted that some of these species are known only from old data and lack voucher material from the neighbouring countries, too.

Currently, we do not have enough evidence to include Cortodera humeralis, Rhagium bifasciatum, and Stenocorus q. quercus in the group of possible species of the local fauna. However, despite our belief that some additional species could be disclosed in the region in the future, we would like to note that some of them - Euracmaeops smaragdulus, Rhagium sycopantha, Leptura thorasica, Lepturalia nigripes, and Lepturobosca virens - can be extremely rare or even extinct in the region. These species were not recorded in the region during the last 50 years. It is quite possible that populations of these species declined due to the loss of suitable habitats. Also, 18 more species that are locally distributed and rare in at least one of the areas (LT or KR) were designated: Anoplodera r. rufipes, Anoplodera sexguttata, Cortodera femorata, Etorofus pubescens, Euracmaeops smaragdulus, Evodinellus borealis, Grammoptera abdominalis, Judolia sexmaculata, Leptura aethiops, Oxymirus cursor, Pachyta l. lamed, Pachyta quadrimaculata, Pidonia lurida, Rhamnusium b. bicolor, Rutpela maculata, Stenocorus meridianus, Stenurella $b$. bifasciata, and Stenurella n. nigra. Further study of these species could help to predict the factors causing the decline of their populations in the region.

The studied territory belongs to the deciduous-coniferous zone. The broad-leaved and coniferous tree stands inhabited by the nemoral and boreal elements are intermixed here in various degrees depending on humidity, soil, continentality index, and landscape 
Table. List of Lepturinae (Coleoptera: Cerambycidae) species and characteristics of its distribution in the south-eastern Baltic region and neighbouring regions according to: Dunskis, 2019; Mapa Bioróżnorodności, 2020; Plewa (personal communication); Aleksandrowicz et al., 1996; Pisanenko (personal communication); Bíly, Mehl, 1989. PL - northeastern (southwards to $52^{\circ} \mathrm{N}$, westwards to $18^{\circ} \mathrm{E}$ ) part of Poland, BY - western (southwards to $52^{\circ} \mathrm{N}$, eastwards to $30^{\circ} \mathrm{E}$ ) part of Belarus, $\mathrm{LV}$ - Latvia, SV - southern (northwards to $60^{\circ} \mathrm{N}$ ) part of Sweden, KR - Kaliningrad Region, LT - Lithuania; status of distribution and rarity: $\mathbf{w}$-a - widely distributed, abundant; 1 -a - locally distributed, abundant; $1-r$ - localy distributed, rare; (?) - unconfirmed data; (-) - absent in the territory; $\frac{\underline{\underline{3}}}{\overline{3}}$ - possible in the territory. Horotypes are designated following Gorodkov $(1984,1992)$ and partly modified by Tatarinova et al. 2016: Sibero-European (SIE), Sibero-Europeo-Far Eastern (SIE-FE), Sibero-European-Western-Central Asiatic (SIE-WCA), TransEurasian - Temperate (TEA-T), TransEurasian-Boreo-Mountan (TEABM), Caucaso-Europeo-Siberian (CE-SI), Caucaso European-Western-Central Asiatic (CE-WCA), Kazakhstano-European (KAE), European (EUR), West Palaearctic (WPA), Transpalaearctic (PAL)

\begin{tabular}{|c|c|c|c|c|c|c|c|c|}
\hline \multirow[t]{2}{*}{ No. } & \multirow[t]{2}{*}{ Species } & \multicolumn{4}{|c|}{$\begin{array}{l}\text { Distribution in neigh- } \\
\text { bouring regions }\end{array}$} & \multicolumn{2}{|c|}{$\begin{array}{l}\text { Status of distri- } \\
\text { bution and rarity }\end{array}$} & \multirow[t]{2}{*}{$\begin{array}{r}\text { Horotypes } \\
\text { (for species) }\end{array}$} \\
\hline & & $\mathrm{PL}$ & BY & LV & SV & KR & LT & \\
\hline 1. & Alosterna ingrica (Baeckmann) & + & + & + & - & $\frac{\underline{\underline{\underline{\underline{\underline{T}}}}}}{\overline{\overline{\mathrm{j}}}}$ & $?$ & SIE \\
\hline 2. & Alosterna t. tabacicolor (DeGeer) & + & + & + & + & $\mathrm{w}-\mathrm{a}$ & $\mathrm{w}-\mathrm{a}$ & TEA-T \\
\hline 3. & Anastrangalia d. reyi (Heyden) & + & + & + & + & $\mathrm{w}-\mathrm{a}$ & $\mathrm{w}-\mathrm{a}$ & TEA-T \\
\hline 4. & Anastrangalia sanguinolenta (L.) & + & + & + & + & $1-\mathrm{a}$ & $\mathrm{w}-\mathrm{a}$ & CE-SI \\
\hline 5. & Anoplodera r. rufipes (Schaller) & + & + & $?$ & + & $1-r$ & $1-r$ & CE-WCA \\
\hline 6. & Anoplodera sexguttata (F.) & + & + & + & + & $\mathrm{w}-\mathrm{a}$ & $1-r$ & WPA \\
\hline 7. & Brachyta i. russica (Herbst) & $?$ & + & + & + & $?$ & $?$ & TEA-BM \\
\hline 8. & Carilia v.virginea (L.) & + & + & + & + & $\mathrm{w}-\mathrm{a}$ & $\mathrm{w}-\mathrm{a}$ & SIE -FE \\
\hline 9. & Cortodera femorata (F.) & + & + & + & + & $1-r$ & $1-r$ & SIE \\
\hline 10. & Cortodera h. humeralis (Schaller) & + & - & - & - & - & - & EUR \\
\hline 11. & Dinoptera collaris (L.) & + & + & + & + & $\mathrm{w}-\mathrm{a}$ & $\mathrm{w}-\mathrm{a}$ & SIE-WCA \\
\hline 12. & Etorofus pubescens (F.) & + & + & + & + & $\frac{\underline{\underline{\underline{\underline{b}}}}}{\overline{\bar{J}}}$ & $1-r$ & EUR \\
\hline 13. & Euracmaeops angusticollis (Gebler) & + & + & - & - & $\frac{\underline{\underline{\underline{\underline{\underline{b}}}}}}{\overline{\bar{T}}}$ & $\frac{\underline{\underline{\underline{\underline{\underline{t}}}}}}{\overline{\bar{j}}}$ & SIE-FE \\
\hline 14. & Euracmaeops marginatus (F.) & + & + & + & + & $\frac{\underline{\underline{\underline{\underline{i}}}}}{\overline{\bar{n}}}$ & $?$ & SIE-FE \\
\hline 15. & Euracmaeops septentrionis (Thomson) & + & $?$ & - & + & $\frac{\underline{\underline{\underline{\underline{i}}}}}{\overline{\bar{b}}}$ & $\frac{\underline{\underline{\underline{\underline{i}}}}}{\overline{\bar{b}}}$ & TEA-BM \\
\hline 16. & Euracmaeops smaragdulus (F.) & - & $?$ & - & - & $\frac{\underline{\underline{\underline{\underline{i}}}}}{\overline{\bar{T}}}$ & $1-\mathrm{r}$ & TEA-BM \\
\hline 17. & Evodinellus borealis (Gyll.) & + & + & + & + & $\frac{\underline{\underline{\underline{\underline{i}}}}}{\overline{\bar{T}}}$ & $1-\mathrm{r}$ & TEA-BM \\
\hline 18. & Gnathacmaeops pratensis (Laichart.) & - & + & + & + & $\frac{\underline{\underline{\underline{\underline{\underline{j}}}}}}{\overline{\bar{T}}}$ & $?$ & TEA-BM \\
\hline 19. & Grammoptera abdominalis (Step.) & + & $?$ & - & + & $1-r$ & $1-r$ & SIE-WCA \\
\hline 20. & Grammoptera r. ruficornis (F.) & + & + & + & + & $\mathrm{w}-\mathrm{a}$ & $\mathrm{w}-\mathrm{a}$ & EUR \\
\hline 21. & Grammoptera u. ustulata (Schaller) & + & - & + & + & $\frac{\underline{\underline{\underline{\underline{i}}}}}{\overline{\bar{n}}}$ & $\stackrel{\underline{\underline{\underline{\underline{\underline{t}}}}}}{\overline{\bar{y}}}$ & EUR \\
\hline 22. & Judolia sexmaculata (L.) & + & + & + & + & $1-\mathrm{r}$ & $1-\mathrm{r}$ & KAE \\
\hline 23. & Leptura aethiops Poda von Neuhaus & + & + & + & - & $1-r$ & $1-\mathrm{a}$ & SIE-FE \\
\hline 24. & Leptura a. annularis (F.) & + & + & + & - & $\mathrm{w}-\mathrm{a}$ & $1-r$ & SIE-FE \\
\hline 25. & Leptura q. quadrifasciata (L.) & + & + & + & + & $\mathrm{w}-\mathrm{a}$ & $\mathrm{w}-\mathrm{a}$ & TEA-T \\
\hline 26. & Leptura t. thoracica Creutzer & + & + & + & - & $\frac{\underline{\underline{\underline{\underline{\underline{t}}}}}}{\overline{\bar{y}}}$ & $1-r$ & SIE-FE \\
\hline 27. & Lepturalia $n$. nigripes (DeGeer) & + & + & + & + & $\frac{\underline{\underline{\underline{\underline{i}}}}}{\overline{\bar{y}}}$ & $1-r$ & SIE-FE \\
\hline 28. & Lepturobosca virens (L.) & + & + & + & + & $\frac{\underline{\underline{\underline{\underline{\bar{t}}}}}}{\overline{\bar{T}}}$ & $1-r$ & TEA-BM \\
\hline
\end{tabular}


A survey of Lepturinae Latreille, 1802 (Coleoptera: Cerambycidae) of the south-eastern Baltic region... 225

Table. (Continued)

\begin{tabular}{|c|c|c|c|c|c|c|c|c|}
\hline \multirow[t]{2}{*}{ No. } & \multirow[t]{2}{*}{ Species } & \multicolumn{4}{|c|}{$\begin{array}{l}\text { Distribution in neigh- } \\
\text { bouring regions }\end{array}$} & \multicolumn{2}{|c|}{$\begin{array}{l}\text { Status of distri- } \\
\text { bution and rarity }\end{array}$} & \multirow[t]{2}{*}{$\begin{array}{c}\text { Horotypes } \\
\text { (for species) }\end{array}$} \\
\hline & & $\mathrm{PL}$ & BY & LV & SV & KR & LT & \\
\hline 29. & Nivelia sanguinosa (Gyll.) & + & + & + & + & $\frac{\underline{\underline{\underline{\underline{\underline{k}}}}}}{\overline{\bar{I}}}$ & $\frac{\underline{\underline{\underline{\underline{\bar{j}}}}}}{\overline{\bar{y}}}$ & SIE-FE \\
\hline 30. & Oxymirus cursor (L.) & + & + & + & + & $1-r$ & $1-r$ & SIE \\
\hline 31. & Pachyta l. lamed (L.) & + & + & + & + & $\frac{\underline{\underline{\underline{\underline{T}}}}}{\overline{\bar{z}}}$ & $1-\mathrm{r}$ & TEA-BM \\
\hline 32. & Pachyta quadrimaculata (L.) & + & + & + & - & $1-r$ & $\mathrm{w}-\mathrm{a}$ & SIE \\
\hline 33. & Pachytodes cerambyciformis (Schrank) & + & + & $?$ & - & $\mathrm{w}-\mathrm{a}$ & $1-\mathrm{a}$ & EUR \\
\hline 34. & Pachytodes erraticus (Dalman) & $?$ & $?$ & - & - & $?$ & $\frac{\underline{\underline{\underline{\underline{j}}}}}{\overline{\bar{l}}}$ & SIE-WCA \\
\hline 35. & Pedostrangalia revestita (L.) & + & - & - & + & $\frac{\underline{\underline{\underline{\underline{i}}}}}{\overline{\bar{c}}}$ & $\frac{\underline{\underline{\underline{\underline{i}}}}}{\overline{\bar{c}}}$ & EUR \\
\hline 36. & Pidonia lurida (F.) & - & - & + & - & $\frac{\underline{\underline{\underline{\underline{i}}}}}{\overline{\bar{y}}}$ & $1-\mathrm{r}$ & EUR \\
\hline 37. & Pseudovadonia l. bicarinata (N. Arnol) & + & + & + & + & $\mathrm{w}-\mathrm{a}$ & $\mathrm{w}-\mathrm{a}$ & SIE-FE \\
\hline 38. & Rhagium bifasciatum $\mathrm{F}$. & - & - & - & - & - & - & CE-WCA \\
\hline 39. & Rhagium i. inquisitor (L.) & + & + & + & + & $\mathrm{w}-\mathrm{a}$ & $\mathrm{w}-\mathrm{a}$ & PAL \\
\hline 40. & Rhagium mordax (DeGeer) & + & + & + & + & $\mathrm{w}-\mathrm{a}$ & $\mathrm{w}-\mathrm{a}$ & SIE \\
\hline 41. & Rhagium sycophanta (Schrank) & + & + & + & + & $\frac{\underline{\underline{\underline{\underline{i}}}}}{\overline{\bar{y}}}$ & $1-\mathrm{r}$ & EUR \\
\hline 42. & Rhamnusium b. bicolor (Schrank) & + & + & + & - & $1-\mathrm{r}$ & $1-\mathrm{r}$ & CE-WCA \\
\hline 43. & Rutpela maculata (Poda von Neuhaus) & + & + & + & + & $1-r$ & $?$ & CE-WCA \\
\hline 44. & Stenocorus meridianus (L.) & + & + & + & + & $1-r$ & $1-\mathrm{a}$ & SIE \\
\hline 45. & Stenocorus q. quercus (Götz) & + & $?$ & - & - & - & - & SIE \\
\hline 46. & Stenurella b. bifasciata (Müller) & + & + & + & - & $1-r$ & $\mathrm{w}-\mathrm{a}$ & SIE-WCA \\
\hline 47. & Stenurella m. melanura (L.) & + & + & + & + & $\mathrm{w}-\mathrm{a}$ & $\mathrm{w}-\mathrm{a}$ & SIE-FE \\
\hline 48. & Stenurella n. nigra (L.) & + & + & + & + & $\mathrm{w}-\mathrm{a}$ & $1-\mathrm{r}$ & CE-WCA \\
\hline 49. & Stictoleptura maculicornis (DeGeer) & + & + & + & + & $\mathrm{w}-\mathrm{a}$ & $\mathrm{w}-\mathrm{a}$ & EUR \\
\hline 50. & Stictoleptura r. rubra (L.) & + & + & + & + & $\mathrm{w}-\mathrm{a}$ & $\mathrm{w}-\mathrm{a}$ & SIE \\
\hline 51. & Stictoleptura s. scutellata (F.) & + & $?$ & + & + & $\frac{\underline{\underline{\underline{\underline{\underline{e}}}}}}{\overline{\overline{\mathrm{c}}}}$ & $\frac{\underline{\underline{\underline{\underline{i}}}}}{\overline{\bar{j}}}$ & EUR \\
\hline 52. & Stictoleptura v. variicornis (Dalman) & + & + & + & - & $?$ & $?$ & SIE-FE \\
\hline \multirow[t]{2}{*}{53.} & Strangalia attenuata (L.) & + & + & + & + & $\mathrm{w}-\mathrm{a}$ & $\mathrm{w}-\mathrm{a}$ & TEA-T \\
\hline & & 47 & 42 & 42 & 37 & 29 & 37 & \\
\hline
\end{tabular}

characteristics. The territory of the region is often designated as the transitional area between northern and central or between eastern and western European faunas by zoogeographical mapping. We noted how this impacted the spectrum of horotypes of Lepturinae in the studied region. It suggests that the formation of the composition of Lepturinae species in the region has been strongly affected by climatic oscillations during the last postglacial period and possible recolonization of the region by the lepturins from different refugia. This version of general formation of the Euro- pean fauna was well explained for by Schmitt, Varga (2012). It is interesting to note that some species occurring in the region confirm this point of view. For example, Euracmaeops smaragdulus, Evodinellus borealis, Lepturobosca virens, and Pachyta l. lamed represent BorealMountain fauna in the region, while Grammoptera abdominalis, Rhagium sycopantha, and Rutpela maculata can be considered as representatives of the Central-European fauna; $\mathrm{Pi}$ donia lurida represent the Western-European fauna, and Leptura thorasica is an example of the Eastern-European fauna. 
Keeping in mind the high similarity of the geographic location, climatic conditions, and floral composition of LT and KR, it is unexpected that we found here slightly different Lepturinae fauna. Of course, it could have been due to a different research history of this group of beetles in the territories. However, a higher abundance of such species as Anoplodera sexguttata, Rutpela maculata, Pachytodes cerabyciformis, and Stenurella $n$. nigra should suggest the presence of more suitable habitats for these species in KR or some peculiarities of its distribution. Moreover, this trend seems even more convincing given the biology of these species. They all are closely associated with deciduous trees. Distribution maps of these species (Fig. 3, $5,6)$ well reflect the distribution of broadleaf forests in the studied region. These species are probably also more dependent on the Atlanticinfluenced climate.

The current "absence" of a species like Evodinellus borealis or Pachyta lamed in KR is probably due to the lack of systemic and careful collecting activity in the eastern and south-eastern parts of KR during the appropriate time of year. For example, both species are reported from the Augustów Forest in Poland (Gutowski, 1995; Gutowski et al., 2011), situated in the nearest vicinity of the southern boundary of KR.

\section{ACKNOWLEDGEMENTS}

We are grateful to Dr Mikhail L. Danilevsky, Dr Dmitry Telnov, Dr Francesco Vitali, Prof. Jerzy M. Gutowski, Dr Radosław Plewa, Dr Aleksandr D. Pisanenko, Ilmar Süda, MSc, and Mr Jacek Kurszawa for constructive discussions, assistance with identifications of beetles, literature, and useful comments on this study. We would like to thank Dr Pivilas Ivinskis, Dr Andrius Petrašiūnas, Mr Rimantas Butvila, and Mr Aleksandras Meržijevskis, who loaned their material for examination. We are grateful to all the collectors and observers who shared their material and observations for analysis. We also thank $\mathrm{Mr}$ Gintautas Steiblys for his assistance in preparing some of the figures. The authors are sincerely grateful to Maximilan and Mark Pankowski
(Rockville, Maryland, USA) for linguistic suggestions on an early version of the manuscript, and to the reviewers for their valuable suggestions that improved our manuscript.

Received 26 September 2020

Accepted 26 October 2020

\section{References}

1. Aleksandrowicz OR, Lopatin IK, Pisanenko AD, Tsinkewich VA, Snitko SM. A catalogue of Coleoptera (Insecta) of Belarus. Minsk: Fund of Fundamental Investigations of the Republic of Belarus: Minsk; 1996. p. 103.

2. Aleksandrowicz O, Tsinkewich V. Aktualny stan poznania chrzązczy (Insecta: Coleoptera) białoruskiej szęści Puszczy Białowieskiej. In: Krzyściak-Kosińska R, editor. Nauka - Przyroda - Człowiek. Konferencja Jubileuszowa z okazji 85-lecia Białowieskiego Parku Narodowego. 9-10 czerwca 2006; Białowieża, Poland; 2006. p. 83-103. Polish.

3. Alekseev VI, Bukejs A. Contributions to the knowledge of beetles (Insecta: Coleoptera) in the Kaliningrad region. 4. Zool Ecol. 2014; 24(1): 26-32.

4. Alekseev VI, Bukejs A, Drotikova AM, Rozhina VI. Contributions to the knowledge of beetles (Insecta: Coleoptera) in the Kaliningrad region. 5. Zool Ecol. 2015; 25(3): 247-56.

5. Alekseev VI, Bukejs A. Contributions to the knowledge of beetles (Insecta: Coleoptera) in the Kaliningrad Region. 6. Zool Ecol. 2017; 27(3-4): 261-8.

6. Alekseev VI, Sakhnov NI. Fauna i nekotorye ekologicheskie osobennosti zhukovdrovosekov (Coleoptera: Cerambycidae) Kaliningradskoi oblasti. In: Bryushinkin VN, Dedkov VP, Beloglazov SM, Funtikov VA, Rybakova GA, editors. Problemy biologicheskikh i khimicheskikh nauk: materyaly postojannyh nauchnyh seminarov. Kaliningrad: Kaliningradskij Gosudarstvennyj universitet; 2002. p. 6-10. Russian. 
7. Alekseev VI. Materialy po faune zhestkokrylykh xilo-micetobiontov (Coleoptera) Kurshskoi kosy. In: Rylkov OV, Zhukovskaja IP, editors. Problemy izychenija i ohrany prirodnogo i kulturnogo parka "Kurshskaia kosa" Vypusk 4. Kaliningrad: Russkij Gosudarstvennyj universitet imeni I. Kanta; 2006. p. 28-47. Russian.

8. Alekseev VI. Longhorn beetles (Coleoptera: Cerambycidae) of Kaliningrad region. Acta Biologica Universitatis Daugavpiliensis. 2007; 7(1): 37-62.

9. Alekseev VI, Bukejs A. Contributions to the knowledge of beetles (Insecta: Coleoptera) in the Kaliningrad region. 2. Balt J Coleopterol. 2011; 11(2): 209-31.

10. Alkan H, Eroğlu M. A contribution to the knowledge of Cerambycidae (Insecta: Coleoptera) species in the Eastern Black Sea Region in Turkey. Turk Entomol Derg-Tu. 2001; 25(4): 243-55.

11. Barševskis A, Savenkovs N. Contribution to the knowledge of long-horned beetles ( $\mathrm{Co}-$ leoptera: Cerambycidae) in Latvia. Balt J Coleopterol. 2013; 13(2): 91-102.

12. Barševskis A, Lecka K. To the knowledge of longhorn beetles (Coleoptera: Cerambycidae) fauna of Latvia. Acta Biologica Universitatis Daugavpiliensis. 2019; 19(2): 279-85.

13. Bartenev AF. A review of the long-horned beetles' species (Coleoptera: Cerambycidae) of the fauna Ukraine. The Kharkov Entomological Society Gazette. 2004; 11(1-2): 24-43.

14. Bartenev AF. Zhuki-usachi levoberezhnoi Ukrainy i Kryma. Kharkov: Kharkovskii Nacionalnyi Universitet imeni V. N. Karazina; 2009. p. 418. Russian.

15. Belova YuN, Dolganova MN, Kolesova NS, Shabunov AA, Filonenko IV. Diversity of insects of the Vologda region. Vologda: Vologda State Pedagogical University, Department of Zoology and Ecology; 2008. p. 368. Russian.

16. Benyahia Y, Brustel H, El Antry S, Courtin O, Maatouf N, Vallandares L, Rohi L. Preliminary list of Coleoptera heritage species of the Talassemtane National Park, Morocco. Journal of Insect Biodiversity. 2016; 4(13): 1-30.

17. Bercio H, Folwaczny B. Verzeichnis der Käfer Preussens. Fulda: Parzeller \& Co; 1979. p. 369. German.

18. Bíly B, Mehl O. Longhorn Beetles (Coleoptera, Cerambycidae) of Fennoscandia and Denmark. (Fauna Entomologica Scandinavica 22). Leiden, New York, København, Köln: E. J. Brill/ Scandinavian Science Press Ltd.; 1989. p. 203.

19. Bousquet Y. Checklist of beetles of Canada and Alaska. Ottawa: Canada Communication Group - Publishing; 1991. p. 430.

20. Bousquet Y, Heffern DJ, Bouchard P, Nearns EH. Catalogue of family-group names in Cerambycidae (Coleoptera). Zootaxa. 2009; 2321: 1-80.

21. Brelih S, Drovenik B, Pirnat A. Material for beetle fauna (Coleoptera) of Slovenia 2nd contribution: Polyphaga: Chrysomeloidea (=Phytophaga): Cerambycidae. Scopolia. 2006; 58 : $1-442$.

22. Burakowski B. Immature stages and bionomics of Vadonia livida (F.) (Coleoptera, Cerambycidae). Annales Zoologici. 1979; 35(2): $25-42$.

23. Burakowski B, Mroczkowski M, Stefańska J. Katalog fauny Polski, Tom. 15: Chrzązzcze - Coleoptera. Cerambycidae i Bruchidae. Warzawa: Państwowe wydawnictwo naukowe; 1990. p. 312. Polish.

24. Butvila R, Dūda J, Ramonas V. Duomenys apie retas vabzdžių rūšis. Raudoni lapai. 2007; 9: 37-40. Lithuanian.

25. Cálix M, Alexander KNA, Nieto A, Dodelin B, Soldati F, Telnov D, Vazquez-Albalate X, Aleksandrowicz $\mathrm{O}$, Audisio P, Istrate $\mathrm{P}$, Jansson $\mathrm{N}$, Legakis A, Liberto A, Makris C, Merkl O, Mugerwa Pettersson R, Schlaghamersky J, Bologna MA, Brustel H, Buse J, Novák V, Purchart L. European Red List of Saproxylic Beetles. Brussels: IUCN; 2018. Available at: https://portals.iucn.org/library/node/47296 
26. Cherepanov AI. Usachi Severnoi Azii, tom 1 (Prioninae, Disteniinae, Lepturinae, Aseminae). Novosibirsk: Izdatelsvo "Nauka"; 1979. p. 700. (Russian).

27. Dascălu M-M, Sama G, Ramel G. A report on the Cerambycidae species from the Lake Kerkini National Park, Northern Greece. Analele Ştiinţifice ale Universităţii "Alexandru Ioan Cuza" din Iaşi, s. Biologie animal. 2012; 58 : 65-76.

28. Danilevsky ML. A. checklist of the longicornbeetles (Coleoptera: Cerambycidae) of Moscow region. Russ Entomol J. 2005; 15(1): 43-51.

29. Danilevsky ML. A contribution to the revision of the genus Rhamnusium Lattreille, 1829 (Coleoptera: Cerambycidae). Studies and Reports Taxonomical Series. 2012; 8(1-2): 43-65.

30. Danilevsky ML. Zhuki - usachi (Coleoptera, Cerambycoidea) Rossii i sosednikh stran Chast' 1. Moscow: HSC; 2014. p. 522. Russian.

31. Danilevsky ML. Catalogue of Palaearctic Cerambycoidea. 2019. Available at: https://www. zin.ru/animalia/coleoptera/rus/danlists.htm

32. Danilevsky ML, Miroshnikov AI. Zhukidrovoseki Kavkaza (Coleoptera, Cerambycidae). Opredelitel'. Krasnodar: Kubanskii ordena trudovogo krasnogo znameni selskohoziaistvennyi institut, Krasnodarskaia kraevaja stantsiia zaschity rastenii; 1985. p. 419. Russian.

33. Danilevsky ML, Peks H. Subspecific structure of Brachyta interrogationis (Linnaeus, 1758) (Coleoptera: Cerambycidae) in West Europe with a description of a new subspecies. Humanity space International almanac. 2016; 5(2): 178-82.

34. Danilevsky ML, Smetana A. Cerambycidae taxa from Russia and countries of former Soviet Union and Mongolia. Subfamily Lepturinae. In: Löbl I, Smetana A, editors. Catalogue of Palaearctic Coleoptera, 6. Senstrup: Apollo Books; 2010. p. 95-241.

35. Demelt C. Die Pachyta lamed L. und ihre aberrativen Formen aus Kärnten. Carinthia. 1948; 2(137-138): 152-4. German.
36. Demelt v C. Bockkäfer oder Cerambycidae. 1: Biologie mitteleuropäischer Bockkäfer (Col. Cerambycidae) unter besonderer Berücksichtigung der Larven. In: Dahl M, Peus F, editors. Die Tierwelt Deutschlands und der angrenzenden Meeresteile, 52. Jena: Gustav Fisher; 1966. p. 1-115. German.

37. Dedyukhin SV, Nikitskij NB, Semenov VB. Checklist of beetles (Insecta, Coleoptera) of Udmurtia. Euroasian Entomological Journal. 2005; 4(4): 293-315.

38. Dodelin B, Alexander K, Aleksandrowicz O, Audisio P, Istrate P. Pidonia lurida. The IUCN Red List of Threatened Species. 2017: Available at: http://dx.doi.org/10.2305/IUCN.UK. 20173.RLTS.T86848967A87311452.en.

39. Duff AG. Beetles of Britain and Ireland, Volume 4. Cerambycidae to Curculionidae. Norfolk: AG Duff Publishing; 2016. p. 623.

40. Dunskis A, Barševskis A. Catalogue of longhorn beetles (Coleoptera: Cerambycidae) of Latvia. Acta Biologica Universitatis Daugavpiliensis. 2018; 18(2): 165-98.

41. Dunskis A. Koksngraužu dzimtas (Coleoptera: Cerambycidae) fauna un izplatība Latvijā. Koksngraužu sugu atradṇu katalogs [bakalaura darba pielikums]. Daugavpils: Daugavpils University; 2019. p. 196. Latvian.

42. Dutrillaux AM, Dutrillaux B. Loss of Y chromosome may be a synapomorphy of the tribe Lepturini (Coleoptera: Cerambycidae: Lepturinae). Eur J Entomol. 2018; 115: 45-52.

43. Eckelt A, Müller J, Bense H, Bussler H, Chittaro Y, Cizek L, Frei A, Holzer E, Kadej M, Kahlen M, Köhler F, Möller G, Mühle H, Sanchez A, Schaffrath U, Schmidl J, Smolis A, Szallies A, Németh T, Wurst C, Thorn S, Christensen RHB, Seibold S. "Primeval forest relict beetles" of Central Europe: a set of 168 umbrella species for the protection of primeval forest remnants. J Insect Conserv. 2018; 22: 15-28. doi: https:// doi.org.10.1007/s10841-017-0028-6

44. Egorov LV. Novye i redkie dlia fauny Chuvashii vidy zhestkokrylykh nasekomykh 
(Insecta: Coleoptera). Vestnik Chyvashskogo Gosudarstvennogo pedagogicheskogo universiteta im. I. Ja. Jakovleva. 2002; 8(32): 34-42. Russian.

45. Ehnström B, Axelsson R. Insekts gnag i bark och ved. Uppsala: ArtDatabanken, SLU; 2002. p. 512. Swedish.

46. Ferenca R, Ivinskis P, Meržijevskis A. New and rare Coleoptera species in Lithuania. Ekologija. 2002; 3: 25-31.

47. Ferenca R. Retos ir naujos Lietuvos entomofaunos vabalų (Coleoptera) rūšys, rastos 1997-2002 metais. New and rare for Lithuania insect species. 2003; 15: 32-36. Lithuanian.

48. Ferenca R. A. Palionio vabalų rinkiniai. In: Ivinskis P, Rimšaite J, compilers. Entomologas Alfonsas Palionis (1905-1957). Vilnius: Vilniaus Universiteto, Ekologijos institutas; 2006. p. 162-216. Lithuanian.

49. Ferenca R, Ivinskis P, Tamutis V. New and rare for Lithiuania species of beetles (Coleoptera). New and rare for Lithuania insect species. 2006; 17: 11-21.

50. Filimonov RV, Udalov SG. 2002. Zhuki-usachi Leningradskoi oblasti. Atlas-opredelitel'. SanktPetersburg: Petroglif; 2020. p. 80. Russian.

51. Gailis J, Vilks K. New data on rare beetles (Insecta, Coleoptera) in Latvia. Latvijas Entomologs. 2001; 38: 52-55.

52. Gedminas A. The beetles living in cutting residues. In: Sklodowski J, Huruk S, Barševskis A, Tarasiuk S, editors. Protection of Coleoptera in the Baltic Sea Region. Warsaw: Warsaw Agricultural University Press; 2005. p. 171-7.

53. Georgiev G, Gjonov I, Sakalian V. New records of longhorn beetles (Coleoptera: Cerambycidae) in Strandzha Mountain. J Entomol Res Soc. 2015; 17(2): 73-88.

54. Gessitt JL. Longicorn beetles of China. Longicornia. 1951; 2: 1-667.

55. Gobbi M, Priore C, Tattoni C, Lencioni V. Suprising longhorned beetle (Coleoptera, Cerambycidae) richness along an Italian alpine valley. ZooKeys. 2012; 208: 27-39.
56. Gorski P, Tatur-Ditkowski J. Longhorn beetles (Coleoptera: Cerambycidae) of central Mozovia, Poland. Balt J Coleopterol. 2015; 15(2): 107-27.

57. Gutowski JM. Acmaeops angusticollis (Gebler, 1833) (Coleoptera, Cerambycidae) w Polsce. Polskie Pismo Entomologiczne. 1988; 58: 4936. Polish.

58. Gutowski JM, Karaš M. Evodinus borealis (Gyllenhall, 1827) (Coleoptera, Cerambycidae) w Polce. Wiadomośc Entomologczne. 1991; 10(4): 221-6. Polish.

59. Gutowski JM. Kózkowate (Coleoptera: Cerambycidae) wschodniej części Polski [praca habilitasyjna]. In Szujecka G, editor. Prace Instytutu Badawczego Leśnictwa, seria A., 811. Warszawa: Instytut Badawczego Leśnictwa; 1995. p. 1-190. Polish.

60. Gutowski JM, Zieliński S, Biwo T. Longhorn beetles (Coleoptera: Cerambycidae) of Romincka Forest. Opole Scientific Society Nature Journal. 2011; 4: 145-71.

61. Hjälten J, Hägglund R, Lötroth T, Roberge J-M, Dynesius M, Olsson J. Forest restoration by burning and gap cutting of voluntary set-aside yield distinct immediate effects on saproxylic beetles. Biodivers Conserv. 2017; 26: 1623-40.

62. Heffern DJ. Insects of western north America 1. Survey of the Cerambycidae (Coleoptera), or Longhorned beetles, of Colorado. Houston: C.P. Gillette Museum of Arthriopod Diversity, Department of Bioagricultural Sciences and Pest Management Colorado State University; 1998. p. 32.

63. Heyrovský L, Sláma G. Tesaríkoviti - Coleoptera, Cerambycidae. Zlín: Kabourek; 1992. p. 367. Czech.

64. Ilić N, Curčić S. A checklist of longhorn beetles (Coleoptera: Cerambycidae) of Serbia. Zootaxa. 2015; 4026(1): 1-97.

65. Inokaitis V. Naujos ir retos Lietuvos entomofaunos vabalų (Coleoptera) rūšys, aptiktos 2000-2003 metais. New and rare for Lithuania insect species. 2004; 16: 7-10. Lithuanian. 
66. Inokaitis V. Rare and very rare for the Lithuanian fauna Coleoptera species found in 2004-2009. New and rare for Lithuania insect species. 2009; 21: 40-4.

67. Ivinskis $P$, Meržijevskis A, Rimšaitė J. Data on new and rare for the Lithuanian fauna species of Coleoptera. New and rare for Lithuania insect species. 2009; 21: 45-63.

68. Jendek B, Jednek E. Analýza druhovej ochrany Coleoptera na Slovensku na základe modelovej skupiny fusáče (Coleoptera, Cerambycidae). Folia Faunistica Slovaca. 2006; 11(4): 15-28.

69. Karpiński L, Szczepański WT, Bolgdiv B, Walczak M. New data on the longhorn beetles of Mongolia with particular emphasis on the genus Eodorcadion Breuning, 1947 (Coleoptera: Cerambycidae). ZooKeys. 2018; 739: 107-50.

70. Kazyuchits AV, Pisanenko AD. Novye dlia Belorusii vidy zhukov-drovosekov (Coleoptera, Cerambycidae). Vestnik Belorusskogo gosudarstvennogo universiteta im. V. I. Lenina. Khimija, biologija, geografija. 1985; 2: 31-32. Russian.

71. Kierdorf-Traut G. Notizen zum Vorkommen der Gattungen Brachyta Fairmaire, 1864 und Evodinus LeConte, 1850 in Südtirol (Coleoptera: Cerambycidae). Gredieriana. 2007; 7: 219-32. German.

72. Kinel J. Kózki Polski (Cerambycidae Poloniae). Rozprawy i wiadomości z Museum im. Dzieduszyckich. 1917; 3: 37-101. Polish.

73. Lazarev MA. Subspecies structure of Brachyta interrogationis (Linnaeus, 1857) in European Russia (Coleoptera: Cerambycidae). Humanity Space. International Almanac. 2016; 5(2): 192-203.

74. Lentz FL. Catalog der Preussischen Käfer neu bearbeitet. Beiträge zur Naturkunde Preussens. 1879; 4: 1-64. German.

75. Linsley EG, Chemsak JA. Cerambycidae of North America. Part 6, No. 1. Taxonomy and classification of the subfamily Lepturinae. University of California Publications in Entomology. 1972; 69: 1-138.
76. Lundberg S, Gustafsson B. Catalogus coleopterorum Sueciae. Stockholm: Naturhistoriska Roksmuseet Entomologiska Föreinigen; 1995. p. 220.

77. Ljungberg H. Skalbaggar Coleoptera. In: Westling a editor. Rödlistade arter i Sverige. Uppsala: ArtDatabanken SLU; 2015. p. 119-40. Swedish.

78. Mapa Bioróżnorodności [online] Krajowa Sieć Informacji o Bioróżnorodności. Updated: 2020-10-08. Available at https://baza.biomap.pl

79. Mazurowa G, Mazur E. Sprawozdanie z wycieczki koleopterologicznej do wojewodztwa wileńskiego w lipcu 1937. Przyczynek do znajomości fauny połnocnej Polski, Sprawozdanie Komisji Fizjograficznej. 1939; 72: 463-76. Polish.

80. Mičulis A. Dažas ziṇas par koksngraužiem Jaunpiebalgas apkaimē. Latvijas Entomologs. 1986; 29: 35-7. Latvian.

81. Miländer G, Monsevičius V, Soo V. 26 species of Coleoptera new to the Lithuanian SSR, found in 1974-1983. In: Jonaitis V, editor. New and rare for the Lithuanian SSR insect species. Records and descriptions of 1984. Vilnius: Lietuvos ekologijos ir parazitologijos institutas, Lietuvos Entomologų draugija: 1984; 23-30.

82. Miłkowski M. Kózkowate Cerambycidae (Coleoptera) puszczy Kozienickiej. Kulon. 2004; 9(1): 81-116. Polish.

83. Monnerat C, Barbalat S, Lachat T, Gonseth Y. Rote Liste der Pranchtkäfer Bockkäfer, Rosenkäfer und Schröter. Gefährdete Arten der Schweiz. Bundesamt für Umwelt. Bern: Info Fauna - CSCF, Neuenburg, Eidg. Forschungsanstalt WSL, Birmensdorf. Umwelt-Vollzung Nr. 1622; 2016. p. 118. German.

84. Moretti M, De Cáceres M, Pradella C, Obrist MK, Wermelinger B, Legendre P, Duelli P. Fire-induced taxonomic and functional changes in saproxylic beetle communities in fire sensitive regions. Ecography. 2010; 33: 760-71.

85. Mpamnaras AG, Eliopoulos PA. First record of the wood-boring beetles Oxymirus cursor 
and Sinodendron cylindricum in Greece. Entomologia Hellenica. 2017; 26: 1-5.

86. Mulerčikas P, Tamutis V, Kazlauskaitè S. New data on seven protected and two rare beetle (Insecta, Coleoptera) species registered in Lithuania in 1997-2011. New and rare for Lithuania insect species. 2011; 23: 30-3.

87. Müller OF. Zologiae Danicae prodromus: seu Animalium Daniae et Norvegiae indigenarum; characteres, nomina, et synonyma imprimis popularium. Havniæ: Typis Hallageriis; 1776. p. 274. Latin.

88. Naturhistorisk Museum. [online] 2009. Toflekket bartreløper (Rhagium bifasciatum (Fabricius, 1775). Facta om naturen. 2011-09-01. Available at https://www.nhm.uio.no/fakta/ zoologi/insekter/norcol/cerambyc/R_bifasciatum.html

89. Nikitsky NB, Osipov IN, Chemeris MV, Semenov VB, Gusakov AA. Zheskokrylye - ksilobionty, mitsetobionty i plastinchatousye Prioksko-Terranskogo biosfernogo zapovednika. Sbornik trudov zoologicheskogo muzeja Moskovskogo gosudarstvennogo universiteta. 1996; 34: 1-197. Russian.

90. Ødegaard F, Andersen J, Hanssen O, Kvamme T, Olberg S. Biller Coleoptera. In Kålås JA, Viken Å, Henriksen S, Skjelseth S, editors. Norsk Rødliste for arter 2010. Tronheim: Norwegian Biodiversity Information Centre; 2010. p. 257-90. Norwegian.

91. Ösdikmen H. The longicorn beetles of Turkey (Coleoptera: Cerambycidae) Part I - Black Sea Region. Mun Ent Zool. 2007; 2(2): 179-422.

92. Ösdikmen H. A new subspecies of Pseudovadonia livida (Fabricius, 1777) from Turkey (Cerambycidae: Lepturinae). Mun Ent Zool. 2015; 10(2): 319-21.

93. Ösdikmen H, Ali MA. Four genera and species new for the fauna of Iraq with a new sibspecies, Pseudovadonia livida irakensis (Coleoptera: Cerambycidae). Mun Ent Zool. 2017; 12(2): 375-9.
94. Ostrauskas H. Naujos retų rūšių vabalų radvietès Vilniuje. Raudoni lapai. 2000; 7: 36. Lithuanian.

95. Ostrauskas H. Entologiniai tyrimai 1986-1998 metais. Vilnius: Baltijos kopija; 2020. p. 498. Lithuanian.

96. Ostrauskas H, Tamutis V. Bark and longhorn beetles (Coleoptera: Curculionidae, Scolytinae et Cerambycidae) caught by multiple funnel traps at the temporary storages of timbers and wood in Lithuania. Bal For. 2012; 18(2): 263-9.

97. Palm T. Zur Kenntnis Der Biologie von Acmaeops pratensis Laich. und der verwandten Arten. Oppuscula Entomologica. 1956; 21: 233-45. German.

98. Palm T. Die Holz- und Rinden - Käfer der nordschwedischen Laubbäume. Meddelanden Från Statens Skogsforskningsinstutut. 1959; 40(2): 1-242. German.

99. Pawlowski J. Reliktowie chrząszcze Coleoptera "Puszczy Karpackiej". Roczniki Bieszczadzkie. 2008; 16: 317-24. Polish.

100. Peña CFG, Noguera EV, de Sousa Zuzarte AJ. Nuevo catálogo de los Cerambycidae (Coleoptera) de la Península Ibèrica, islas Baleares e islas atlánticas: Canarias, Açores y Madeira. Monografías Sociedad Entomológica Aragonesa. 2007; 12: 1-211. Spanish.

101. Picard F. Faune de France 20. Coléoptères, Cerambycidae. Paris: Paul Lechevalier; 1929. p. 167. French.

102. Pileckis S. Blizgiai (Buprestidae Leach.) ir ūsuočiai (Cerambycidae Latr.) pastebèti Lietuvos TSR. Lietuvos Žemès Ūkio akademijos mokslo darbai. 1958; 4: 175-81. Lithuanian.

103. Pileckis S. Indèlis ị Lietuvos vabalų (Coleoptera) faunos pažinimą. LŽŪA mokslo darbai. 1960; 7(3): 303-6. Lithuanian.

104. Pileckis S. Naujos vabalų (Coleoptera) rūšys Lietuvos TSR. LŽŪA mokslo darbai. 1963; 10(19): 53-64. Lithuanian. 
105. Pileckis S. Lietuvos vabalai. Vilnius: Mokslas; 1976. p. 244. Lithuanian.

106. Pileckis S, Monsevičius V. Lietuvos fauna. Vabalai. II d. Vilnius: Mokslo ir ensiklopedijų leidykla; 1997. p. 216. Lithuanian.

107. Plavilstchikov NN. Fauna SSSR. Nasekomye zhestkokrylye. T. 21. Zhuki - drovoseki (Ch. 1). Moskva-Leningrad: Izdatelstvo Akademii Nauk SSSR; 1936. p. 612. Russian.

108. Plewa R. Amaeops septentrionis (C. G. Thomson, 1866) (Coleoptera: Cerambycidae: Lepturinae) - stan poznania gatunku. Opole Scientific Society Nature Journal. 2010; 43 : 37-65. Polish.

109. Plewa R, Łoś K, Górski P. New data on the distribution, biology and behavior of some longhorn beetles (Coleoptera, Cerambycidae) from Greece. Elateridium. 2011; 5: 232-47.

110. Rassi P, Karjalainen S, Clayhills T, Helve E, Hyvärinen E, Laurinjarju E, Malmberg S, Mannerkoski I, Martikainen P, Mattila J, Muona J, Pentinsaari M, Rutanen I, Salokannel J, Siitonen J, Silfverberg H. Provincial list of Finish Coleoptera 2015. Sahlbergia, Supplement 1. 2015; 21: 1-164.

111. Rice ME, Merickel F, MacRae TC. The Longhorned beetles (Coleoptera: Cerambycidae) of Idaho. Coleopt Bull. 2017; 71(4): 667-78.

112. Rossa R, Goczal J, Pawliczek B, Ohbayashi N. Hind wing variation in Leptura annularis complex among European and Asiatic populations (Coleoptera, Cerambycidae). ZooKeys. 2017; 724: 31-42.

113. Ruchin AB, Egorov LV. Fauna of longhorn beetles (Coleoptera: Cerambycidae) of Mordovia. Russ Entomol J. 2018; 27(2): 161-77.

114. Saito S, Saito A, Kim C-G, Su Z-H, Osawa S. Phylogeny of the Leptura arcuata complex (Coleoptera: Cerambycidae) as deduced from mitochondrial ND5 gene sequences. Special bulletin of the Japanese Society of Coleopterology. 2002; 5: 381-91.
115. Sama G. Atlas of the Cerambycidae of Europe the Mediterranean Area. Volume 1: Northern, Western, Central, Eastern Europe, British Isles, Continental Europe from France (excl. Corsica) to Scandinavia and Urals. Zlín: Kabourek; 2002. p. 173.

116. Sama G, Löbl I. Cerambycidae. In: Löbl I, Smetana A, editors. Catalogue of Palaearctic Coleoptera, 6: Chrysomeloidea. Senstrup: Apollo Books; 2010. p. 84-334.

117. Sama G, Rapuzzi P. Una nuova Checklist dei Cerambycidae d'Italia (Insecta Coleoptera Cerambycidae). Quaderno di Studi e Notizie di Storia Naturale della Romagna. 2011; 32: 121-64. Italian.

118. Schmidl J, Bussler H. Rote Liste gefährdeter Bockkäfer (Coleoptera: Cerambycidae) Bayerns. BayLfU. 2003; 166: 150-53. German.

119. Schmitt T, Varga Z. Extra-Mediterranean refugia: the rule and not the exception? Front Zool. 2012; 9(1): 22.

120. Schapker P. The Lepturine Longhorn beetles (Cerambycidae: Lepturinae) of the Pacific Northwest and other stories. Web version 1.1. April, 2017. Availablae at: http://osac.oregonstate.edu/PNW_Lepturinae

121. Seibold S, Brandl R, Buse J, Hothorn T, Schmidl J, Thorn S, Müller J. Association of extinction risk of saproxylic beetles with ecological degradation of forests in Europe. Conserv Biol. 2014; 29(2): 382-90.

122. Serafim R, Maican S. Catalogue of Cerambycidae, Megalopodidae, and Chrysomellidae Coleoptera: Chrysomeloidea) recently entered in the patrimony of "Grigore Antipa" NATION$\mathrm{AL}$ museum of natural history (Bucharest). "Igor Ceianu" collection. Travaux du Muséum National d-Histoire Naturelle „Grogore Antipa“. 2011; 54(2): 425-60.

123. Sláma MEF. Tesaríkoviti - Cerambycidae České republiky a Slovenské republiky (Brouci - Coleoptera). Krhanice: TERCIE PRAHA spol.s r.o.; 1998. p. 383. Czech. 
124. Sláma M, Slámová J. Contribution to the recognition of Greek and Yugoslavian longicorn beetles (Coleoptera, Cerambycidae). Biocosme Mésogéen. 1996; 12(4): 117-42.

125. Solodovnikov IA. Novye i redkie vidy zhestkokrylyh dlia belorusskogo Poozerija i Respubliki Belarus'. Chast' 6. Vestnik VDU 2016; 4(93): 53-67. Russian.

126. Staniulisówna K. Przyczynek do znajomości kózek (Cerambycidae) Wileńszczyzny. Prace Towarzystwa Przyjaciół Nauk w Wilnie. 1939; 13: 374-86. Polish.

127. Stanionis D, Petrikas T. New and rare Coleoptera species in Lithuania. New and Rare for Lithuania Insect Species. 2011; 23: 39-48.

128. Starzyk JR. Morphology, biology and life history of Carilia (=Neogaurotes Pod.) virginea (L.) (Col., Cerambycidae). J Appl Entomol. 1977; 83(1-4): 269-81.

129. Süda I, Miländer G. Eesti Putukate levikuatlas. Siklased - Cerambycidae. Tartu: Eesti Loodusfoto; 1998. p. 88. Estonian.

130. Süda I, Voolma K, Õnap H. Short-term monitoring of fire-adapted Coleoptera in burnt pine forest of northern Estonia. Acta Biologija Universitatis Daugavpiliensis. 2009; 9(1): 43-8.

131. Šablevičius B. Vabzdžiai. Draustinio vabzdžių rūšuu sąrašas. In: Malinauskas V, editor. Kaukinès draustinis. Vilnius: 2000. p. 22-27. Lithuanian.

132. Šablevičius B. New and rare for Lithuania beetle (Coleoptera) species. New and Rare for Lithuania Insect Species. 2003; 15: 11-24.

133. Šablevičius B. New and rare for Lithuania beetle (Coleoptera) species collected in 19882004. New and Rare for Lithuania Insect Species. 2004; 16: 27-31.

134. Šablevičius B. Retų rūšių vabzdžių ir augalų naujos radvietès. Raudoni lapai. 2007; 9: 30-1. Lithuanian.

135. Švácha P. 1989. Cerambycoid larvae of Europe and Soviet Union (Coleoptera, Cearambycoidea). Part III. In Švácha P, Danilevsky ML, editors. Acta Universitatis Carolinae - Biologica. 1989; 32(1988) (1-2): 1-205.

136. Tamutis V. Eighty-two new for Lithuania beetle (Coleoptera) species. New and rare for Lithuania insect species. 2003; 15: 54-62.

137. Tamutis V, Martinaitis K. Grammoptera abdominalis (Stephens, 1831) (Coleoptera: Cerambycidae) - longhorn beetle species new for Lithuanian fauna. Bulletin of the Lithuanian Entomological Society. 2019; 3(31): 38-41.

138. Tamutis V, Tamute B, Ferenca R. A catalogue of Lithuanina beetles (Insecta: Coleoptera). ZooKeys. 2011; 121: 1-494.

139. Tamutis V, Zolubas P. Non-target beetles trapped in Ips typographus L. pheromone traps. Balt J Coleopterol. 2001; 1(1-2): 65-70.

140. Tatarinova AF, Nikitsky NB, Dolgin MM. Fauna Evropeiskogo Severo-Vostoka Rossii. Usachi, ili drovoseki (Coleoptera, Cerambycidae). T. VIII, ch. 2. Moskva-Berlin: DirectMEDIA; 2016. Russian.

141. Telnov D. Checklist of Latvian Beetles (Insecta: Coleoptera). In: Telnov D, editor. Compendium of Latvian Coleoptera. 2004; 1: 1-113.

142. Telnov D, Gailis J, Kalniņ̌s M, Napolov A, Piterāns U, Vilks K, Whitehead PF. Contribution to the knowledge of Latvian Coleoptera. 4. Latvijas Entomologs. 2005; 42: 18-47.

143. Telnov D, Fägerström C, Gailis J, Kalniņš M, Napolov A, Piterāns U, Vilks K. Contribution to the knowledge of Latvian Coleoptera. 5. Latvijas Entomologs. 2006; 43: 78-125.

144. Telnov D, Bukejs A, Gailis J, Kalniņš M. Contribution to the knowledge of Latvian Coleoptera. 7. Latvijas Entomologs. 2008; 46: 47-58.

145. Telnov D, Bukejs A, Gailis J, Kalniņ̌̌ M, Napolov A, Piterāns U, Vilks K. Contribution to the knowledge of Latvian Coleoptera. 8 . Latvijas Entomologs. 2010; 42: 80-91.

146. Telnov D, Bukejs A, Gailis J, Kalniņš M, Kirejtshuk AG, Piterāns U, Savich F. Contribution to the knowledge of Latvian Coleoptera. 10. Latvijas Entomologs. 2016; 53: 89-121. 
147. Tenenbaun S. Przybytki do fauny chrząszczów Polski od roku 1913. Rozprawy i Wiadomości z Muzeum im. Dzieduszyckich. 1923; 7-8: 136-86. Polish.

148. Toshova TB, Subchev M, Abaev V, Vuts J, Imrei Z, Koczor S, Galli Z, Van de Ven R, Tóth M. Responses of Pseudovadonia livida adults to olfactory and visual cues. Bull Insectology. 2016; 69(2): 161-72.

149. Tsinkewich VA, Aleksandrovich OR, Lukashenya MA. Additions to the check list of beetles (Coleoptera) for the Belarussian of the Bialowieza Primeval forest. Balt J Coleopterol. 2005; 5(2): 147-60.

150. Turgut S, Özdikmen H, Cebeci H. Oxymirus cursor and Leptura aurulenta (Coleoptera: Cerambycidae): first records for Turkey. Fla Entomol. 2010; 93(4): 516-18.

151. Twinn PFG, Harding PT. Provisional Atlas of the longhorn beetles (Coleoptera, Cerambycidae) of Britain. Huntingdon: Biological Records Centre; 1999. p. 96.

152. Villiers A. Cerambycidae. Faune des Coléoptères de France. I. Encyclopédie Entomologique, XLII Edition. Paris: Lechevalier; 1978. French.

153. Vincent R, Guillot J. A propos de la biologie lairvaire d'Evodinus (Brachyta) interragationis L. (Coleoptera, Cerambycidae) en Europe occidentale. Revue des Sciences Naturelles d'Auvergne. 1983; 49: 55-62. French.

154. Vitali F. Atlas of the insects of the Grand Duchy of Luxembourg: Coleoptera, Cerambycidae. Ferrantia. 2018; 79: 1-208.

155. Vlasov DV. Fauna usachei (Coleoptera: Cerambycidae) Jaroslavlskoi oblasti. Nauchnye trudy gosudarstvennogo prirodnogo zapovednika "Prisurskii". 2019; 34: 86-114. Russian.
156. Wikars LO. Effect of forest fire and the Ecology of fire adapted species. Acta Universitatis Uppsaliensis. Comprehensive summaries of Uppsala dissertations from the faculty of Sciences and Technology. 1997; 272: 1-35.

157. Wiśniowski B, Baran J. Acmaeops septentrionis (Thomson, 1866) i Drypta dentata (Rossi, 1790) - dwa gatunki chrząszczy (Coleoptera) nowe dla fauny Ovcowskiego parku narodowego. Pracie i Materiały museum im. Prof. Władysława Szafera. 2016; 26: 35-40. Polish.

158. Witkowski ZJ, Król W, Solarz W, editors. Carpathian list of endangered species. ViennaKrakow: WWF and Institute of Nature Conservation, Polish Academy of Sciences; 2003. p. 64.

159.Zajančkauskas P, Pileckis S. Zhestkokrylye (Coleoptera) zapovednika Zhuvintas. In Zajančkauskas P, editor. Zapovednik Zhuvintas. Vilnius: Mintis; 1968. p. 264-82. Russian.

160.Zamoroka AM, Semaniuk DV, Shparyk VYu, Mykyty TV, Skrypnik SV. Toxonomic position of Anastrangalia reyi and A. sequensi (Coleoptera: Cerambycidae) based on molecular and morphological data. Vestnik Zoologii. 2019; 53(3): 209-26.

161.Zandigiacomo P, Cogoi P. Note su Oxymirus cursor (Linnaeus, 1758) in Friuli-Venezia Giulia (Coleoptera Cerambycidae). Gortania Atti del Museo Friulano di Storia Naturale. 2000; 22: 251-60. Italian.

162.Zawadzki Ż. Kózki ziemi Wileńskiej. Spostrzeżenia i notaty. Polskie Pismo Entomologiczne. 1937; 14-15: 281-305. Polish.

163.Žiogas A. Miško entomologija. Kaunas: LŽŪU Leidybinis centras; 1997. p. 271. Lithuanian. 
Vytautas Tamutis, Vitalij Aleksejev

PIETRYČIŲ BALTIJOS REGIONO (LIETUVOS

IR KALININGRADO SRITIES) GRAKŠTENE்-

NŲ (LEPTURINAE LATREILLE, 1802; COLE-

OPTERA: CERAMBYCIDAE) TYRIMAS

Santrauka

Straipsnyje pateikiama pirmoji grakštenènų (Lepturinae Latreille, 1802) pošeimio Coleoptera: Cerambycidae rūšinès sudèties ir paplitimo Pietryčių Baltijos regione analizè. Iš viso buvo išanalizuota daugiau kaip 3000 aptikimo faktu ir daugiau kaip 4600 individų, fiksuotų nuo 1888 iki 2020 metu. Nustatyta, kad minètame regione pošeimiui atstovauja keturioms triboms, 26 gentims priklausančios 38 grakštenėnų rūšys. Faktinès medžiagos, patvirtinančios ankstesnèse publikacijose nurodomų septynių rūšių, tokių kaip Alosterna ingrica (Baeckmann), Brachyta interrogationis russica (Herbst), Euracmaeops marginatus (F.), Gnathacmaeops pratensis (Laichart.), Pachytodes erraticus (Dalman), Rhagium bifasciatum F. ir Stictoleptura v. variicornis (Dalman), buvimą regione, aptikti nepavyko. Straipsnyje taip pat pateikiama informacija apie regione aptiktų grakštenènų rūšių (51 rūšies) paplitimo arealus, išplitimo ir biologijos ypatumus, komentuojami kai kurių rūšių istoriniai tyrimų aspektai. Lokalus 36 rūšių paplitimas laiko ir geografinèse skalèse yra iliustruotas specialiuose žemèlapiuose.

Raktažodžiai: Lepturinae, grakštenėnai, Cerambycidae, Lietuva, Kaliningrado sritis, anotuotas katalogas, faunos analizè 